\title{
MÉTODO DE PLAQUEAMENTO POR GOTAS E OUTROS PARÂMETROS MICROBIOLÓGICOS NA AVALIAÇÃO DA DEGRADAÇÃO DE LODO ATIVADO DE CURTUME EM SOLOS
}

\section{MARCELO CABRAL JAHNEL}

Engenheiro Agrônomo

Orientadora: Profa. Dra. ELKE JURANDY BRAN NOGUEIRA CARDOSO

Tese apresentada à Escola Superior de Agricultura "Luiz de Queiroz", Universidade de São Paulo, para obtenção do título de Doutor em Agronomia, Área de Concentração: Solos e Nutrição de Plantas.

PIRACICABA

Estado de São Paulo - Brasil

Dezembro - 1997 
Dados Internacionais de Catalogação na Publicação (CIP) DIVISĀO DE BIBLIOTECA E DOCUMENTAÇĀO - Campus "Luiz de Queiroz"/USP

Jahnel, Marcelo Cabral

Mécodo de plaqueamento por gotas e outros parâmetros microbiologicos na avaliaçāo da degradaçāo de lodo ativado de curtume em solos / Marcelo Cabral Jahnel. - - Piracicaba, 1997.

79 p. : il.

Tese (doutorado) - Escola Superior de Agricultura Luiz de Queiroz, 1997.

Bibliografia.

1. Contagem de microrganismo 2. Curtume 3. Parâmetro microbiológico 4. Quantificaçào 5. Residuo orgânico 6. Solo 1. Titulo 


\section{MÉTODO DE PLAQUEAMENTO POR GOTAS E OUTROS \\ PARÂMETROS MICROBIOLÓGICOS NA AVALIAÇÃO DA DEGRADAÇÃO DE LODO ATIVADO DE CURTUME EM SOLOS}

MARCELO CABRAL JAHNEL

Aprovada em: 15.01 .1998

Comissão julgadora:

Profa. Dra. Elke Jurandy Bran Nogueira Cardoso

ESALQ/USP

Prof. Dr. Jorge de Castro Kiehl

ESALQ/USP

Prof. Dr. Carlos Clemente Cerri

CENA/USP

Prof. Dr. Wanderley José de Melo

UNESP/JABOTICABAL

Prof. Dr. Augusto Ferreira da Eira

UNESP/BOTUCATU

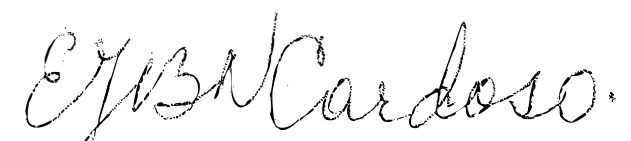

Profa. Dra. Elke Jurandy Bran Nogueira Cardoso Orientadora 
aos pequeninos... 


\section{AGRADECIMENTOS}

À Profa. Dra. Elke Jurandy Bran Nogueira Cardoso, pela proposta do tema, apoio, orientação e amizade.

Aos competentes técnicos de laboratório Denise de Lourdes C. Mescolotti e Fernando Baldesin, pela boa vontade e amizade.

Ao $\mathrm{CNPq}$, pela bolsa de estudos.

À ESALQ e ao Departamento de Ciência do Solo, pelo longo convívio e contribuição à minha formação.

Aos amigos do grupo de trabalho e colegas do curso de Solos e Nutrição de Plantas pelo convívio durante todo este período.

A todos que contribuiram para a realização deste trabalho e para a minha formação científica e pessoal. 


\section{ÍNDICE}

Página

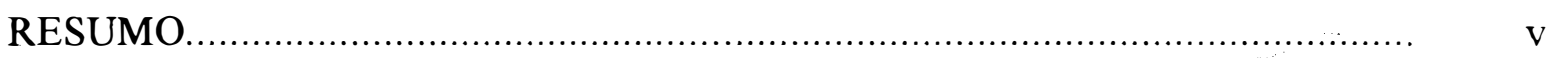

SUMMARY .......................................................................... vii

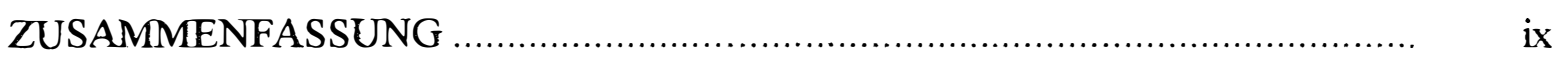

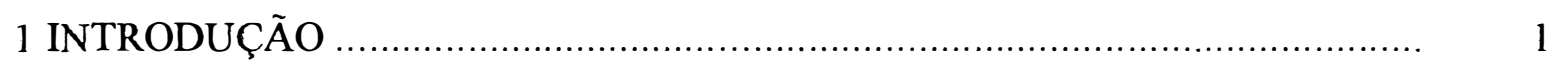

2 REVISÃO DE LITERATURA ........................................................ 3

3 MATERIAL E MÉTODOS .......................................................... 20

3. 1 Contagem de microrganismos do solo pelo método de plaqueamento de gotas .. 20

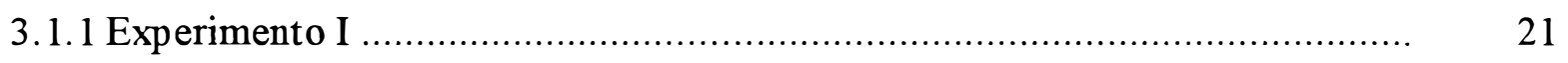

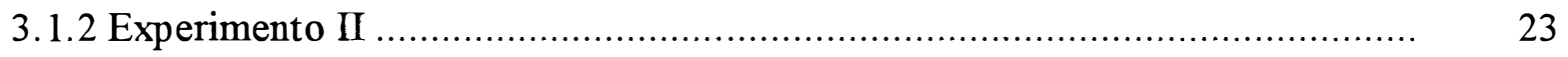

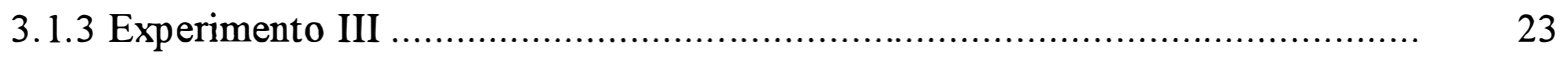

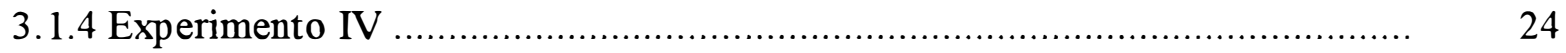

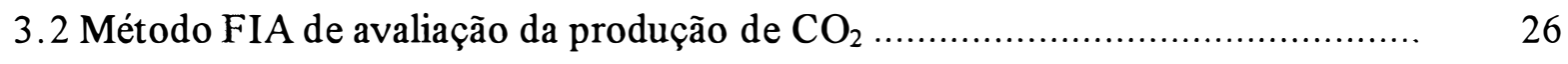

3.3 Avaliação da degradação de lodo de curtume ........................................ 31

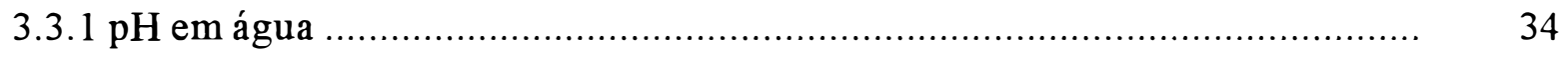

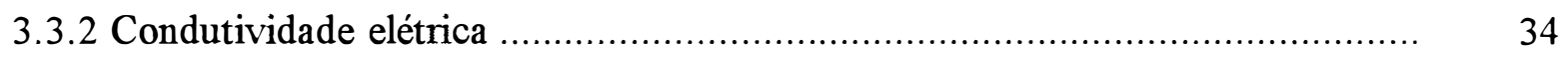

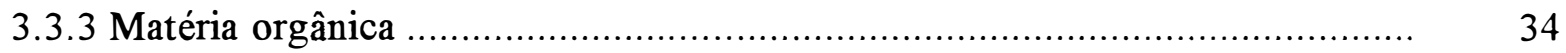

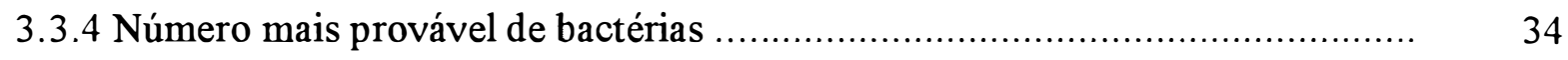

3.3.5 Número mais provável de fungos ........................................... 35

3.3.6 Número mais provável de microrganismos celulolíticos ........................ 35

3.3.7 Número mais provável de microrganismos amonificantes ....................... 35

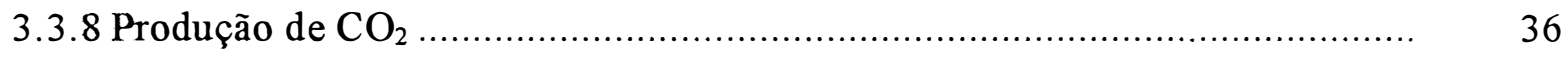




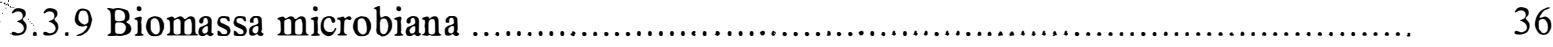

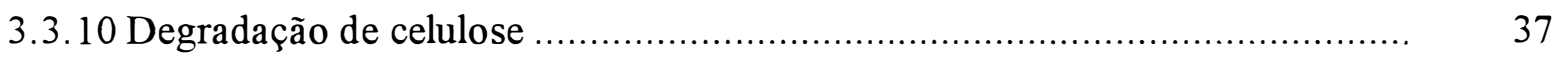

4 RESULTADOS E DISCUSSÃO …......................................................... 38

4.1 Avaliação da metodologia de plaqueamento de gotas ................................... 38

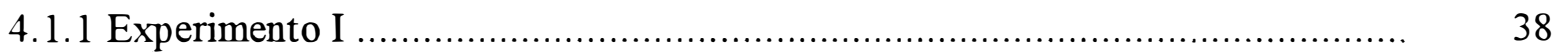

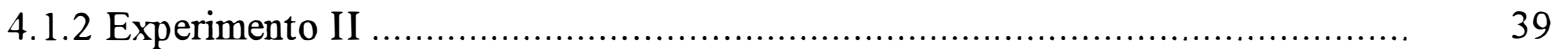

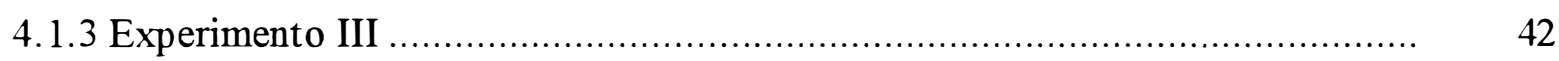

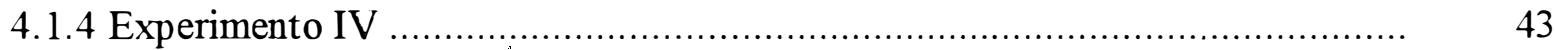

4.2 Estudo da degradação de lodo de curtume .................................................. 46

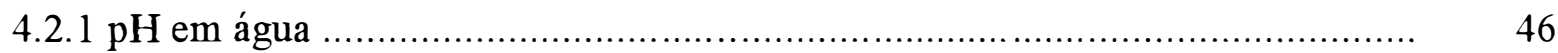

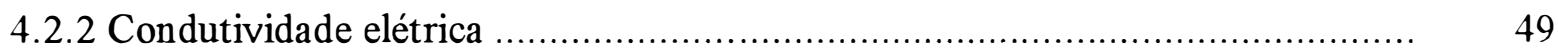

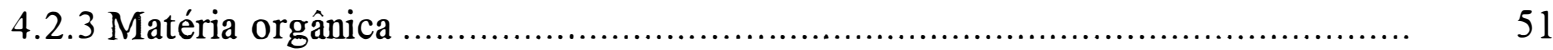

4.2.4 Número mais provável de bactérias ....................................................... 53

4.2.5 Número mais provável de fungos ........................................................ 56

4.2.6 Número mais provável de microrganismos celulolíticos ............................... 58

4.2.7 Número mais provável de microrganismos amonificantes ............................... 60

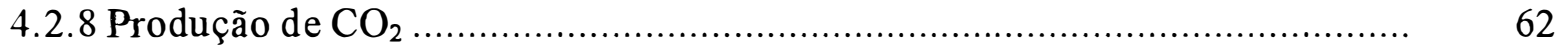

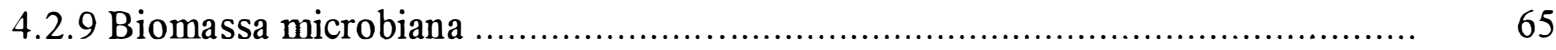

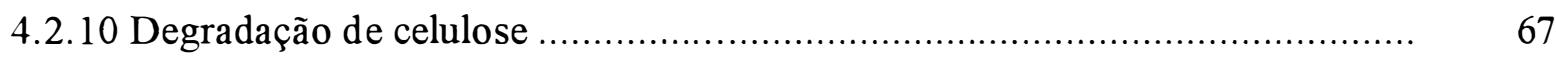

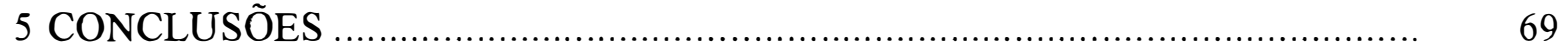

REFERÊNCIAS BIBLIOGRÁFICAS …........................................................ 70 


\section{MÉTOdo de PLAQUEAMENTO POR GOTAS E OUTROS PARÂMETROS MICROBIOLÓGICOS NA AVALIAÇÃO DA DEGRADAÇÃO DE LODO ATIVADO DE CURTUME EM SOLOS}

Candidato: MARCELO CABRAL JAHNEL

Orientadora: Profa. Dra. ELKE J. B. N. CARDOSO

\section{RESUMO}

Parâmetros microbiológicos são ferramentas muito úteis no monitoramento de alterações ambientais causados pela disposição de resíduos orgânicos no solo. No presente trabalho foi desenvolvido um método simplificado de contagem de microrganismos em amostras de solo, em substituição ao método tradicional de diluição e plaqueamento. O método proposto tem como vantagem o menor uso de vidraria, reagentes e trabalho necessário para a sua realização.

A determinação do número mais provável (NMP) de fungos e de bactérias do solo é realizada através da técnica de plaqueamento de gotas. A técnica é apresentada e comparada com o procedimento convencional de contagem de microrganismos em amostras de solo. Foram conduzidos diversos experimentos para verificar a sensibilidade da técnica à adição de diferentes fontes de matéria orgânica e de sais de crômio, e a variações na textura e agregação do solo. A metodologia proposta 
para quantificação do NMP de fungos e bactérias do solo apresentou sensibilidade a variações ambientais e o NMP obtido não diferiu daquele fornecido pela metodologia tradicional de diluição e plaqueamento.

O método de plaqueamento de gotas em placa de Petri, pela sua facilidade e economia de recursos, promete ser uma técnica bastante utilizada no estudo de microrganismos do solo.

Neste trabalho também foi avaliada a viabilidade de utilização da técnica FIA (Flow Injection Analysis, ou em português, Análise Química por Injeção em Fluxo) na avaliação da produção de $\mathrm{CO}_{2}$ proveniente da degradação microbiológica de lodo de esgoto de curtume.

Através do emprego de parâmetros microbiológicos e do método de plaqueamento desenvolvido, foi estudado o efeito da adição de lodo ativado obtido em curtume, em amostras de solo, sobre o número de bactérias e de fungos, com o NMP de microrganismos amonificantes e celulolíticos, biomassa, condutividade elétrica, $\mathrm{pH}$, matéria orgânica e produção de $\mathrm{CO}_{2}$.

O número de fungos, bactérias e dos demais microrganismos estudados foi significativamente maior em todas as doses de lodo diferentes de zero, não ocorrendo efeito prejudicial do composto. A produção de $\mathrm{CO}_{2}$ não diferiu entre os solos estudados, aumentando linearmente com o aumento da dose de lodo e decrescendo de maneira quadrática em relação a tempo. Também foi observado que a adição do lodo ativado de curtume elevou o $\mathrm{pH}$ do solo.

Esta ausência de efeito não é garantia de que o uso de lodo de curtume seja inócuo ao solo pois as técnicas empregadas não são capazes de avaliar alterações qualitativas na variabilidade da microbiota investigada, nem mesmo efeitos causados por aplicações a longo prazo. 


\section{THE AGAR-DROP COUNTING METHOD AND OTHER MICROBIOLOGICAL PARAMETERS FOR THE MEASUREMENT OF THE BIODEGRADATION OF ORGANIC TANNERY RESIDUE}

Candidate: MARCELO CABRAL JAHNEL

Adviser: ELKE J. B. N. CARDOSO

\section{SUMMARY}

Microbial parameters can be valuable tools in the evaluation of environmental changes caused by soil ammendement with organic residues. In this paper a simplified method for counting soil microorganisms is presented, which may substitute for the traditional dilution and plating method with the advantage of requiring less reagents and glassware and being less labor time-consuming.

The evaluation of the most probable number (MPN) of soil fungi and bacteria is done by the agar drop counting technique. This technique was compared to the traditional dilution and plating method, as well as the response to soil ammendements with organic residues or chromium salts was determined in two soils of different texture.

The MPN data obtained by the agar drop counting technique did not differ significantly from those obtained by the traditional method. Therefore, this technique may replace the more laborious and expensive traditional dilution and plating technique. 
The $\mathrm{CO}_{2}$ evolution from soil respirometry was determined by the flow injection analysis (FIA), substituting for the more usual titration method. In one experiment soil was ammended with tannery slime and the MPN of bacteria, fungi, amonifiers and cellulolytic microorganisms, as well as the total microbial biomass, soil electric conductivity, $\mathrm{pH}$, total organic matter and $\mathrm{CO}_{2}$ evolution were determined.

The MPN of all groups studied increased with the increasing rate of tannary slime. $\mathrm{CO}_{2}$ evolution also increased linearly with the level of the added residue and decreased exponencially with incubation time.

The chromium present in the tannery slime showed no negative effect on any of the parameters evaluated. Since the $\mathrm{pH}$ of the soils increased with the level of added residue, this may have decreased the bioavailability of this heavy and potentially toxic metal.

However, these results showed not be interpreted as taking for granted that the tannery residue may be safely used as soil amendement, because there may have been qualitative alterations in the biodiversity of the soil microorganisms, which could not be evaluated by our methods. On the other hand, repeated applications of this residue may cause great chromium accumulation in time, being toxic for microorganisms and plant growth. 


\title{
DIE METHODE DER TROPFENAUFLAGE UND ANDERE MIKROBIOLOGISCHE PARAMETER BEI DER BEWERTUNG DER DEGRADIERUNG VON GERBEREIROHSCHLAMM IN BÖDEN
}

\author{
Kandidat: MARCELO CABRAL JAHNEL
}

Betreuerin: PROF. DR. ELKE J. B. N. CARDOSO

\section{ZUSAMMENFASSUNG}

Bei der Analyse der Auswirkungen auf die Umwelt, die durch Ablagerung organischer Rückstände auf den Boden verursacht werden, stellen mikrobiologische Parameter äusserst nützliche Hilfsmittel dar.

In der vorliegenden Arbeit wurde eine vereinfachte Methode der Zählung von Mikroorganismen entwickelt. Dies geschah mit dem Ziel, die traditionelle Zählmethode von Mikroorganismen in Bodenproben zu ersetzen. Der Vorteil der hier vorgeschlagenen Methode liegt v.a. in der Wirtschaftlichkeit bezüglich der benötigten Ressourcen, z.B. beim Gebrauch von Gläsern, Reagenten und Arbeitsaufwand zur Durchrihrung.

Die Keimzahlbestimmung der Bodenpilze und -bakterien wurde mit Hilfe der Tropfenauflagetechnik durchgeführt. Diese Technik wird zunächst vorgestellt und mit dem konventionellen Vorgehen der Mikroorganismenzählung in Bodenproben 
verglichen. Weiterhin wurden verschiedene Experimente durchgefuihrt, anhand derer die Sensibilität der Technik gegenüber verschiedenen Arten organischen Materials, gegenüber Bodentextur, Tondispersierung sowie gegenüber der Zugabe von Chromsalz überprüft wurde.

Die vorgeschlagene Keimzahlbestimmungstechnik für Bodenpilze und bakterien zeigte dabei Sensibilität gegenüber Veränderungen in der Umwelt und unterschied sich so nicht von der traditionellen Methode.

Aufgrund der Einfachheit und Wirtschaftlichkeit der Ressourcen verspricht die Tropfenauflagemethode in Petrischalen eine häufig genutzte Technik bei der Untersuchung von Bodenmikroorganismen zu werden.

In der vorliegenden Arbeit wurden daneben auch die Anwendungsmöglichkeiten der FIA-Technik bewertet, um die aus der mikrobiologischen Degradation herrührende $\mathrm{CO}_{2}$-Produktion zu untersuchen.

Nachdem sowohl die Zähltechnik für Bakterien und Pilze entwickelt war als auch das Vorgehen für die Mengenbestimmung des $\mathrm{CO}_{2}$ mit Hilfe der FIATechnik genau festgelegt worden war, wurde ein Experiment aufgebaut, welches zum Ziel hatte, die Degradierung eines organischen Rückstandes anhand mikrobiologischer Parameter zu untersuchen. Hierbei kam die neu entwickelte Technik zur Anwendung.

Überprüft wurde dabei die Auswirkung einer Zufubr von aktiviertem Gerbschlamm in Bodenproben auf die Bakterien- und Pilzzahl, wobei diese Daten mit der Keimzahl von amonifizierenden und zellulolytischen Mikroorganismen, der Biomasse, der elektrischen Leitfähigkeit, den $\mathrm{pH}-$ Werten, dem organischen Material und der $\mathrm{CO}_{2}$ Produktion in Beziehung gesetzt wurden.

Die Zahl der Pilze, Bakterien und der übrigen untersuchten Mikroorganismen war signifikant höher in allen Dosierungen des Gerbschlammes, was bedeutet dass keine schädlichen Auswirkungen des Chromiums konstatiert wurden. Die $\mathrm{CO}_{2}$ Produktionen unterschieden sich bei den untersuchten Böden nicht voneinander. Sie stieg linear mit der Steigerung der Dosierung des Schlammes an und nahm im Bezug zur Zeit quadratisch ab. Die Zugabe des Residuums hob den pH-Wert des Bodens, wodurch 
die Biodisponibilität der in diesem Rückstand befindlichen Schwermetalle vorraussichtlich verringert wurde.

Dieses Ausbleiben von Auswirkungen stellt jedoch keine Garantie dafür dar, dass Klärschlamm für den Boden unschädlich ist, denn die angewandten Tecliniken sind weder geeignet, Änderungen in der qualitativen Variabilität der untersuchten Mikroorganismen zu bewerten, noch Auswirkungen zu erkennen, die durch Langzeitauftragung von Klärschlamm auf den Boden zustande kommen. 


\section{INTRODUÇÃO}

A manutenção da fertilidade do solo depende da presença e da atividade de microrganismos que desempenham papel fundamental na ciclagem da maior parte dos nutrientes. Alterações na composição e atividade da microbiota do solo, em função da presença de compostos tóxicos ou xenobióticos, poderá levar a alterações na disponibilidade de nutrientes para plantas.

Lodos de estações de tratamento de resíduos tem sido aplicados em solos agrícolas como forma de disposição final ou mesmo como fonte de nutrientes e de matéria orgânica. No entanto, a grande maioria dos lodos, além de nutrientes, contêm quantidades expressivas de substâncias potencialmente tóxicas, entre eles os metais pesados. Enquanto a maior parte dos nutrientes adicionados ao solo está sujeita à remoção através de lixiviação e absorção pelas culturas, os metais pesados permanecem no solo por um período muito maior de tempo.

Muitos trabalhos avaliam a qualidade de resíduos orgânicos sob o ponto de vista de nutrição de plantas, no entanto, o estudo dos efeitos de compostos potencialmente tóxicos sobre a atividade da microbiota do solo auxilia na avaliação dos riscos ambientais e alterações na fertilidade que estes resíduos possam causar.

A quantificação do número de microrganismos é uma forma de conhecer a ação que compostos potencialmente tóxicos exercem sobre a microbiota do solo. No entanto, a quantificação de microrganismos, além de demandar quantidades expressivas de reagentes, é uma prática extremamente trabalhosa, dificultando a realização de grande número de determinações.

Outra forma de avaliar os efeitos de compostos tóxicos sobre a atividade microbiana é realizada através da quantificação da produção de $\mathrm{CO}_{2}$, ou seja, 
por respirometria. A fim de avaliar a produção de $\mathrm{CO}_{2}$ em intervalos de tempo menores do que 24 horas e com resultados mais precisos do que o procedimento tradicionalmente utilizado de titulação, foi avaliada neste trabalho a viabilidade da utilização da técnica FIA (Flow Injection Analysis) de quantificação de $\mathrm{CO}_{2}$, proveniente da degradação microbiológica de resíduos orgânicos.

Combinando atividade microbiológica e estimativas de número de microrganismos, obtêm-se indicadores mais sensiveis da poluição do solo do que aqueles que seriam obtidos através da avaliação de um único parâmetro (Brookes, 1995). Desta maneira, foram avaliados os resultados de quantificação de microrganismos, obtidos com a técnica de plaqueamento em gotas com os demais parâmetros microbiológicos durante o processo de degradação de resíduo proveniente de estação de tratamento de indústria de processamento de couro.

Portanto, os principais objetivos deste trabalho foram: desenvolver um método simplificado de contagem de microrganismos, estudar o método FIA de avaliação da produção de $\mathrm{CO}_{2}$ proveniente da degradação microbiológica e estudar a degradação de resíduo orgânico proveniente de indústria de processamento de couro. 


\section{REVISÃO DE LITERATURA}

Parâmetros microbiológicos são ferramentas bastante úteis no monitoramento da poluição do solo. No entanto, quando estes parâmetros são utilizados individualmente, não oferecem informações adequadas da ação de compostos xenobióticos sobre a comunidade de microrganismos do solo.

Atividades microbiológicas tais como respiração, fixação biológica do nitrogênio, mineralização de compostos orgânicos, atividade enzimática e biomassa microbiana do solo podem ser quantificadas através de técnicas bastante conhecidas. Combinando atividade microbiológica e estimativas de número de microrganismos, obtêm-se indicadores mais sensíveis da poluição do solo do que aqueles que seriam obtidos através da avaliação de um único parâmetro. Com esta abordagem, é possível avaliar a alteração de um ambiente natural sem a necessidade de se recorrer a longos e dispendiosos experimentos de campo (Brookes, 1995).

A indústria curtumeira, apesar da grande importância econômica, apresenta elevado potencial poluidor devido à geração de grandes quantidades de resíduos, caracterizados por elevada carga orgânica, alto teor de fenóis, sulfetos e metais pesados, principalmente o crômio. Estimativas da produção de resíduo de curtume no Brasil são da ordem de $270.10^{3} \mathrm{t} \mathrm{ano}^{-1}$ de resíduos sólidos com elevado potencial poluidor (Tedesco \& Gianello, 1997).

Estudos visando a utilização agrícola dos resíduos de curtume têm sido realizados principalmente com o lodo resultante do tratamento de efluentes. No momento, pouco se conhece sobre a quantidade de resíduo orgânico de curtume que pode ser aplicado a solo sem que ocorra prejuízos ambientais (Castilhos et al., 1997). 
Lodo de esgoto e composto de resíduos urbanos, bem como lodo proveniente do fundo de rios, possuem, de forma geral, quantidade significativa de matéria orgânica, bem como cálcio e outros macro e microelementos. Desta maneira, estes resíduos podem ser utilizados como melhoradores de solo ou como fertilizantes. A sua utilização, no entanto, é limitada pelos teores que estes resíduos possuem em componentes orgânicos e inorgânicos tóxicos. Além disto, lodo de esgoto com baixos teores de sólidos totais pode conter bactérias patogênicas, vírus e ovos ou larvas de vermes ou insetos. Lodo de esgoto possui matéria orgânica $\left(50-750 \mathrm{~g} \mathrm{dm}^{-3}\right)$ como componente principal da matéria seca. Contém, ainda, quantidades consideráveis dos macronutrientes nitrogênio $\left(4-120 \mathrm{~g} \mathrm{dm}^{-3}\right)$, fósforo $\left(2-50 \mathrm{~g} \mathrm{dm}^{-3}\right)$, potássio $(0,3-70 \mathrm{~g}$ $\left.\mathrm{dm}^{-3}\right)$, magnésio $\left(0,5-35 \mathrm{~g} \mathrm{dm}^{-3}\right)$ e cálcio $\left(1-350 \mathrm{~g} \mathrm{dm}^{-3}\right)$. Além destes nutrientes o lodo de esgoto contém uma série de compostos tóxicos, principalmente os metais pesados chumbo, cádmio, crômio, níquel e mercúrio, bem como os micronutrientes boro, cobre e zinco, que muitas vezes se encontram em concentrações extremamente elevadas a ponto de tornar a utilização do lodo problemática. Dependendo da origem do lodo ocorrem variações consideráveis na sua composição (Scheffer \& Schachtschabel, 1992).

Pela normalização da Associação Brasileira de Normas Técnicas (ABNT, 1987), o lodo de esgoto é considerado resíduo sólido, sendo definido da seguinte forma: 'Resíduos nos estados sólido e semi-sólido, que resultam da comunidade de origem: industrial, doméstica, hospitalar, comercial, agrícola e de serviços de varrição. Ficam incluídos nesta definição os lodos provenientes de sistemas de tratamento de água, aqueles gerados em equipamentos e instalações de controle de poluição, bem como determinados líquidos cujas particularidades tornem inviável o seu lançamento na rede pública de esgoto ou corpos de água, ou exijam para isso soluções técnicas e economicamente viáveis face à melhor tecnologia disponível." De forma mais simples pode ser dito que lodo de esgoto é o lodo proveniente do tratamento de esgoto em estação de tratamento. 
Uma definição mais simples, é a do ministério do meio ambiente alemão que define lodo de esgoto como resíduo tóxico contendo nutrientes (Umweltbundesamt ${ }^{1}$, citado por Kretzschmar, 1992).

Lodo de esgoto é um resíduo extremamente aquoso e/ou pastoso, constitui-se basicamente de $70 \%$ de matéria orgânica e 30\% de minerais. Considera-se ainda, como lodo de esgoto, o lodo proveniente de estação de tratamento que recebeu calcário para higienização ou mesmo para ser utilizado como condicionador de solos (Kretzschmar, 1992).

Em decorrência da presença de quantidades apreciáveis de matéria orgânica, o lodo de esgoto beneficia as plantas cultivadas por fornecer macro e micronutrientes e aumentar a capacidade de retenção de água do solo, auxiliando ainda na redução de processos erosivos, principalmente em áreas de relevo declivoso. A utilização de lodo de esgoto na agricultura, no entanto, não deve causar danos ao solo, à vegetação, aos animais e à espécie humana (Scheffer \& Schachtschabel, 1992).

A aplicação de lodo proveniente de estações de tratamento de resíduos no solo é uma forma de imitar a natureza no processo de reciclagem de nutrientes. Lodo de esgoto, além de ser uma fonte de nutrientes para plantas, contém grande quantidade de matéria orgânica, a qual funciona como condicionador do solo.

Limites máximos têm sido estabelecidos para garantir que a acumulação de elementos potencialmente tóxicos no solo esteja abaixo das concentrações que causem efeitos adversos em plantas ou em animais, bem como nos seres humanos que os consomem. No entanto, alguns estudos têm mostrado que a aplicação de lodo ao solo, abaixo dos valores permitidos para metais pesados, tem provocado efeitos desfavoráveis sobre os microrganismos, especialmente após a interrupção da aplicação, quando o teor de matéria orgânica decresce (Brookes \& McGrath, 1984).

É sabido que o lodo de esgoto obtido de áreas industriais contém invariavelmente quantidades consideráveis de metais potencialmente tóxicos, tais como $\mathrm{Cu}, \mathrm{Zn}, \mathrm{Ni}, \mathrm{Cd}, \mathrm{Pb}$ e $\mathrm{Cr}$. Estes metais são adsorvidos na superfície dos colóides do solo,

\footnotetext{
${ }^{1}$ UMWELTBUNDESAMT. Klärschlammverordnung (AbfklärV), Berlim, 1982.
} 
acumulando-se com as sucessivas aplicações de lodo (Brookes \& Mcgrath, 1984; Scheffer \& Schachtschabel, 1992).

Segundo Heckman et al., (1987), enquanto a maior parte dos nutrientes adicionados com o lodo é removida pelas culturas ou é lixiviada, os metais pesados permanecem no solo por muito mais tempo. Esses autores salientam que estudos de longa duração mostram que o cádmio ainda foi absorvido por plantas, mesmo depois de 20 anos da última aplicação de lodo no solo.

Outros autores também avaliaram a utilização do lodo de esgoto como fonte de nutrientes e seus efeitos sobre a atividade de microrganismos do solo (Reber \& Fließbach, 1991; Smith \& Hadley, 1992). Com composição extremamente variável e contendo elevados teores de metais pesados, a contaminação do solo pelo uso do lodo de esgoto causa efeitos fitotóxicos e aumenta a entrada de metais pesados na cadeia alimentar (Korcak et al., 1979; Fließbach et al., 1994).

Deve-se lembrar, ainda, que o lodo de esgoto contém bactérias patogênicas, e a sua utilização deve levar em conta os aspectos sanitários. Desta maneira não se recomenda a aplicação de lodo de esgoto em campos de produção de forragens, legumes e frutas (Scheffer \& Schachtschabel, 1992).

Segundo Alloway (1990), o termo metal pesado, embora não facilmente definivel, é amplamente utilizado para um grupo de metais e metalóides associado com poluição e toxicidade, incluindo também alguns microelementos, os quais são essenciais para os organismos vivos, tais como $\mathrm{Co}, \mathrm{Cu}, \mathrm{Mn}$, Se e $\mathrm{Zn}$. Segundo este autor, uma alternativa para sua denominação seria o uso do termo metal tóxico. Esta definição, no entanto, seria aplicável somente aos elementos não essenciais, tais como $\mathrm{Pb}$, $\mathrm{Cd}, \mathrm{Hg}, \mathrm{As}$ e U e não seria apropriada para elementos biologicamente essenciais. Uma alternativa, seria o uso do termo elemento traço em substituição ao termo metal pesado, mas esta opção ainda não é empregada de forma usual.

O termo poluição, em alguns casos, é mais fácil de ser definido do que o termo metal pesado, mas também é facilmente confundido com o termo contaminação. Segundo Alloway (1990) os termos contaminação e poluição são freqüentemente 
confundidos e usados indistintamente, embora o termo poluição tenha uma conotação pejorativa.

Metais pesados são componentes inerentes ao solo. No entanto, grande parte dos metais pesados provenientes da indústria, áreas urbanas e do trânsito de veículos acaba, cedo ou tarde, atingindo o solo através de poeira, chuva ácida e principalmente pela deposição de composto de lixo e de diferentes tipos de lodo (Hattori, 1992).

Apesar de o teor médio de metais pesados encontrado em muitos locais ainda ser baixo, a adição de resíduos contendo estes metais pode causar efeito prejudicial sobre plantas (Sposito et al., 1982; Eltrop et al., 1991; Brown \& Brinkmann, 1992) e sobre a atividade de microrganismos do solo (Ross et al., 1981; Lindemann et al., 1984; Hattori, 1992; Fließbach et al., 1994), com reflexos na ciclagem de nutrientes e na fertilidade (Bollag \& Barabasz, 1979). Enquanto que o esgoto e as emissões de gás podem ser purificados, os metais pesados adicionados ao solo não podem, ou dificilmente poderão ser removidos (Brüne, 1987).

A mobilidade e a biodisponibilidade de metais pesados potencialmente tóxicos está intimamente relacionada com as transformações químicas associadas às condições ambientais existentes no solo. $\mathrm{O}$ efeito de metais pesados depende basicamente da CTC e do pH do solo (Kabata-Pendias \& Pendias, 1986).

Bruemmer et al. (1988), estudando o comportamento de $\mathrm{Ni}, \mathrm{Zn}$ e Cd em solos ricos em goetita, verificaram que o processo de adsorsão de metais varia em função do pH, da temperatura e do tempo de reação. Lake et al. (1984), fazendo estudos de especiação em solos, verificaram que os metais pesados estão predominantemente associados à fase sólida, e as espécies solúveis e trocáveis geralmente representam menos de $10 \%$ do total de metais presentes no solo.

Chang et al. (1984), trabalhando com um Alfisol e um solo rico em carbonato, verificaram que boa parte dos metais permanece adsorvida na fração carbonato e parte na fração orgânica. Estudando o efeito da adição de lodo sobre a cultura de cevada, perceberam que a absorção de $\mathrm{Cd}$ e $\mathrm{Zn}$ foi muito maior nos tratamentos que receberam lodo do que naqueles que não receberam. A absorção destes 
elementos foi alta nas primeiras fases de desenvolvimento da cultura e diminuiu progressivamente com a idade da planta.

Possivelmente crômio não seja um elemento essencial para plantas, mas o é para a espécie humana e para animais, participando do metabolismo da glicose e da estrutura de proteínas e ácidos nucleicos, além de ativar algumas enzimas (Bartlett \& Kimble, 1976a; Scheffer \& Schachtschabel, 1992; Prokisch et al., 1995). Na natureza, o crômio ocorre principalmente na forma trivalente, e o principal mineral rico em crômio é a cromita $\left(\mathrm{FeOCr}_{2} \mathrm{O}_{3}\right)$. No entanto, existem minerais contendo $\mathrm{Cr}$ (VI) tais como o $\mathrm{PbCrO}_{4}$. No solo o crômio pode se encontrar nos dois graus de oxidação, dependendo do potencial redox e do valor de $\mathrm{pH}$, apresentando-se nas seguintes formas: $\mathrm{Cr}^{3+}, \mathrm{Cr}(\mathrm{OH})_{3}$ e eventualmente como $\mathrm{Cr}_{2} \mathrm{O}_{3} . \mathrm{xH}_{2} \mathrm{O}$, bem como $\mathrm{HCrO}_{4}{ }^{-}$e $\mathrm{CrO}_{4}{ }^{2-}$.

A produção mundial de crômio em 1980 era da ordem de $2,8 \times 10^{6}$ t ao ano (Scheffer \& Schachtschabel, 1992). O crômio é utilizado em vários processos industriais, tais como metalurgia, produção de tintas, vidros, cerâmica e na indústria do couro. Freqüentemente são encontrados teores elevados de crômio em resíduos orgânicos provenientes destas indústrias (Ross et al., 1981; Scheffer \& Schachtschabel, 1992).

A adição de matéria orgânica, que funciona como doador de elétrons, promove a redução de compostos contendo $\mathrm{Cr}(\mathrm{VI})$, auxiliando na recuperação de solos contaminados com este metal. Com o aumento do valor $\mathrm{pH}$, o crômio reduzido é então imobilizado na forma de complexos de óxido de ferro. A reação inversa também é possivel em solos bem drenados e com baixos teores de matéria orgânica (Bartlett \& Kimble, 1976a; Scheffer \& Schachtschabel, 1992). Na presença de Al ocorre a precipitação do $\mathrm{Cr}(\mathrm{VI})$, quando o $\mathrm{pH}$ se encontra entre 4 e 5 . O crômio (VI) passa a ser completamente insolúvel próximo a $\mathrm{pH}$ 6, e aumenta sua solubilidade novamente quando o $\mathrm{pH}$ atinge valores superiores a 8 . A redução do $\mathrm{Cr}(\mathrm{VI})$ aumenta o valor do $\mathrm{pH}$ da solução do solo (Bartlett \& Kimble, 1976b; Prokisch et al., 1995).

O Cr (III) na forma inorgânica não apresenta mobilidade no solo e, portanto, não é absorvido por microrganismos, provavelmente devido à baixa 
solubilidade e por formar hidróxidos em valores de $\mathrm{pH}$ próximos à neutralidade (Bartlett \& Kimble, 1976b; Ross et al., 1981).

O crômio não penetra facilmente através da membrana celular de raizes e somente uma pequena porção é transportada para o interior da planta. Desta maneira, a concentração de $\mathrm{Cr}$ na planta decresce na seguinte ordem: raiz, folhas, semente, fruto. Mesmo uma aplicação relativamente elevada de lodo de esgoto no solo aumenta muito pouco os teores de crômio em plantas. Possivelmente o efeito tóxico de $\mathrm{Cr}$ (VI) em plantas se deva à oxidação de componentes celulares, resultante da sua redução no interior da célula (Ross et al., 1981).

Efeitos tóxicos de compostos de $\mathrm{Cr}(\mathrm{III})$ e $\mathrm{Cr}$ metálico são dificeis de ser determinados; já compostos de $\operatorname{Cr}(\mathrm{VI})$ são 10 a 100 vezes mais tóxicos e podem provocar toxicidade em seres humanos (Scheffer \& Schachtschabel, 1992). Ross et al. (1981) não observaram toxicidade de Cr (III) para microrganismos. Acreditam, no entanto, que não se deve considerar que a adição de $\mathrm{Cr}$ (III) seja inócua.

Em valores de $\mathrm{pH}$ menores do que 4,5, o crômio se encontra na forma do íon $\mathrm{Cr}^{3+}$, sendo fortemente adsorvido a o óxido de ferro na forma de cátion trivalente. O teor de Cr na solução de solos levemente ácidos a neutros situa-se aproximadamente entre 0,6 e $40 \mu \mathrm{g} \mathrm{L}^{-1}$ e, em pH menor do que 4 atinge valores de $400 \mu \mathrm{g} \mathrm{L}^{-1}$. Na solução do solo, o crômio encontra-se na forma de complexo associado com carbonato e compostos orgânicos de baixa solubilidade, mobilidade e disponibilidade.

Em solos ácidos e pobres em nutrientes ocorre um predomínio de fungos e algas clorofiladas, enquanto bactérias e actinomicetos predominam em solos ligeiramente ácidos até ligeiramente alcalinos e mais ricos em nutrientes.

Os organismos do solo participam da mineralização de substâncias orgânicas, transformando-as em compostos inorgânicos, tornando disponiveis os nutrientes para as plantas e liberando $\mathrm{CO}_{2}$ que será utilizado pela vegetação na produção de novas substâncias orgânicas. Do $\mathrm{CO}_{2}$ produzido no solo, em torno de $70 \%$ são resultantes do processo respiratório de microrganismos e os $30 \%$ restantes provêm da respiração de raízes e da mesofauna. 
As bactérias são os organismos do solo mais importantes nas transformações de resíduos. São microscópicas $(0,5-3 \mu \mathrm{m} \phi)$, procariotos e de forma geral aclorofiladas, com multiplicação através de divisão celular (Brandão, 1992). Embora as bactérias constituam o grupo de maior número no solo, representam apenas $25 \%$ da biomassa total de solos agrícolas (Siqueira \& Franco 1988).

Existem no solo diversas espécies de bactérias que obtém a sua energia de diferentes fontes, tais como: bactérias capazes de degradar carboidratos (Cellulomonas, Chlostridium), bactérias degradadoras de proteínas e amonificantes (Bacillus mycoides), bactérias nitrificantes (Nitrosomonas, Nitrobacter), denitrificadoras (Pseudomonas, Achromobacter), fixadoras de nitrogênio (Chlostridium, Enterobacter), bactérias do enxofre (Thiobacillus, Beggiatoa) e bactérias do ferro (Ferribacterium, Ferrobacillus) (Trautz, 1992).

Os fungos, juntamente com os actinomicetos e outras bactérias degradam celulose, lignina, proteína e outros compostos, participando do processo de humificação. Os fungos predominam em solos com reação ácida, pois neste ambiente não sofrem competição de bactérias e actinomicetos que são capazes de produzir substâncias tóxicas ou inibidoras de crescimento.

Muitos organismos podem sobreviver durante longos períodos com disponibilidade inadequada de água, através de formas de resistência (inativas) como cistos (bactérias e protozoários), esporos (fungos) ou como células vegetativas (Azotobacter, Nitrosomonas). Importante para os organismos do solo é a proporção entre água e oxigênio. Para muitos organismos, as melhores condições de desenvolvimento ocorrem em solos arenosos, em torno da capacidade de campo, e em solos argilosos, em torno da metade da capacidade de campo. As características do solo, tais como temperatura, $\mathrm{pH}$, umidade, teor de oxigênio e nutrientes, irão determinar a composição da comunidade biológica do solo, qualitativa e quantitativamente (Brandão, 1992).

A temperatura ideal para a maioria dos organismos do solo está entre $10^{\circ} \mathrm{C}$ e $30^{\circ} \mathrm{C}$. A influência da temperatura na composição da comunidade microbiana do solo pode ser demostrada quando se comparam amostras de solo de diferentes regiões. 
Enquanto nas regiões mais quentes predominam espécies de Aspergillus, nas temperadas ocorre a predominância de espécies de Penicillium (Trautz, 1992).

Quando o solo recebe grande aporte de matéria orgânica biologicamente degradável, ocorre um aumento no número de microrganismos (Smith, 1991), levando a imobilização de nutrientes para a síntese de biomassa, funcionando como mecanismo de proteção contra a perda de nutrientes durante o processo de lixiviação. Por outro lado, a imobilização de nutrientes pode, ao mesmo tempo, causar deficiência de nutrientes em plantas. Como resposta às alterações da atividade biológica do solo ocorre também aumento na concentração de $\mathrm{CO}_{2}$ no ar do solo, decorrente da respiração de organismos e de raízes de plantas.

A salinização do solo, avaliada através da condutividade elétrica, não ocorre somente através de água de irrigação ou pelo uso de fertilizantes minerais; ela também pode ocorrer através do uso de resíduos orgânicos ricos em sais, como são os lodos provenientes do processamento de couro. O sal adicionado durante a fase de preparação das peles aumenta consideravelmente a saturação das cargas do solo com sódio, com conseqüente efeito sobre a estabilidade de agregados, volume de poros e plasticidade do solo.

As culturas sensíveis à salinidade sofrem progressiva redução do crescimento e da produção à medida que a concentração salina aumenta. Os danos causados pela salinidade são devidos principalmente à elevada pressão osmótica na solução do solo, reduzindo a disponibilidade de água e causando perturbações nutricionais às plantas (Cruciani, 1983). Nos solos de clima úmido, a concentração de sais é normalmente baixa em função das elevadas precipitações atmosféricas, e só se eleva em função do uso de fertilizantes minerais, da irrigação com água de baixa qualidade ou pela mineralização de matéria orgânica.

Os microrganismos possuem grande capacidade de regeneração, e os diferentes componentes da microbiota do solo são participantes fundamentais da fertilidade do solo. Desta maneira, deve-se garantir que práticas agrícolas, como a adição de lodo de esgoto, não causem danos duradouros na comunidade do solo (Trautz, 1992). 
Por participarem de diversos processos que influenciam a fertilidade, os microrganismos são de fundamental importância para a produtividade de solos cultivados.

O lodo de esgoto, além de conter matéria orgânica e nutrientes, possui ainda elementos potencialmente tóxicos, tais como metais pesados, que podem se acumular na zona cultivada do solo (Doelman \& Haanstra, 1979; Smith, 1991).

Smith (1991) acredita que as informações disponíveis dos efeitos de metais pesados sobre os processos microbianos são insuficientes para avaliar o impacto da aplicação de resíduos orgânicos, ricos em metais, na fertilidade do solo. No entanto, afirma que a comunidade microbiana do solo tem uma evidente capacidade adaptativa em relação a compostos potencialmente tóxicos, de tal maneira que mesmo em solos extremamente contaminados, os processos microbiológicos essenciais são mantidos. Segundo este autor, existem claras evidências de que metais pesados afetam os processos microbiológicos do solo mas, em concentrações superiores aos atuais limites estabelecidos pelas agências de proteção ambiental.

Alguns autores verificaram que os fungos do solo são muito mais resistentes do que as bactérias aos metais pesados (Beck, 1981; Maliszewska et al., 1985; Hiroki, 1992; Fließbach et al., 1994) e que os processos de desenvolvimento de resistência são complexos e poucos conhecidos (Smith, 1991), não ocorrendo rapidamente, e sim, após longo período de tempo (Doelman \& Haanstra, 1984).

Metais pesados afetam o crescimento, a morfologia e o metabolismo de microrganismos através de distúrbios funcionais, desnaturação de proteínas e destruição da integridade de membranas celulares. Como conseqüência, a poluição por metais pesados pode reduzir o tamanho e a atividade biológica da biomassa microbiana (Brookes \& Mcgrath, 1984).

A avaliação de impactos de metais pesados sobre microrganismos do solo através de técnicas de plaqueamento promove seleção para determinado grupo de microrganismos, pois somente um número relativamente pequeno de espécies da comunidade microbiana do solo é capaz de se desenvolver em meio de cultura simples. Segundo Brookes \& McGrath, (1984), deve-se levar ainda em consideração que a 
contagem em placas avalia somente o número de microrganismos e não a biomassa da comunidade microbiana.

A biomassa microbiana avaliada pelo método fumigação-incubação pressupõe que o agente fumigante, matando as células da comunidade microbiológica da amostra de solo, torna-as susceptíveis à decomposição pela nova comunidade microbiológica proveniente da recolonização. No entanto, conforme Jenkinson \& Powlson (1976), o método de fumigação-incubação pode estimar incorretamente a biomassa microbiana se os solos são bem drenados ou receberam recentemente a adição de substrato fresco ou mesmo se o valor $\mathrm{pH}$ é muito menor do que 4,5.

Brookes \& McGrath, (1984), compararam a quantidade de biomassa total em solos fertilizados com esterco de curral e com resíduos orgânicos contaminados com metais pesados, e observaram a ocorrência de correlação positiva entre biomassa microbiana e carbono total apenas nos solos que receberam esterco de curral. A ausência de correlação em solos que receberam lodo ou composto de lodo contaminado foi atribuída a o efeito tóxico do metal presente no lodo sobre a comunidade microbiana do solo. Salientam, ainda, que a redução da biomassa em solos contendo metais é perceptível mesmo após 20 anos da última aplicação de lodo.

Brookes et al. (1986) afirmaram que a biomassa microbiana do solo é o agente responsável pela degradação da matéria orgânica, e geralmente aumenta quando resíduos orgânicos são incorporados ao solo. Estes autores colocam em dúvida os baixos valores de biomassa encontrados em solos ricos em metais pesados, pois acreditam ser resultado da interferência dos metais sobre o método de análise. Para avaliar o efeito de metais pesados sobre o método de quantificação da biomassa, utilizaram quantidades conhecidas de extrato de levedura enriquecidas com metais pesados, observando que a presença de metais não interfere nos resultados. O trabalho demonstra que a decomposição da biomassa nativa do solo ou do material microbiológico adicionado após a fumigação foi pouco afetado pela presença de metais, concluindo que a técnica de fumigação-incubação é um procedimento adequado para avaliar a biomassa em solos contaminados com teores moderados de metais pesados. 
Em muitos dos estudos realizados para verificar o efeito de metais pesados sobre microrganismos do solo freqüentemente tem sido empregados metais pesados na forma de sais. Este procedimento com freqüência resulta em efeito inibitório sobre a taxa de respiração (Chang \& Broadbent, 1981), biomassa (Smith, 1991; Fließbach et al., 1994; Chander et al., 1995; Valsecchi et al., 1995), mineralização (Rother et al., 1982; Ueda et al. 1988a), fixação de nitrogênio (Lorenz et al., 1992), nitrificação (Bollag \& Barabasz, 1979), contagem de microrganismos (Ross et al., 1981; Olson \& Thornton, 1982; Ueda et al., 1988b; Hiroki, 1992) e atividade enzimática (Smith, 1991). No entanto, a aplicação de lodo de esgoto geralmente aumenta a atividade de microrganismos do solo pelo aumento no teor de matéria orgânica, mesmo quando apresenta teores elevados de metais pesados.

É muito dificil determinar a toxicidade de metais pesados para microrganismos, pois o efeito tóxico dos metais é função das relações de concentração existentes na solução do solo e não da concentração total. Os efeitos são determinados pela reação do solo, relação entre os nutrientes, CTC, bem como pelo sinergismo entre estes fatores (Schimming, 1992). Deve-se considerar que a influência dos metais pesados sobre a atividade dos microrganismos do solo varia com o tipo de metal e com as características do solo (Hattori, 1992).

Diversos parâmetros microbiológicos têm sido utilizados para avaliar os impactos ambientais causados pela aplicação de resíduos no solo. No entanto, os resultados obtidos ainda são polêmicos. Brendecke et al. (1993), trabalhando em solos de deserto, não observaram redução na atividade de microrganismos após quatro anos de aplicação de lodo de esgoto. Esta avaliação foi realizada através de contagens de bactérias, fungos e actinomicetos em placas e da quantificação da atividade da desidrogenase e da produção de $\mathrm{CO}_{2}$. Esses autores concluem que a aplicação de lodo de esgoto não reduz a fertilidade do solo por não prejudicar a atividade de microrganismos.

Witter et al. (1994), em carta ao editor da revista Soil Biology \& Biochemistry, onde o trabalho de Brendecke et al. (1993) foi publicado, criticam esses autores, afirmando que o teor de metais existente no lodo estudado era muito baixo e que os parâmetros microbiológicos escolhidos não foram suficientemente sensíveis. 
Acrescentam que a ausência de efeitos prejudiciais nos primeiros anos de aplicação não constitui garantia de que efeitos prejudiciais não venham a ocorrer posteriormente, preferindo não recomendar a aplicação de lodo de esgoto no solo.

Pepper et al. (1994), também criticando o mesmo trabalho, afirmaram que o solo de deserto onde foi montado o experimento apresentava valor de $\mathrm{pH}$ elevado e baixo teor de matéria orgânica e, portanto, haveria menor disponibilidade de metais neste solo quando comparado a solos com baixo valor de $\mathrm{pH}$. Afirmam que o lodo contendo metais será menos tóxico se aplicado em solo de deserto do que se aplicado na mesma quantidade a um solo com reação ácida.

Percebe-se nesta troca de correspondências, que a utilização de parâmetros microbiológicos na avaliação de impactos ambientais pode justificar a adoção ou não da prática de disposição do lodo de esgoto no solo.

O que se sabe, no entanto, é que elevadas concentrações de metais pesados produzem diminuição no número de indivíduos, alteração na composição de espécies ou mesmo na capacidade metabólica de microrganismos, com freqüente desenvolvimento de organismos resistentes. Trabalho de Olson \& Thornton (1982) mostra que o número de organismos resistentes ao cádmio aumenta com o grau de contaminação do solo dos quais eles provêm.

Redução da biomassa e da atividade biológica de microrganismos pela ação de metais pesados foi observada por diversos autores (Bollag \& Barabasz, 1979; Beck 1981; Ross et al., 1981; Hattori, 1989; Schimming, 1992; Bardgett et al., 1994). Por outro lado, processos realizados por microrganismos específicos são mais sensiveis à presença de compostos tóxicos. Ueda et al. (1988a) afirmaram que o processo de amonificação da uréia não é tão afetado pela presença de metais pesados quanto o de nitrificação pois o primeiro é constituído de uma simples reação realizada por grande variedade de microrganismos, enquanto o processo de nitrificação envolve dois passos, é considerado mais complexo e envolve a participação de bactérias específicas.

$\mathrm{O}$ efeito de metais pesados sobre o processo de mineralização de compostos nitrogenados foi estudado por Beck (1981). Esse autor verificou que a taxa de nitrificação no solo é afetada em maior ou menor proporção quando da presença de 
$\mathrm{Cr}, \mathrm{Zn}$ e $\mathrm{Hg}$ enquanto que $\mathrm{Cd}, \mathrm{Cu}$ e $\mathrm{Ni}$ pouco efeito tiveram, mesmo em experimentos de longa duração. Este efeito foi maior em solos com reação ácida, quando comparados àqueles de reação alcalina, bem como foi menor em solos com maiores teores de argila.

Algumas espécies de microrganismos possuem capacidade de adaptação a altas concentrações de xenobióticos, mantendo os compostos tóxicos fora do interior das células. Outras utilizam mecanismos de redução do metal ou mesmo de formação de quelatos orgânicos (Kretzschmar, 1992; Schimming, 1992). Sabe-se também que a presença de matéria orgânica reduz o efeito tóxico de metais pesados sobre a atividade de microrganismos (Hattori, 1989).

Antes da aplicação de lodo deve ser considerada a contaminação do solo com metais, a presença de compostos halogênicos, o período de carência necessário, a categoria de uso do solo e a cultura agrícola, bem como a origem do lodo.

É sabido que a utilização de lodo de esgoto aumenta o teor de metais pesados em solos (Hattori, 1989; Alloway, 1990; Munier-Lamy et al., 1991; Hattori, 1992; Eivazi \& Zakaria, 1993). No entanto, pouco se conhece sobre as conseqüencias desta prática, nem mesmo o limite a partir do qual estes metais estariam afetando a atividade dos microrganismos.

A aplicação de lodo contribui com grande quantidade de matéria orgânica e de nutrientes, favorecendo as propriedades fisico-químicas e biológicas do solo. Pouco tempo após a aplicação do lodo ocorre aumento da biomassa microbiana e aumento na atividade enzimática.

Alguns autores não vêem inconvenientes na aplicação de lodo de esgoto no solo. Kretzschmar (1992) acredita que as vantagens da utilização de lodo como fertilizante superam as desvantagens, tais como a incorporação de metais pesados e compostos halogênicos orgânicos. Mesmo porquê, as ligações formadas entre estes metais e as substâncias húmicas, ou mesmo com minerais de argila, reduzem seus efeitos adversos. No entanto, deve ser tomada cautela quando a qualidade do lodo de esgoto não é bem conhecida, quando existe o risco de contaminação do lençol freático, quando se aplica resíduo em excesso e grande mobilidade de metais pesados, o que ocorre em solos arenosos e pobres em matéria orgânica. 
Quando se avalia a taxa de mineralização dos componentes orgânicos do lodo, deve-se levar em consideração a textura do solo, a quantidade de nutrientes disponíveis para plantas e a profundidade de aplicação. A aplicação de lodo em solos arenosos altera as propriedades físico-químicas, melhorando a retenção de água e de nutrientes. Por possuírem boa aeração, os solos arenosos são conhecidos por rápida mineralização de substâncias orgânicas, baixa capacidade de adsorção, resultando em perdas por lixiviação e mesmo excesso de nutrientes para as plantas, quando da aplicação de altas doses de lodo. Juntamente com o lodo são adicionados organismos com sistemas enzimáticos específicos, capazes de degradar substâncias orgânicas tóxicas decomponiveis, aumentando a capacidade do solo em degradar e mineralizar resíduos eventualmente tóxicos (Kretzschmar, 1992).

Por outro lado, Chander et al. (1995) observaram que o lodo de esgoto aumenta a biomassa microbiana em torno de $30 \%$ quando aplicado na dose de $40 \mathrm{t} \mathrm{ha}^{-1}$, e de 4 a 5 vezes quando na dose de $160 \mathrm{t} \mathrm{ha}^{-1}$ após quatro semanas de incubação, independentemente do teor de metais deste lodo. No entanto, após 64 semanas foi verificado que os tratamentos que receberam doses mais elevadas de metais pesados apresentaram uma biomassa menor do que aqueles que receberam lodo com baixos teores de metais ou mesmo os tratamentos que não receberam lodo. Segundo estes autores, a quantidade de nitrogênio inorgânico no tratamento controle aumentou com o decorrer do período de incubação. No entanto, o nitrogênio inorgânico em todos os solos que receberam lodo caiu praticamente a zero após quatro semanas de incubação, provavelmente devido aos processos de imobilização ou de desnitrificação. Estes autores também encontraram uma correlação positiva entre o carbono proveniente da biomassa e a atividade da desidrogenase em todos os solos que receberam lodo, embora a atividade da desidrogenase tenha sido de aproximadamente um quarto nos tratamentos que receberam lodo rico em cobre.

Suttonn et al. (1991), trabalhando com fertilizantes e lodo de esgoto em um experimento de 11 anos, constataram que as parcelas que receberam tanto adubação orgânica como mineral apresentaram baixa atividade microbiológica, avaliada através da atividade da desidrogenase, quando comparadas com o controle. As parcelas que 
receberam calcário, além dos fertilizantes, apresentaram maior atividade metabólica de microrganismos do que as que não receberam. Segundo estes autores, a elevação do $\mathrm{pH}$ pela calagem restaurou a atividade microbiológica do solo que recebeu lodo e fertilizante para níveis próximos aos do controle, em apenas uma estação de crescimento.

Eivazi \& Zakaria (1993) verificaram a ação do lodo de esgoto sobre a atividade da glucosidase em laboratório. Em doses elevadas de lodo, observaram efeito inibitório, mas com manutenção da atividade enzimática. Segundo estes autores, a presença de matéria orgânica e minerais de argila diminui o efeito adverso de metais pesados sobre a atividade microbiana.

Leita et al. (1995), verificando a biodisponibilidade de $\mathrm{Pb}, \mathrm{Zn}$ e Ti para microrganismos, notaram um aumento significativo da liberação de $\mathrm{CO}_{2}$ nos solos contaminados. Esses autores creditam este fato à necessidade de os microrganismos dispenderem mais energia para sobreviver quando submetidos a condições de estresse. Diferentemente desses autores, Hattori (1992) observou um decréscimo na liberação de $\mathrm{CO}_{2}$ quando $\mathrm{Cd}, \mathrm{Cr}, \mathrm{Cu}, \mathrm{Ni}, \mathrm{Pb}$ e $\mathrm{Zn}$ estavam presentes no solo. Observou, também, um comportamento diferenciado entre os diferentes metais e os dois solos com os quais trabalhou (Gley e Andosol). Chang \& Broadbent (1981) também observaram um decréscimo na taxa respiratória de microrganismos submetidos a estresse proporcionado por metais pesados.

A respiração microbiana no solo pode ser definida como o consumo de oxigênio ou liberação de gás carbônico através da atividade da microbiota e da mesofauna, compreendendo todas as trocas gasosas dos metabolismos aeróbio e anaeróbio resultantes da degradação de substâncias orgânicas através de diversos processos metabólicos, onde a produção de gás carbônico é o estádio final da mineralização dos compostos de carbono.

Respiração basal é definida como a respiração realizada pelos microrganismos do solo quando este não é alterado pela adição de qualquer material (adição de nutrientes por exemplo) e apresenta um equilíbrio entre o número de microrganismos e sua atividade. Quando este equilíbrio é alterado, como quando da adição de matéria orgânica, observa-se a alteração na taxa de respiração microbiana, 
devido ao intenso crescimento de microrganismos e conseqüente aumento na taxa de mineralização. Desta forma, a liberação de $\mathrm{CO}_{2}$ é uma maneira de se avaliar a atividade dos microrganismos do solo.

A avaliação da liberação de $\mathrm{CO}_{2}$, além de quantificar a atividade respiratória de microrganismos no substrato original, pode também avaliar a influência de fatores ambientais sobre a atividade respiratória ou mesmo a velocidade de degradação de um determinado substrato.

Na determinação do $\mathrm{CO}_{2}$ por titulometria, o substrato é incubado em frasco fechado, à temperatura constante, e o gás carbônico produzido é absorvido por solução de hidróxido de sódio. Alíquotas de amostras de solo são acondicionados em frasco de vidro de $1,5 \mathrm{~L}$, fechados hermeticamente, contendo cadinho com $15 \mathrm{~mL}$ de solução de $\mathrm{NaOH} 0,05 \mathrm{~N}$ e são incubadas em sala climatizada com temperatura constante.

Após 24 horas de incubação, os cadinhos com solução de $\mathrm{NaOH}$ são retirados e recebem solução de cloreto de bário $\left(\mathrm{BaCl}_{2}\right)$, para precipitar o carbonato na forma de $\mathrm{BaCO}_{3}$ (sal estável) e impedir que o $\mathrm{Na}_{2} \mathrm{CO}_{3}$ ou $\mathrm{NaHCO}_{2}$ formado seja desdobrado em $\mathrm{NaOH}+\mathrm{CO}_{2}$ novamente, quando da titulação com $\mathrm{HCl}$. A soda que não reagiu com o $\mathrm{CO}_{2}$ é titulada com $\mathrm{HCl} 0,5 \mathrm{~N}$ na presença do indicador fenoftaleina (Schinner et al., 1993)

$\mathrm{O} \mathrm{CO}_{2}$ produzido pode ser quantificado por titulometria, como descrito acima, ou por Injeção em Fluxo Contínuo (Flow Injection Analysis)-FIA, como descrito por Jardim et al. (1990) e por Andrade et al. (1994).

Freqüentemente a determinação de $\mathrm{CO}_{2}$ é feita por titulometria devido à maior simplicidade e menor custo. $\mathrm{O}$ uso do sistema FIA permite, no entanto, a determinação de concentrações de $\mathrm{CO}_{2}$ bem menores e em pequenos intervalos de tempo, sendo, portanto, uma técnica mais sensível do que a determinação por titulometria.

Segundo Reis (1996), a análise química por injeção em fluxo é a versão mais usual em português do título em inglês "Flow Injection Analysis", de onde foi derivada a sigla FIA, internacionalmente conhecida. Ainda, segundo este autor, o 
processo de análise química por injeção em fluxo tem como conceito clássico a inserção da amostra em um fluido carregador que a transporta para o detector.

Ueda et al. (1988b) pesquisaram a ação do $\mathrm{Na}_{2} \mathrm{CrO}_{4}$ combinado com palha de arroz e esterco de gado sobre a atividade e composição de microrganismos do solo e perceberam que a adição de $100 \mathrm{mg} \mathrm{kg}^{-1} \mathrm{de} \mathrm{Cr}$ aumentou a comunidade de fungos. Admitem, no entanto, que o número de espécies de fungos sensíveis a $\mathrm{Cr}$ diminuiu. Segundo esses autores, o número de bactérias nos tratamentos com $\mathrm{Cr}$ permaneceu com a mesma ordem de grandeza do controle. A liberação de $\mathrm{CO}_{2}$ foi reduzida quando da adição de $20 \mathrm{mg} \mathrm{kg}^{-1}$ de $\mathrm{Cr}$ e fortemente inibida com a dose de $100 \mathrm{mg} \mathrm{kg}^{-1}$. A palha de arroz e o esterco de gado promoveram a redução do $\mathrm{Cr}$ da forma hexavalente para a forma trivalente. Quando a palha e o esterco foram colocados juntos, o processo foi mais rápido, mostrando o estímulo à atividade microbiana.

A capacidade de acumulação de metais em solos argilosos é maior, reduzindo a contaminação de águas subterrâneas, diferentemente do que ocorre em solos arenosos que possuem baixa capacidade de retenção, ou seja, os solos arenosos não devem receber altas doses de lodo de esgoto quando se pretende evitar que a água subterrânea e as culturas sejam contaminadas. 


\section{MATERIAL E MÉTODOS}

\subsection{Contagem de microrganismos do solo pelo método de plaqueamento de gotas}

No desenvolvimento de um método simplificado para determinação do número mais provável (NMP) de microrganismos do solo, foram utilizados os meios de cultura ágar nutriente (Burnett et al., 1957) para determinação de bactérias e o meio de Martin, com exclusão do rosa bengala, para determinação de fungos (Martin, 1950). A composição dos meios utilizados é a seguinte: Ágar Nutriente (1000 mL água, $10 \mathrm{~g}$ ágar, $3 \mathrm{~g}$ extrato de carne, $10 \mathrm{~g} \mathrm{NaCl}, 5 \mathrm{~g}$ peptona); Meio de Martin (1000 $\mathrm{mL}$ água, $10 \mathrm{~g}$ ágar, $1 \mathrm{~g} \mathrm{KH}_{2} \mathrm{PO}_{4}, 1 \mathrm{~g} \mathrm{MgSO}_{4} .7 \mathrm{H}_{2} \mathrm{O}, 5 \mathrm{~g}$ peptona, $10 \mathrm{~g}$ dextrose, $0,03 \mathrm{~g}$ estreptomicina).

Os tubos de ensaio, após receberam o meio de cultura correspondente foram autoclavados por 20 minutos a $120^{\circ} \mathrm{C}$ e 1 atm. e posteriormente mantidos em banho maria a $45^{\circ} \mathrm{C}$ para que o meio de cultura permanecesse em estado líquido. Para a realização da série de diluições, foi obtida uma suspensão, em frasco Erlenmeyer, utilizando-se $10 \mathrm{~g}$ de terra e $90 \mathrm{~mL}$ de solução salina de $\mathrm{NaCl}$ a $0,85 \%$. A partir desta suspensão, foram realizadas diluições sucessivas com alíquotas de $0,1 \mathrm{~mL}$ nos tubos de ensaio contendo $0,9 \mathrm{~mL}$ de meio de cultura agarizado a $1 \%$ e tampados com algodão e mantidos em banho maria até o momento do plaqueamento.

O plaqueamento do meio de cultura agarizado foi realizado em câmara de fluxo laminar, em placas de Petri esterilizadas, com gotas de $0,04 \mathrm{~mL}$ com auxílio de micropipeta. As placas foram vedadas com parafilm® para impedir perda de água e incubadas em estufa para D.B.O. (demanda bioquímica de oxigênio) mantida a $28^{\circ} \mathrm{C}$ por um período de 48 horas. Após o período de incubação, foi verificado, com o auxílio de uma lupa, o número de gotas positivas, ou seja, aquelas onde ocorreu o crescimento de 
pelo menos um microrganismos do grupo de interesse. $\mathrm{O}$ crescimento em uma gota mostra que pelo menos um propágulo, capaz de se desenvolver, foi transferido para o meio de cultura. A partir dos resultados obtidos em cada uma das diluições, pode-se estimar o número mais provável (NMP) de microrganismos com o auxílio de uma tabela de probabilidade de ocorrência (tabela de McCrady). A figura 1 mostra uma placa de Petri após o plaqueamento do meio de cultura agarizado.

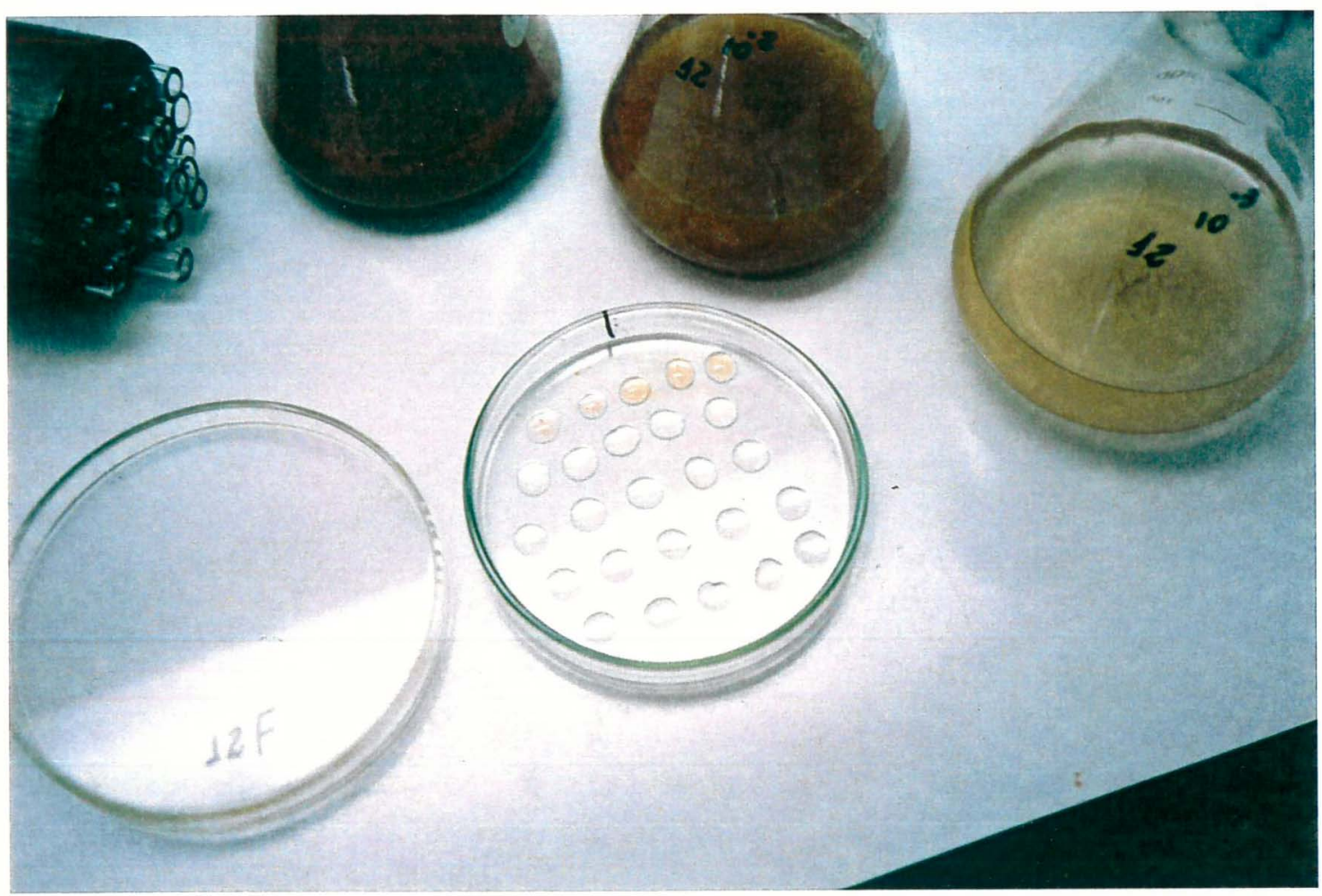

Figura 1. Diluição da amostra em solução salina e placa de Petri com gotas. 
Para verificar a viabilidade do método de plaqueamento de gotas, foram realizados 4 experimentos:

I. Comparação entre a metodologia tradicional e a metodologia proposta.

II. Avaliação das metodologias de quantificação de microrganismos em amostras de solo de diferentes texturas.

III. Avaliação do efeito de agentes desagregantes.

IV. Verificação da sensibilidade da metodologia proposta a diferentes fontes de matéria orgânica e à presença de crômio na forma de sal.

3.1.1 Experimento I: Comparação entre a metodologia tradicional e a metodologia proposta.

Para o primeiro experimento foi utilizada uma amostra de terra, seca ao ar e peneirada em tamis com $2 \mathrm{~mm}$ de malha. As características químicas da amostra se encontram no quadro 1.

Para cada metodologia de quantificação de microrganismos foram realizadas 6 repetições e foram quantificados o NMP de bactérias e o NMP de fungos. As diluições foram feitas utilizando-se suspensão de $10 \mathrm{~g}$ de terra em $90 \mathrm{~mL}$ de solução salina de $\mathrm{NaCl}$ a $0,85 \%$. Os frascos Erlenmeyer contendo as suspensões foram agitados por 10 minutos em agitador com movimento circular-horizontal. A partir deste frasco foram preparadas diluições para o procedimento convencional e para o plaqueamento de gotas.

No procedimento tradicional de contagem de microrganismos, diluições sucessivas foram feitas em frascos Erlenmeyer até a diluição $10^{-3}$, utilizando-se alíquotas de $10 \mathrm{~mL}$ da diluição anterior. A partir desta diluição, alíquotas de $1 \mathrm{~mL}$ foram transferidas para tubo de ensaio contendo $9 \mathrm{~mL}$ de solução salina até se atingir a diluição $10^{-8}$ para bactérias e $10^{-6}$ para fungos. Os meios de cultura utilizados são os mesmos que foram utilizados para o método de plaquemento de gotas. 
Todas as amostras foram mantidas em estufa incubadora para D.B.O. com temperatura constante de $28^{\circ} \mathrm{C}$ por um período de 48 horas no método de plaqueamento de gotas, e por 72 horas para bactérias e 120 horas para fungos no método tradicional. Após os respectivos períodos de incubação, foi feita a contagem de tubos com ou sem crescimento, para que fosse calculado o NMP através de tabela de probabilidade. Os procedimentos para a quantificação através da metodologia de plaqueamento de gotas estão descritos no item 3.1.

Quadro 1. Características químicas da amostra de solo utilizado no experimento I.

\begin{tabular}{|lc|}
\hline \multicolumn{1}{|c|}{ Parâmetros Avaliados } & Valor \\
\hline $\mathrm{pH}\left(\mathrm{CaCl}_{2}\right)$ & 5,5 \\
M.O. $\left(\mathrm{g} \mathrm{dm}^{-3}\right)$ & 33 \\
P resina $\left(\mathrm{mg} \mathrm{dm}{ }^{-3}\right)$ & 44 \\
$\mathrm{~K}^{+}\left(\mathrm{mmol}_{\mathrm{c}} \mathrm{dm}^{-3}\right)$ & 7,5 \\
$\mathrm{Ca}^{2+}\left(\mathrm{mmol}_{\mathrm{c}} \mathrm{dm}^{-3}\right)$ & 73,0 \\
$\mathrm{Mg}^{2+}\left(\mathrm{mmol}_{\mathrm{c}} \mathrm{dm}^{-3}\right)$ & 21,0 \\
$\mathrm{H}^{+}+\mathrm{Al}^{3+}\left(\mathrm{mmol}_{\mathrm{c}} \mathrm{dm}^{-3}\right)$ & 20,0 \\
$\mathrm{~S}\left(\mathrm{mmol}_{\mathrm{c}} \mathrm{dm}^{-3}\right)$ & 101,5 \\
$\mathrm{~T}\left(\mathrm{mmol}_{\mathrm{c}} \mathrm{dm}^{-3}\right)$ & 121,5 \\
$\mathrm{~V} \%$ & 84 \\
\hline
\end{tabular}

3.1.2 Experimento II: Avaliação das metodologias de quantificação de microrganismos em amostras de solo de diferentes texturas.

Para o segundo experimento foram utilizadas amostras secas ao ar de três solos de texturas distintas que se encontravam armazenados por longo período, cujas características estão listadas no quadro 2.

Foram realizadas 5 repetições para cada amostra de solo e as variáveis observadas foram NMP de bactérias e de fungos. Os procedimentos neste experimento 
são os mesmos indicados para a metodologia de plaqueamento de gotas e tradicional já descritas.

3.1.3 Experimento III: Avaliação do efeito de agentes desagregantes.

Uma amostra de solo argiloso de $300 \mathrm{~g}$, cujas características químicas se encontram no quadro 2 , foi cuidadosamente misturada com uma dose correspondente a aplicação de $50 \mathrm{t} \mathrm{ha}^{-1}$ de lodo de curtume seco e peneirado. A mistura umedecida, foi acondicionada em copo plástico que permaneceu por um período de 25 dias em sala climatizada a $28^{\circ} \mathrm{C}$.

Os tratamentos foram:

1. testemunha

2. $5 \mathrm{~g}$ de areia lavada

3. 1 esfera de vidro de $3 \mathrm{~mL}$ de volume

4. 10 pérolas de vidro

Todos os desagregantes utilizados foram lavados em água destilada e autoclavados misturados com $90 \mathrm{~mL}$ da solução salina em frascos Erlenmeyer.

Para a obtenção da suspensão, forma adicionados $10 \mathrm{~g}$ de terra nos frascos Erlenmeyer que foram então agitados por um período de 10 minutos em agitador com movimento circular-horizontal. A partir deste frasco foram preparadas diluições para o procedimento convencional e para o plaqueamento de gotas. 
Quadro 2. Características químicas das amostras de solos utilizadas no experimento II.

\begin{tabular}{|lccc|}
\hline Parâmetros Avaliados & Solo l & Solo 2 & Solo 3 \\
\hline $\mathrm{pH}\left(\mathrm{CaCl}_{2}\right)$ & 7,6 & 4,3 & 5,2 \\
$\mathrm{M} . \mathrm{O} .\left(\mathrm{g} \mathrm{dm}^{-3}\right)$ & 150,0 & 8 & 18 \\
$\mathrm{P} \mathrm{resina}\left(\mathrm{mg} \mathrm{dm}^{-3}\right)$ & 36 & 28 & 23 \\
$\mathrm{~K}^{+}\left(\mathrm{mmol}_{\mathrm{c}} \mathrm{dm}^{-3}\right)$ & 6,8 & 2,7 & 1,4 \\
$\mathrm{Ca}^{2+}\left(\mathrm{mmol}_{\mathrm{c}} \mathrm{dm}^{-3}\right)$ & 470 & 21 & 25 \\
$\mathrm{Mg}^{2+}\left(\mathrm{mmol}_{\mathrm{c}} \mathrm{dm}^{-3}\right)$ & 270 & 4 & 5 \\
$\mathrm{Al}^{3+}\left(\mathrm{mmol}_{\mathrm{c}} \mathrm{dm}^{-3}\right)$ & 0 & 10 & 0 \\
$\mathrm{H}^{+}+\mathrm{Al}^{3+}\left(\mathrm{mmol}_{\mathrm{c}} \mathrm{dm}^{-3}\right)$ & 1 & 58 & 32 \\
$\mathrm{~S}\left(\mathrm{mmol}_{\mathrm{c}} \mathrm{dm}^{-3}\right)$ & 746,8 & 27,7 & 31,4 \\
$\mathrm{~T}\left(\mathrm{mmol}_{\mathrm{c}} \mathrm{dm}^{-3}\right)$ & 747,8 & 85,7 & 63,4 \\
$\mathrm{~V} \%$ & 100 & 32,3 & 50 \\
saturação com Al & $\%$ & 27 & 0 \\
areia fina \% & 0 & 74 & 82 \\
silte \% & 24 & 8 & 4 \\
argila \% & 24 & 18 & 14 \\
\hline
\end{tabular}

3.1.4 Experimento IV: Verificação da sensibilidade da metodologia proposta a diferentes fontes de matéria orgânica e à presença de crômio na forma de sal.

Foram utilizados bagaço de cana seco e moído e composto orgânico preparado a partir de restos vegetais proveniente do parque da ESALQ obtido após período de compostagem de 60 dias.

Utilizou-se amostra de solo argiloso seco ao ar e peneirado em tamis de $2 \mathrm{~mm}$. As características do solo e da matéria orgânica utilizada estão listadas no quadro 3. As análises foram realizadas nos laboratórios do Departamento de Ciência do Solo da ESALQ-USP. 
O experimento foi instalado em um fatorial com 6 diferentes combinações de resíduo orgânico e terra, quatro datas de coletas e três repetições em delineamento completamente aleatorizado totalizando 72 parcelas. As terras foram mantidas em copos plásticos perfurados com capacidade de $300 \mathrm{~mL}$ com umidade próxima à capacidade de retenção de água em sala climatizada, com temperatura constante de $28^{\circ} \mathrm{C}$ por um período de 28 dias.

Para o preparo da solução de $\mathrm{Cr}$ foi utilizado dicromato de potássio $\left(\mathrm{K}_{2} \mathrm{Cr}_{2} \mathrm{O}_{7}\right)$ dissolvido em água destilada e essa solução foi aplicada na terra durante a

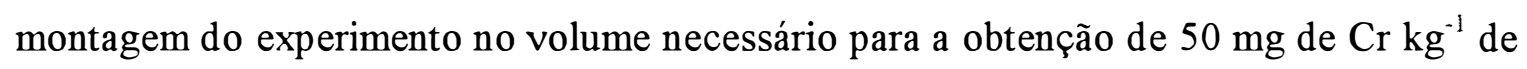
solo.

Os tratamentos foram os seguintes:

\section{Terra}

2. Terra + Bagaço de Cana $\left(10 \mathrm{~g} \mathrm{~kg}^{-1}\right.$ de solo)

3. Terra + Composto $\left(30 \mathrm{~g} \mathrm{~kg}^{-1}\right.$ de solo)

4. Terra + Solução de $\operatorname{Cr}\left(50 \mathrm{mg} \mathrm{kg}^{-1}\right.$ solo $)$

5. Terra + Bagaço de Cana (10 $\mathrm{g} \mathrm{kg}^{-1}$ de solo $)+$ Solução de $\operatorname{Cr}\left(50 \mathrm{mg} \mathrm{kg}^{-1}\right)$

6. Terra + Bagaço de Cana ( $10 \mathrm{~g} \mathrm{~kg}^{-1}$ de solo $)+$ Composto $\left(30 \mathrm{~g} \mathrm{~kg}^{-1}\right.$ de solo $)+$ Solução de $\operatorname{Cr}\left(50 \mathrm{mg} \mathrm{kg}^{-1}\right)$.

Os diferentes materiais foram cuidadosamente misturados e acondicionados aos copos plásticos, recebendo água destilada com regularidade. Semanalmente foram avaliadas a produção de $\mathrm{CO}_{2}$ pelo método de Öhlinger (1993) e o número mais provável de fungos e bactérias de acordo com os procedimentos descritos no item 3.1.

Em intervalos de 7 dias, os conteúdos dos copos a serem avaliados eram homogeneizados e uma alíquota de $10 \mathrm{~g}$ era utilizada para a determinação do número mais provável de fungos e bactérias, outra de $50 \mathrm{~g}$ para a determinação de produção de $\mathrm{CO}_{2}$ e mais uma de $10 \mathrm{~g}$ para determinação da umidade. 
Quadro 3. Características químicas da amostra de solo e dos resíduos orgânicos utilizados no experimento III.

\begin{tabular}{|c|c|c|c|}
\hline Parâmetros Avaliados & Solo & Composto & Bagaço de Cana \\
\hline $\mathrm{pH}\left(\mathrm{CaCl}_{2}\right)$ & 5,5 & 6,8 & 4,9 \\
\hline M.O. $\left(\mathrm{g} \mathrm{dm}^{-3}\right)$ & 33 & 274,6 & 955,8 \\
\hline $\mathrm{P} \mathrm{g} \mathrm{kg}^{-1}$ & $44\left(\mathrm{mg} \mathrm{dm}^{-3}\right)$ & 2,23 & 0,0874 \\
\hline $\mathrm{K}^{+} \mathrm{g} \mathrm{kg}^{-1}$ & $7,5\left(\mathrm{mmol}_{\mathrm{c}} \mathrm{dm}^{-3}\right)$ & 2,9 & 1,1 \\
\hline $\mathrm{Ca}^{2+} \mathrm{g} \mathrm{kg}^{-1}$ & $73\left(\mathrm{mmol}_{\mathrm{c}} \mathrm{dm}^{-3}\right)$ & 12,8 & 0,2 \\
\hline $\mathrm{Mg}^{2+} \mathrm{g} \mathrm{kg}^{-1}$ & $21\left(\mathrm{mmol}_{\mathrm{c}} \mathrm{dm}^{-3}\right)$ & 2,1 & 0,4 \\
\hline $\mathrm{N}$ total $\mathrm{g} \mathrm{kg}^{-1}$ & & 19,2 & 2,9 \\
\hline $\mathrm{H}^{+}+\mathrm{Al}^{3+}$ & $20\left(\mathrm{mmol}_{\mathrm{c}} \mathrm{dm}^{-3}\right)$ & & \\
\hline$S$ & $102\left(\mathrm{mmol}_{\mathrm{c}} \mathrm{dm}^{-3}\right)$ & & \\
\hline $\mathrm{T}$ & $122\left(\mathrm{mmol}_{\mathrm{c}} \mathrm{dm}^{-3}\right)$ & & \\
\hline $\mathrm{V} \%$ & 84 & & \\
\hline Umidade $\mathrm{g} \mathrm{kg}^{-1}$ & & 474,6 & 56,0 \\
\hline Cinzas $\mathrm{g} \mathrm{kg}^{-1}$ (base seca) & & 725,4 & 44,2 \\
\hline Relação C/N & & $8 / 1$ & $185 / 1$ \\
\hline
\end{tabular}

\subsection{Método FIA de avaliação da produção de $\mathrm{CO}_{2}$}

$\mathrm{Na}$ análise por injeção em fluxo contínuo, a amostra em solução aquosa é introduzida em um fluido carregador, que a transporta em direção ao detetor (Figura 2). Durante o transporte a amostra se dispersa continuamente no fluido carregador, gerando um gradiente de concentração no percurso analítico. $O$ volume da amostra empregado em cada determinação é definido pelo comprimento da alça de amostragem. Aumentando-se o comprimento da alça de amostragem, aumenta-se o sinal gerado pelo detector (Reis et al., 1989).

Para a determinação de $\mathrm{CO}_{2}$ pela técnica do FIA foram utilizados os procedimentos descritos por Miyazawa, et al. (1996). Segundo estes autores, o método se baseia na injeção de volume selecionado da amostra no sistema que, após confluência com solução de $\mathrm{H}_{2} \mathrm{SO}_{4}$, desprende $\mathrm{CO}_{2}$. $\mathrm{O}$ gás desprendido é separado através de membrana semipermeável (Teflon $®)$ dissolvendo-se em água destilada e desgaseificada, formando $\mathrm{H}_{2} \mathrm{CO}_{3}$. A concentração de $\mathrm{CO}_{2}$ é determinada pela condutividade elétrica da solução. 
Para a condução da água destilada e desgaseificada foi utilizado tubo de Tygon $^{\circledR}$ azul-amarelo que possui diâmetro interno de $1,52 \mathrm{~mm}$; para os demais reagentes foram utilizados tubos verde-verde, que possuem 1,85 mm de diâmetro interno.

A bomba peristáltica utilizada foi ISMATEC ${ }^{\circledR}$ IPC- 8 , trabalhando a $20 \%$ da taxa de fluxo, o que corresponde a um fluxo de $2,8 \mathrm{~mL} / \mathrm{min}$ para o tubo de 1,52 $\mathrm{mm}$ e de $4,2 \mathrm{~mL} / \mathrm{min}$ para o tubo de $1,85 \mathrm{~mm}$. Estes valores são fornecidos pelo fabricante da bomba peristáltica e não são exatos, pois dependem da idade do tubo utilizado, das condições de pressão, dos ajustes dos tubos e da viscosidade dos líquidos utilizados.

A calibração das soluções padrão de carbonato de sódio $\left(\mathrm{Na}_{2} \mathrm{CO}_{3}\right)$ foram feitas com os valores de $0,20,40,80,100$ e $140 \mathrm{mmol} \mathrm{L}^{-1}$. A partir dos picos obtidos no registrador potenciométrico foram determinadas as equações de regressão.

Os dados de produção de $\mathrm{CO}_{2}$ obtidos graficamente foram medidos e submetidos a programa de regressão desenvolvido no CENA para a obtenção da quantidade de $\mathrm{CO}_{2} \mathrm{em} \mathrm{mg} \mathrm{g}^{-1}$ de terra. 


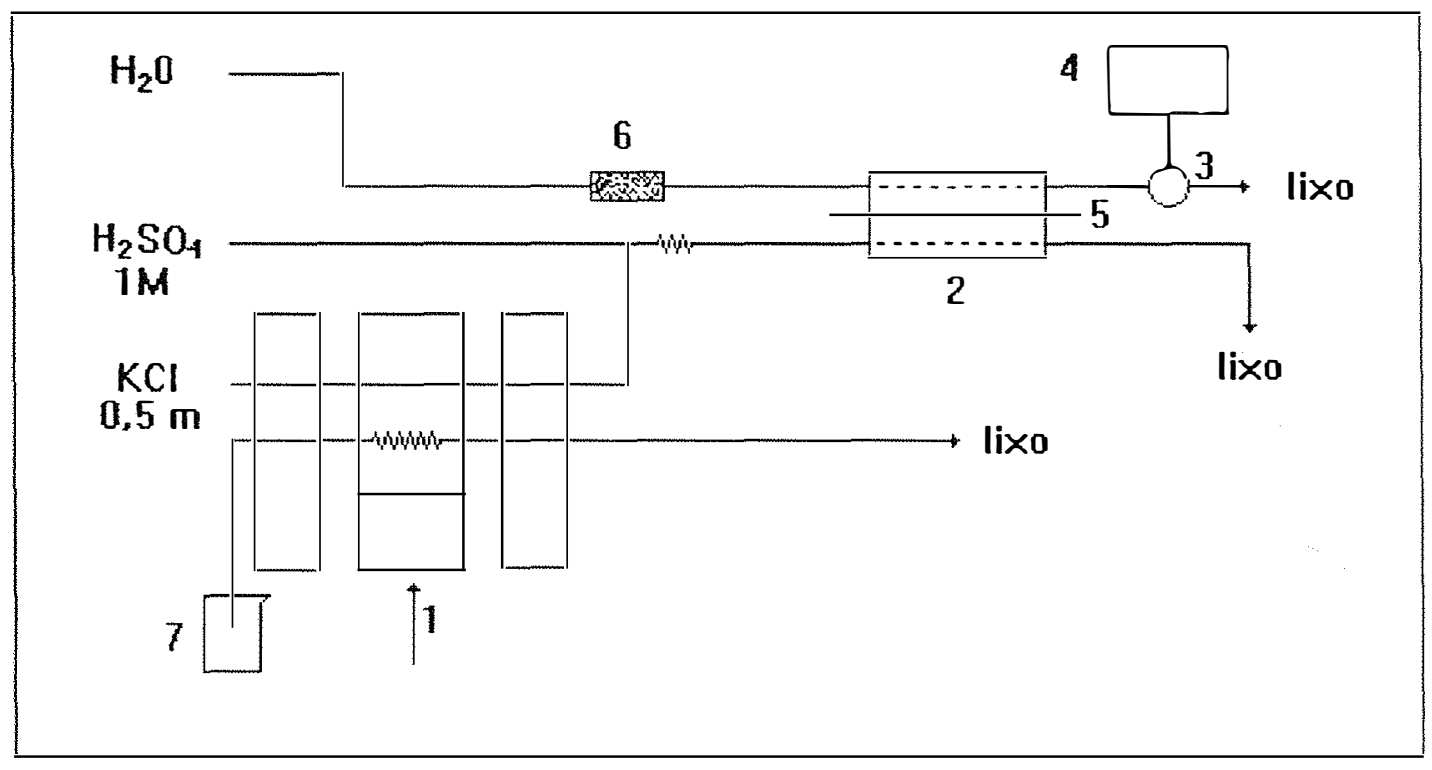

1. Injetor de amostra

3. Célula condutivimétrica

5. Membrana semipermeável $\left(\right.$ Teflon $\left.^{\text {ख) }}\right)$

7. Amostra
2. Câmara de difusão de gás

4. Condutivímetro

6. Resina troca iônica.

Figura 2. Determinação do $\mathrm{CO}_{2}$ em amostra de $\mathrm{NaOH}$ por condutivimetria em sistema de injeção em fluxo - FIA. Fonte: Miyazawa et al. (1996). 


\subsection{Avaliação da degradação de lodo de curtume}

Após a definição das metodologias de contagem de bactérias e fungos, bem como da quantificação de $\mathrm{CO}_{2}$, foi montado experimento para avaliar a degradação de lodo de esgoto proveniente de indústria de processamento de couro no solo.

$\mathrm{O}$ experimento foi instalado em um fatorial com 4 doses de lodo de esgoto $\left(0,11,9,23,8,47,6 \mathrm{~g} \mathrm{~kg}^{-1}\right.$ de solo), 2 tipos de terra (arenosa e argilosa) e 7 épocas de coleta $(1,11,21,31,41,51,61$ dias de incubação), com 3 repetições, perfazendo um total de 168 parcelas.

As doses de lodo de esgoto utilizadas neste trabalho foram calculadas em função da quantidade de matéria orgânica a ser aplicada por hectare equivalendo a 0 , 10,25 e $50 \mathrm{t} \mathrm{ha}^{-1}$. Os valores de $\mathrm{Cr}$ aplicados excedem os valores máximos determinados pelo ministério da saúde da República Federal da Alemanha, que determina um valor máximo para solo de $100 \mathrm{mg}$ de crômio por quilograma de terra. Assim, tem-se doses de até 10 vezes o valor limite recomendado.

Cada parcela foi constituída de copo plástico com capacidade de 500 $\mathrm{mL}$ de volume, com $27 \mathrm{~cm}$ de altura e $9 \mathrm{~cm}$ de diâmetro na parte superior e com furos na parte inferior permitindo a drenagem. Cada copo recebeu $300 \mathrm{~g}$ de terra mais a respectiva quantidade de lodo seco e moído.

Completada a mistura da terra com o lodo seco, foram adicionados 40 $\mathrm{mL}$ de água destilada e os copos foram mantidos em sala climatizada com temperatura constante de $28^{\circ} \mathrm{C}$. Após 24 horas, realizou-se a primeira coleta para as análises propostas. As demais coletas foram realizadas com intervalos de 10 dias.

As características químicas e granulométricas das terras, , bem como a composição do lodo de esgoto utilizado, estão nos quadros 4,5 e 6 , respectivamente. $O$ lodo é proveniente da estação de tratamento de esgoto do curtume Pó de Boi, localizado no município de Leme/SP, e constitui-se de mistura de lodo de esgoto e lodo ativado. $\mathrm{O}$ lodo foi coletado no curtume em tambor plástico, sendo acondicionado em câmara fria $\left(4^{\circ} \mathrm{C}\right)$. Posteriormente, o lodo foi seco em estufa a $60^{\circ} \mathrm{C}$ e moído em moinho equipado com tamis de $2,0 \mathrm{~mm}$ e mantido em câmara fria $\left(4^{\circ} \mathrm{C}\right)$ para posterior utilização. 
Quadro 4. Características químicas das terras utilizadas na avaliação da degradação de lodo .

\begin{tabular}{|c|c|c|}
\hline Parâmetros avaliados & Arenoso & Argiloso \\
\hline $\mathrm{pH}\left(\mathrm{CaCl}_{2}\right)$ & 4,0 & 4,3 \\
\hline matéria orgânica $\left(\mathrm{g} \mathrm{dm}^{-3}\right)$ & 14 & 28 \\
\hline P resina $\left(\mathrm{mmol}_{\mathrm{c}} \mathrm{dm}^{-3}\right)$ & 60 & 530 \\
\hline $\mathrm{K}^{+}\left(\mathrm{mmol}_{\mathrm{c}} \mathrm{dm}^{-3}\right)$ & 0,7 & 4,5 \\
\hline $\mathrm{Ca}^{+2}\left(\mathrm{mmol}_{\mathrm{c}} \mathrm{dm}^{-3}\right)$ & 1 & 16 \\
\hline $\mathrm{Mg}^{2+}\left(\mathrm{mmol}_{\mathrm{c}} \mathrm{dm}^{-3}\right)$ & 2 & 10 \\
\hline $\mathrm{H}+\mathrm{Al}^{+3}\left(\mathrm{mmol}_{\mathrm{c}} \mathrm{dm}^{-3}\right)$ & 34 & 72 \\
\hline $\mathrm{S}\left(\mathrm{mmol}_{\mathrm{c}} \mathrm{dm}^{-3}\right)$ & 4 & 31 \\
\hline $\mathrm{T}\left(\mathrm{mmol}_{\mathrm{c}} \mathrm{dm}^{-3}\right)$ & 38 & 103 \\
\hline V (\%) & 11 & 30 \\
\hline
\end{tabular}

Quadro 5. Composição granulométrica das terras utilizadas na avaliação da degradação de lodo .

\begin{tabular}{|lcc|}
\hline Classes de diâmetro & Terra arenosa & Terra argilosa \\
\hline Areia muito grossa $(1-2 \mathrm{~mm})$ & 1 & - \\
Areia grossa $(0,5-1 \mathrm{~mm})$ & 8 & 1 \\
Areia média $(0,25-0,5 \mathrm{~mm})$ & 24 & 4 \\
Areia fina $(0,1-0,25 \mathrm{~mm})$ & 45 & 11 \\
Areia muito fina $(0,05-0,1 \mathrm{~mm})$ & 4 & 3 \\
Areia total $(0,05-2 \mathrm{~mm})$ & 82 & 19 \\
Silte $(0,002-0,05 \mathrm{~mm})$ & 2 & 12 \\
Argila em água $(<0,002 \mathrm{~mm})$ & 6 & 37 \\
Argila total $(<0,002 \mathrm{~mm})$ & 16 & 69 \\
\hline
\end{tabular}


Para a determinação dos metais do lodo foi realizada a digestão nitroperclórica, utilizando $1 \mathrm{~g}$ de lodo seco em estufa e passando $100 \%$ em peneira de 2 $\mathrm{mm}$ com $10 \mathrm{~mL}$ de $\mathrm{HNO}_{3}$ seguida de ácido perclórico $70 \%$ até $210^{\circ} \mathrm{C}$. O extrato resultante foi diluído em $50 \mathrm{~mL}$ de água destilada e o teor de $\mathrm{Cr}$ lido em espectrofotômetro de absorção atômica (AAS). As características do lodo seco e moido estão listadas no quadro 6.

Quadro 6. Composição do lodo de curtume, base produto seco.

\begin{tabular}{|ll|}
\hline Parâmetro Avaliado & Valor \\
\hline $\mathrm{pH}\left(\mathrm{CaCl}_{2}\right)$ & 7,3 \\
Matéria orgânica total $\left(\mathrm{g} \mathrm{dm}^{-3}\right)$ & 721,1 \\
Matéria orgânica compostável $\left(\mathrm{g} \mathrm{dm}^{-3}\right)$ & 718,0 \\
Resíduo mineral total $\left(\mathrm{g} \mathrm{dm}^{-3}\right)$ & 278,9 \\
Resíduo mineral solúvel $\left(\mathrm{g} \mathrm{dm}^{-3}\right)$ & 253,3 \\
$\mathrm{~N}$ total $\left(\mathrm{g} \mathrm{dm}^{-3}\right)$ & 39,6 \\
$\mathrm{P} \mathrm{resina}\left(\mathrm{mg} \mathrm{dm}^{-3}\right)$ & 1,57 \\
$\mathrm{~K}\left(\mathrm{mmol}_{\mathrm{c}} \mathrm{dm}^{-3}\right)$ & 0,75 \\
$\mathrm{Ca}\left(\mathrm{mmol}_{\mathrm{c}} \mathrm{dm}^{-3}\right)$ & 80.2 \\
$\mathrm{Mg}\left(\mathrm{mmol}_{\mathrm{c}} \mathrm{dm}^{-3}\right)$ & 1,9 \\
$\mathrm{~S}\left(\mathrm{mmol}_{\mathrm{c} \mathrm{dm}}{ }^{-3}\right)$ & 12,9 \\
$\mathrm{Cu}\left(\mathrm{mg} \mathrm{kg}^{-1}\right)$ & 156 \\
$\mathrm{Mn}\left(\mathrm{mg} \mathrm{kg}^{-1}\right)$ & 4.495 \\
$\mathrm{Zn}\left(\mathrm{mg} \mathrm{kg}^{-1}\right)$ & 176 \\
$\mathrm{Fe}\left(\mathrm{mg} \mathrm{kg}^{-1}\right)$ & 2425 \\
$\mathrm{Na}\left(\mathrm{mg} \mathrm{kg}^{-1}\right)$ & 13.772 \\
$\mathrm{Cd}\left(\mathrm{mg} \mathrm{kg}^{-1}\right)$ & 10 \\
$\mathrm{Cr}\left(\mathrm{mg} \mathrm{kg}^{-1}\right)$ & 24.000 \\
\hline
\end{tabular}




\subsection{1 pH em água}

Foram adicionados $25 \mathrm{~mL}$ de água destilada em $10 \mathrm{~g}$ de TFSA e a suspensão agitada em agitador com movimento circular-horizontal por um período de 10 minutos (Brasil, 1983). Após repouso de dez minutos foi realizada a leitura do valor $\mathrm{pH}$ com auxílio de pH-metro CG 841 Schott, com lavagem do eletrodo com água destilada entre as leituras.

\subsubsection{Condutividade elétrica}

A condutividade elétrica das amostras foi determinada fazendo-se a leitura da mesma suspensão obtida para determinação do valor $\mathrm{pH}$ em condutivímetro Tecnopon CA 150.

\subsubsection{Matéria orgânica}

A matéria orgânica foi determinada de acordo com o método colorimétrico descrito em Raij et al. (1987). Um centímetro cúbico de terra é adicionado a $10 \mathrm{~mL}$ de solução de $\mathrm{Na}_{2} \mathrm{Cr}_{2} \mathrm{O}_{7} 4 \mathrm{Ne} \mathrm{H}_{2} \mathrm{SO}_{4} 10 \mathrm{~N}$. A mistura é agitada em agitador com movimento circular-horizontal por um período de 10 minutos. Segundo Raij et al. (1987), esta agitação é suficiente para promover a oxidação da matéria orgânica sem a necessidade de aquecimento. $\mathrm{O}$ íon $\mathrm{Cr}^{3+}$ foi determinado em colorímetro com filtro de transmissão máxima a $650 \mathrm{~nm}$ e o teor de matéria orgânica calculado.

\subsubsection{Número mais provável de bactérias}

A contagem de bactérias foi realizada com a metodologia de contagem em gotas, confome descrito no item 3.1, utilizando-se como meio de cultura o ágar nutriente. 


\subsubsection{Número mais provável de fungos}

A contagem de fungos foi realizada com a metodologia de contagem em gotas, confome descrito no item 3.1, utilizando-se como meio de cultura o meio de Martin sem rosa bengala.

\subsubsection{Número mais provável de microrganismos celulolíticos}

Amostras de solo foram misturadas em solução salina de $\mathrm{NaCl}(0,85 \%)$ e a suspensão diluída até a diluição $10^{-7}$ e $1 \mathrm{~mL}$ de cada diluição foi adicionado a tubo de ensaio contendo meio de cultura (quadro 7) cuja principal fonte de carbono orgânico foi a celulose em forma de tira de papel de filtro (modificado de Burnett et al., 1957). A determinação da presença dos microrganismos foi realizada pela contagem dos tubos nos quais havia crescimento de microrganismos nas tiras de celulose. O número mais provável foi obtido utilizando-se tabela de probabilidade de ocorrência (Tabela de McCrady).

\subsubsection{Número mais provável de microrganismos amonificantes}

A determinação do número mais provável (NMP) de organismos amonificantes foi realizada de maneira semelhante àquela utilizada para microrganismos celulolíticos, transferindo-se da mesma suspensão diluída alíquota de $1 \mathrm{~mL}$ para tubo contendo meio de cultura específico.

Para a deteminação do NMP de organismos amonificantes foi utilizado meio de cultura básico e asparagina como única fonte de nitrogênio (modificado de Bumett et al., 1957). Para cada diluição foram utilizados 4 tubos de ensaio com capacidade de $20 \mathrm{~mL}$, tampados, contendo $5 \mathrm{~mL}$ do meio de cultura (quadro 7) e autoclavados a $110^{\circ} \mathrm{C}(1 \mathrm{~atm})$ por um período de 20 minutos. Os tubos permaneceram por um período de incubação de 6 dias em sala climatizada $\left(28^{\circ} \mathrm{C}\right)$. A presença de amônia foi então determinada pela formação de cor marrom aveludado quando da adição de 
reagente de Nessler. O número mais provável foi obtido através de tabela de probabilidade de ocorrência (Tabela de McCrady).

Quadro 7. Composição dos meios de cultura utilizados para determinação do NMP de organismos amonificantes e celulolíticos.

\begin{tabular}{|ll|}
\hline \multicolumn{1}{|c|}{ Organismos celulolíticos } & Organismos amonificantes \\
\hline $1.000 \mathrm{~mL}$ água & $1.000 \mathrm{~mL}$ água \\
$2,0 \mathrm{~g} \mathrm{~K}_{2} \mathrm{HPO}_{4}$ & $0,5 \mathrm{~g} \mathrm{~K}_{2} \mathrm{HPO}_{4}$ \\
$0,5 \mathrm{~g} \mathrm{MgSO}_{4} \times 7 \mathrm{H}_{2} \mathrm{O}$ & $0,2 \mathrm{~g} \mathrm{MgSO}_{4} \times 7 \mathrm{H}_{2} \mathrm{O}$ \\
$0,5 \mathrm{~g} \mathrm{KCl}$ & $10 \mathrm{~g} \mathrm{NaCl}$ \\
$1,0 \mathrm{~g} \mathrm{NaNO}$ & $0,2 \mathrm{~g}$ asparagina \\
$0,5 \mathrm{~g}$ extrato de levedura & $1 \mathrm{~mL}$ sol. micronutrientes \\
0,5 caseina hidrolizada & $1 \mathrm{~mL}$ Fe EDTA \\
\hline
\end{tabular}

\subsubsection{Produção de $\mathrm{CO}_{2}$}

Amostras de $50 \mathrm{~g}$ de solo e cadinho de vidro, contendo $10 \mathrm{~mL}$ de $\mathrm{NaOH} 0,5 \mathrm{~N}$, foram introduzidos em um jarro de vidro, que foi hermeticamente fechado e mantido em sala climatizada com temperatura constante de $28^{\circ} \mathrm{C}$. A intervalos de 2 dias foram realizadas as determinações de $\mathrm{CO}_{2}$ absorvido pela soda em equipamento FIA, conforme metodologia descrita no item 3.2. Após cada leitura a soda foi substituída e o frasco novamente fechado.

\subsubsection{Biomassa microbiana}

A biomassa microbiana foi avaliada pelo método fumigação-extração (Vance et al., 1987) comparando-se a quantidade de carbono extraído de amostra esterilizada com uma não esterilizada.

Para cada amostra a ser analisada, foram realizadas 2 sub-amostras de 10 gramas colocadas em cadinho de vidro. A primeira sub-amostra foi fumigada em 
dessecador contendo um Becker com pérola de vidro e clorofórmio. O clorofórmio foi evaporado com auxílio de bomba a vácuo. Após um período de 24 horas, promoveu-se a retirada do resíduo de clorofórmio do dessecador, novamente com o auxílio da bomba a vácuo. Ambas sub-amostras receberam então $40 \mathrm{~mL}$ de $\mathrm{K}_{2} \mathrm{SO}_{4} 0,5 \mathrm{M}$ e os cadinhos foram agitados por um período de 30 minutos em agitador horizontal. A suspensão resultante foi então filtrada em papel de filtro Whatman $\mathrm{n}^{\circ} 1$.

O carbono orgânico dos extratos das duas sub-amostras foi determinado por digestão com dicromato de potássio $\left(\mathrm{K}_{2} \mathrm{Cr}_{2} \mathrm{O}_{7}\right)$, ácido sulfúrico concentrado e ácido fosfórico $\left(\mathrm{H}_{3} \mathrm{PO}_{4}\right)$ em banho maria por uma hora e, após resfriado, titulado com sulfato ferroso de amônio utilizando difenilamina sulfonato de bário como indicador.

\subsubsection{Degradação de celulose}

Foi avaliada através de método gravimétrico. Círculos de papel de filtro com $4 \mathrm{~cm}$ de diâmetro, após secagem em estufa a $65^{\circ} \mathrm{C}$, foram tarados e incubados com 20 gramas de terra por um período de 4 semanas em placas de vidro umedecidas regularmente e mantidas em ambiente de temperatura constante a $28^{\circ} \mathrm{C}$ (Institut für Bodenkunde der Universität Bonn, 1992).

Após o período de incubação, o papel de filtro foi cuidadosamente lavado, seco em estufa a $65^{\circ} \mathrm{C}$, tarado e, finalmente, encaminhado para mufla em cadinho de porcelana para se obter o peso de cinzas. O consumo de celulose foi obtido pela diferença do peso do papel de filtro antes e depois do período de incubação. A pureza do papel em celulose pôde ser obtida através da incineração de amostras de papel de filtro. 


\section{RESULTADOS E DISCUSSÃO}

\subsection{Avaliação da metodologia de plaqueamento de gotas}

4.1.1 Experimento I: Comparação entre a metodologia tradicional e a metodologia proposta.

Os resultados obtidos (figura 3) mostram que para bactérias as contagens foram da ordem de $10^{6}$ e para fungos de $10^{4}$ para ambos os métodos empregados. Os dados foram transformados em log NMP para que fossem atendidas as pressuposições da análise de variância, conforme sugestão do sistema estatístico SAS. Apesar de a contagem através do método de plaqueamento de gotas, ser ligeiramente superior aos resultados obtidos pela contagem tradicional de diluição e plaqueamento, esta diferença não é estatisticamente significativa. Através da análise de variância não se verificou diferença significativa entre os dois métodos, tanto para fungos como para bactérias.

Verificada a possibilidade de substituição do método tradicional de diluição e plaqueamento pelo método de plaqueamento de gotas, foram realizados os seguintes experimentos com o objetivo de verificar se a metodologia proposta fornece resultados semelhantes em solos de diferentes texturas, na presença de desagregantes durante a diluição da amostra e, por fim, se o método proposto responde a alterações ambientais tais como a adição de metal pesado e/ou matéria orgânica. 


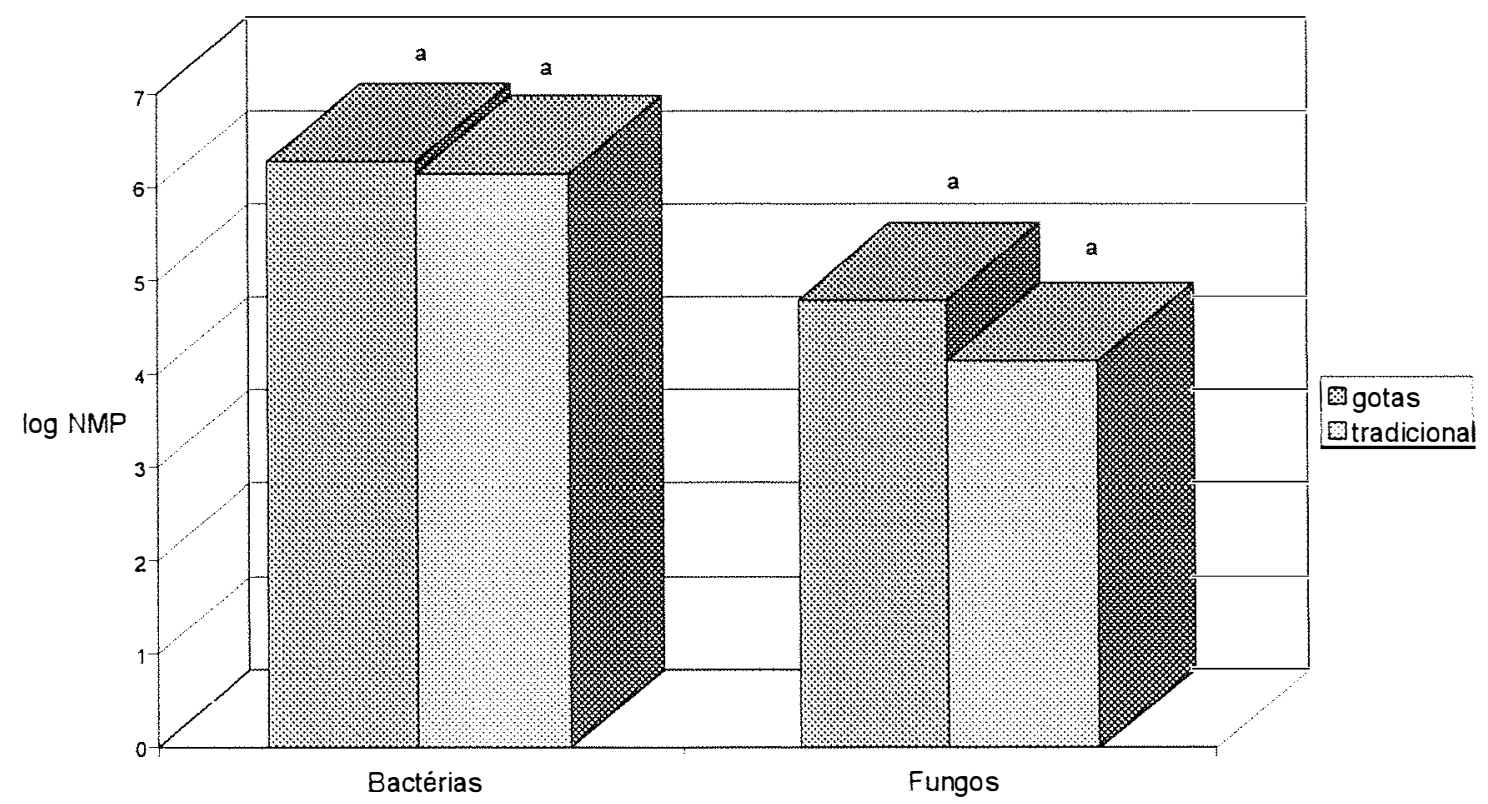

Letras nas colunas comparam os métodos de determinação entre si pelo teste de Tukey ao nível de 0,05 de probabilidade.

Figura 3. NMP de bactérias e fungos em amostra de solo, obtido através do método de plaqueamento de gotas e tradicional.

4.1.2 Experimento II: Avaliação das metodologias de quantificação de microrganismos em amostras de solo de diferentes texturas.

Neste experimento foi avaliado se haveria efeito da textura do solo sobre o método de contagem de microrganismos. Foram comparadas a metodologia tradicional e a metodologia proposta em amostras de três solos de texturas distintas. Os resultados da análise estatística estão mostrados nas tabelas 1 e 2. Para os dados referentes à contagem de bactérias foi feita a transformação $\mathrm{NMP}^{\mathbf{0}, 3}$, e para os dados de contagem de fungos, a transformação para log NMP, conforme sugestão do programa estatístico SAS para estabelecer as condições necessárias para a realização da análise de variância.

Neste experimento ocorreu efeito significativo do método empregado e do solo, não ocorrendo, no entanto, interação entre a textura do solo e o método de contagem empregado, o que significa que a textura não interfere na metodologia de 
avaliação de microrganismos. Interessante, no entanto, é que, independentemente do método empregado, a amostra de número 2 foi a que apresentou menor número de bactérias em ambos os métodos empregados, ou seja, ambos os métodos foram capazes de identificar qual solo possuía menor número de microrganismos (figura 4).

Para fungos percebe-se que em todas as amostras de solo estudadas e independentemente do método utilizado, o número de microrganismos está entre $10^{3} \mathrm{e}$ $10^{4}$ organismos por grama de solo (figura 5 ).

Tabela 1. Análise de variância para a variável dependente log NMP de bactérias

\begin{tabular}{lcrl}
\hline Fonte de variação & QM & \multicolumn{1}{c}{$\mathrm{F}$} & $\mathrm{Pr}>\mathrm{F}$ \\
\hline METODO & 1 & 20.13 & 0.0002 \\
SOLO & 2 & 106.77 & 0.0001 \\
MÉTODO*SOLO & 2 & 0.78 & 0.4697 \\
\hline
\end{tabular}

C.V. $=13,21$

Tabela 2. Análise de variância para a variável dependente log NMP de fungos

\begin{tabular}{lccc}
\hline Fonte de variação & QM & $\mathrm{F}$ & $\mathrm{Pr}>\mathrm{F}$ \\
\hline MÉTODO & 1 & 43.01 & 0.0001 \\
SOLO & 2 & 9.52 & 0.0010 \\
MÉTODO*SOLO & 2 & 1.19 & 0.3214 \\
\hline
\end{tabular}

C.V. $=6,76$

As tabelas 1 e 2 mostram que, apesar de existir efeito do método empregado para a determinação do NMP tanto de bactérias como de fungos, não houve interação com os solos estudados.

Diferentemente do que foi obtido com o experimento $I$, quando não foi observada diferença entre os métodos de contagem, neste experimento, a técnica de plaqueamento de gotas proporcionou o crescimento de maior número de microrganismos, mostrando que pode responder de forma mais eficiente à alterações ambientais que o método tradicional de contagem de microrganismos. 


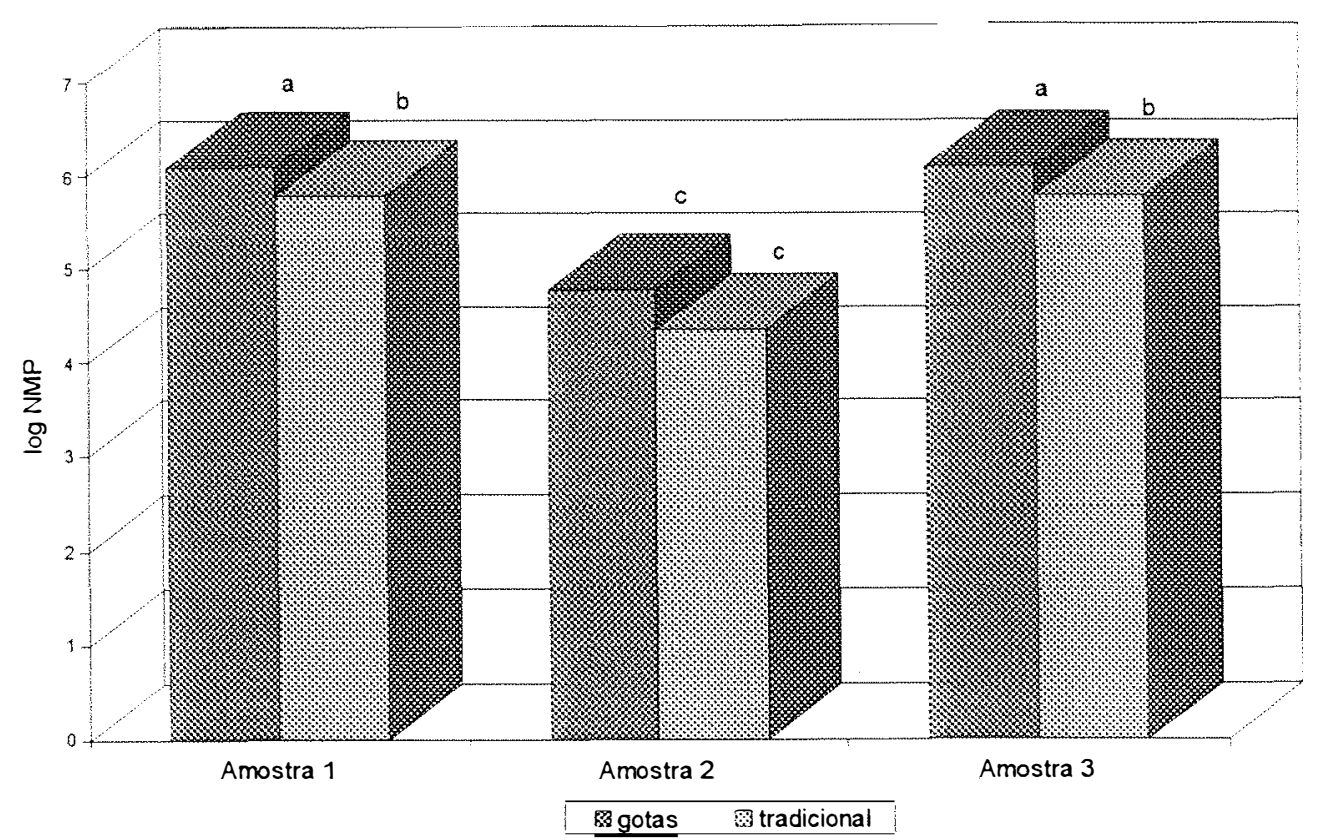

Colunas seguidas por letras iguais não diferem significativamente entre si pelo teste de Student ao nivel de 0,05 de probabilidade.

Figura 4. NMP de bactérias em amostras de três solos de diferentes texturas determinados pelo método de plaqueamento de gotas e tradicional.

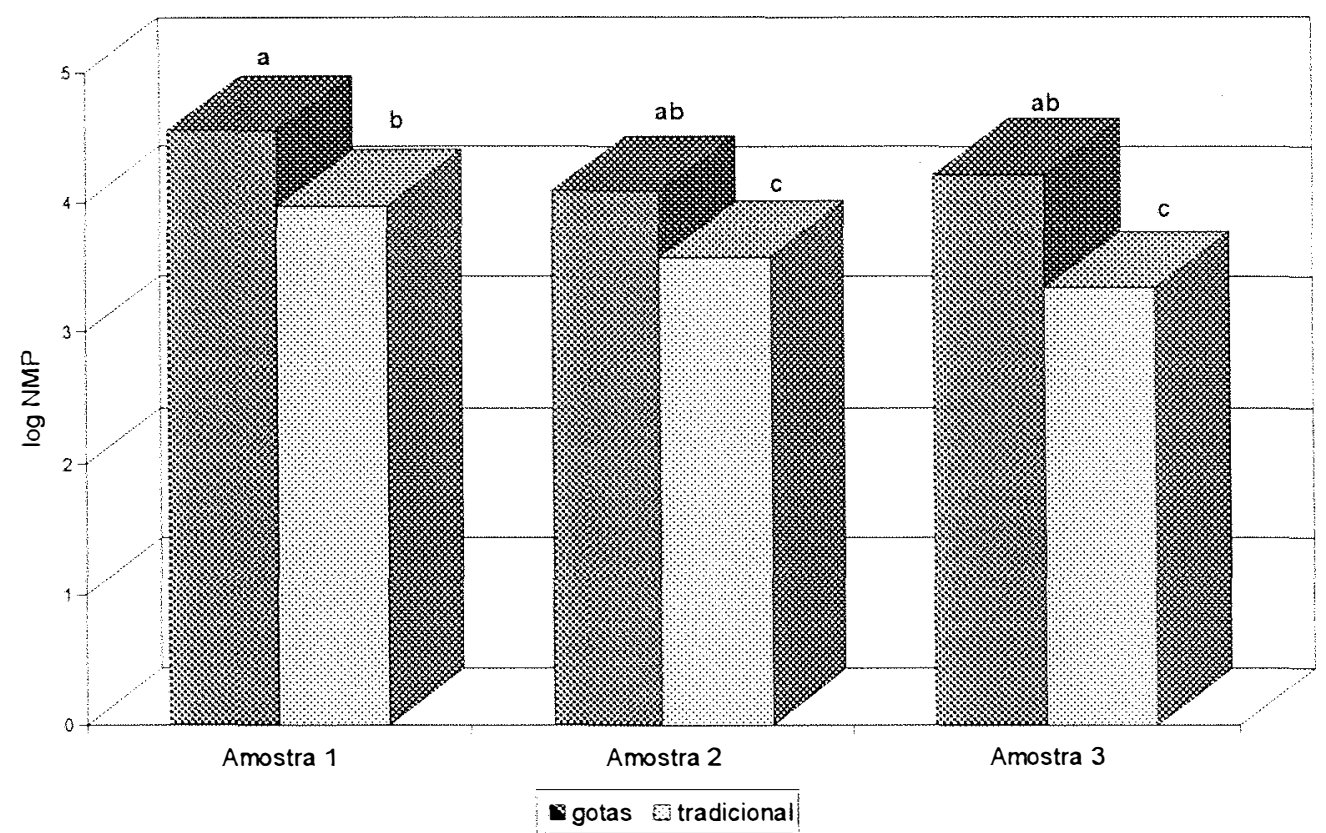

Colunas seguidas por letras iguais não diferem significativamente entre si pelo teste de Student ao nivel de 0,05 de probabilidade.

Figura 5. NMP de fungos em amostras de três solos de diferentes texturas determinados pelo método de plaqueamento de gotas e tradicional. 
4.1.3 Experimento III: Avaliação do efeito de agentes desagregantes.

Neste experimento foi avaliado o efeito de desagregantes durante a primeira diluição da amostra de solo. Pretendeu-se avaliar o efeito do uso de desagregantes sobre a contagem de microrganismos pela técnica de plaqueamento de gotas. Para atender as exigências da análise estatística, os dados obtidos foram transformados em 1/NMP, conforme sugerido pelo programa estatístico SAS. Na determinação do NMP de fungos não ocorreu nenhuma diferença decorrente do uso de desagregante. Já para a contagem de bactérias, verificou-se que o uso de esfera de vidro aumentou significativamente o número final obtido (figura 6).

As bactérias possuem tamanho bastante próximo aos das partículas de argila (aproximadamente $2 \mu \mathrm{m}$ ). Segundo Tsai et al. (1992), existe a possibilidade de aderência de até $90 \%$ dos microrganismos do solo às partículas de argila, com preponderância de bactérias gram-positivas.

Segundo Cochran ${ }^{2}$ citado por Andrade \& Hamakawa (1994), o método de quantificação de microrganismos através do NMP parte do princípio de que os organismos na solução possuem distribuição homogênea e aleatória. $O$ uso de desagregantes tem como função destruir agregados que poderiam estar ocluindo microrganismos. Pelo seu tamanho, os talos bacterianos têm muito mais chance de se encontrarem oclusos dentro de agregados do solo que os esporos fúngicos; estes, por apresentarem tamanho superior ao talo bacteriano, não foram afetados pela destruição de agregados.

Em alguns casos, como no estudo de microrganismos da rizosfera de gramíneas, deve-se levar em consideração a grande produção de gomas que favorecem a formação de agregados e estes, por sua vez, podem ocultar um número relativamente grande de talos bacterianos.

\footnotetext{
${ }^{2}$ COCHRAN, W.C. Estimation of bacterial densities by means of the "most probable number."

Biometrics, v. 6, p. 105-116, 1950.
} 


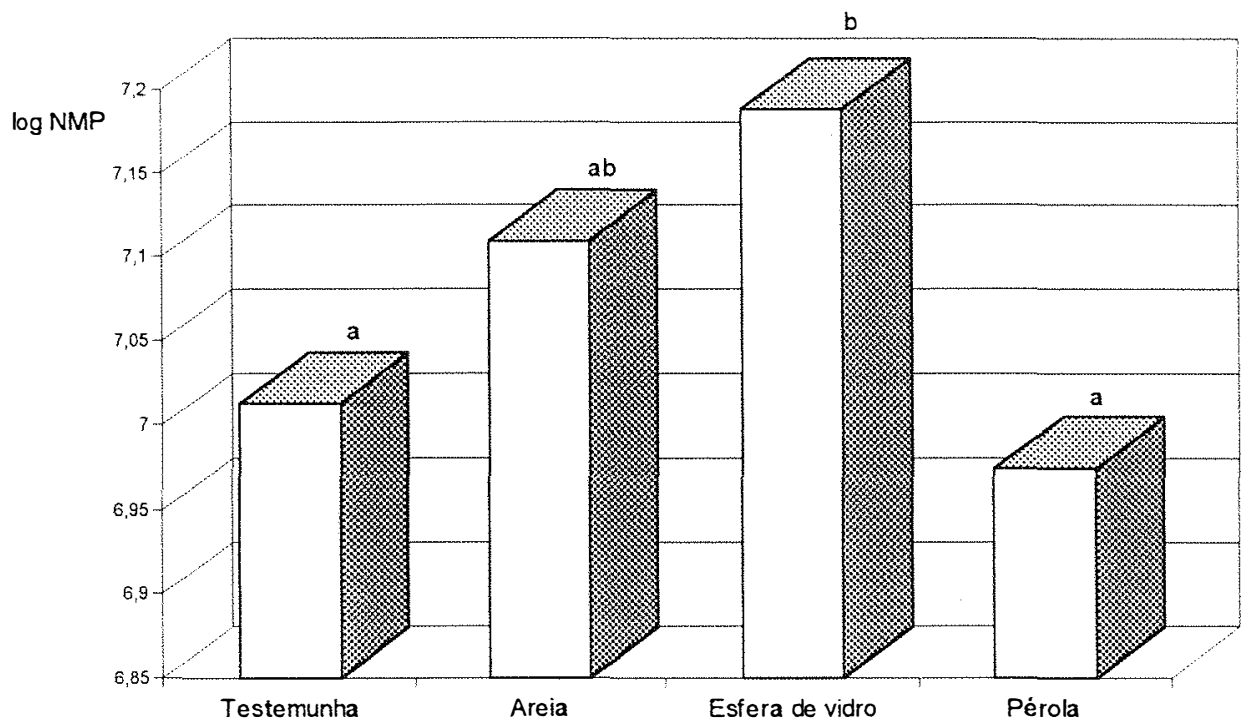

Médias seguidas por letras iguais não diferem significativamente entre si ao nível de 0,05 de probabilidade pelo teste de Student.

Figura 6. NMP de bactérias em amostra de solo, função do uso de diferentes desagregantes durante a primeira diluição, determinadas pelo método de plaqueamento de gotas.

4.1.4 Experimento IV: Verificação da sensibilidade da metodologia proposta a diferentes fontes de matéria orgânica e à presença de crômio na forma de sal.

Para a realização da análise estatística, os dados obtidos foram transformados segundo a expressão log NMP, conforme sugestão do programa estatístico SAS, para que fossem atendidas as condições da análise de variância.

Os dados para contagem de bactérias mostram que não houve efeito do tempo de incubação sobre o número de bactérias. Já a adição de sal de crômio diminuiu significativamente o número de bactérias por grama de solo enquanto os fungos mostraram maior tolerância e não tiveram seu número reduzido pela adição de crômio (figuras 7 e 8). A redução do número de bactérias em amostras de solo que receberam sal de crômio também foi observada por Ueda et al. (1988b). A adição de matéria orgânica favoreceu o aumento no número de bactérias mesmo na presença de sal de crômio. A 
permanência do mesmo número de bactérias em solos contaminados por metal quando comparadas à testemunha não significa que não esteja ocorrendo efeito prejudicial sobre estes organismos. Pode estar ocorrendo diminuição no número de microrganismos sensíveis ao crômio e um acréscimo no número de indivíduos resistentes (Doelman \& Haanstra, 1979; Ueda, et al., 1988a).

Os dados obtidos sugerem maior tolerância dos fungos quando comparados às bactérias, diferentemente do que foi encontrado por Ueda et al. (1988b). No entanto, não se deve acreditar que a manutenção do mesmo número de microrganismos em amostras de solo que receberam sal de crômio seja um sinal de que o metal seja inócuo aos microrganismos. Alterações no nível de atividade metabólica ou modificações na composição da comunidade do solo podem estar ocorrendo sem que a contagem final de microrganismos seja afetada ou alterada.

A maior parte das observações permaneceu na ordem de $10^{5}$ unidades formadoras de colônias (UFC) para bactérias e de $10^{4}$ para fungos por grama de terra. Os tratamentos que receberam crômio na forma de sal foram os que apresentaram menor número de bactérias por grama de solo, diferindo de todos os demais tratamentos com 0,01 de probabilidade.

É interessante observar que a presença de bagaço de cana e de composto diminuiu o efeito prejudicial do crômio por favorecer o crescimento de maior número de microrganismos ou mesmo por diminuir a disponibilidade do crômio através do aumento da CTC ou da formação de complexos de crômio com a matéria orgânica. Deve-se considerar que a adição de matéria orgânica estimula a multiplicação de microrganismos e que a presença do sal de crômio atuou como inibidor deste crescimento ou mesmo como fator de seleção. Os tratamentos que não receberam sal de crômio não apresentaram diferenças significativas entre si para NMP de bactérias.

Não se observou redução no NMP de fungos em solos que receberam somente crômio quando comparados com a testemunha (figura 8). No entanto, foi observado aumento no número de fungos quando da adição de bagaço ou de composto. Não houve diferença na contagem de fungos entre os tratamentos que receberam matéria orgânica com aqueles que receberam matéria orgânica e sal de crômio. Já o tratamento 
que só recebeu sal de crômio apresentou menor número de fungos durante todo o período de incubação. As diferenças existentes neste tratamento no início e no final do experimento não são estatisticamente significativas.

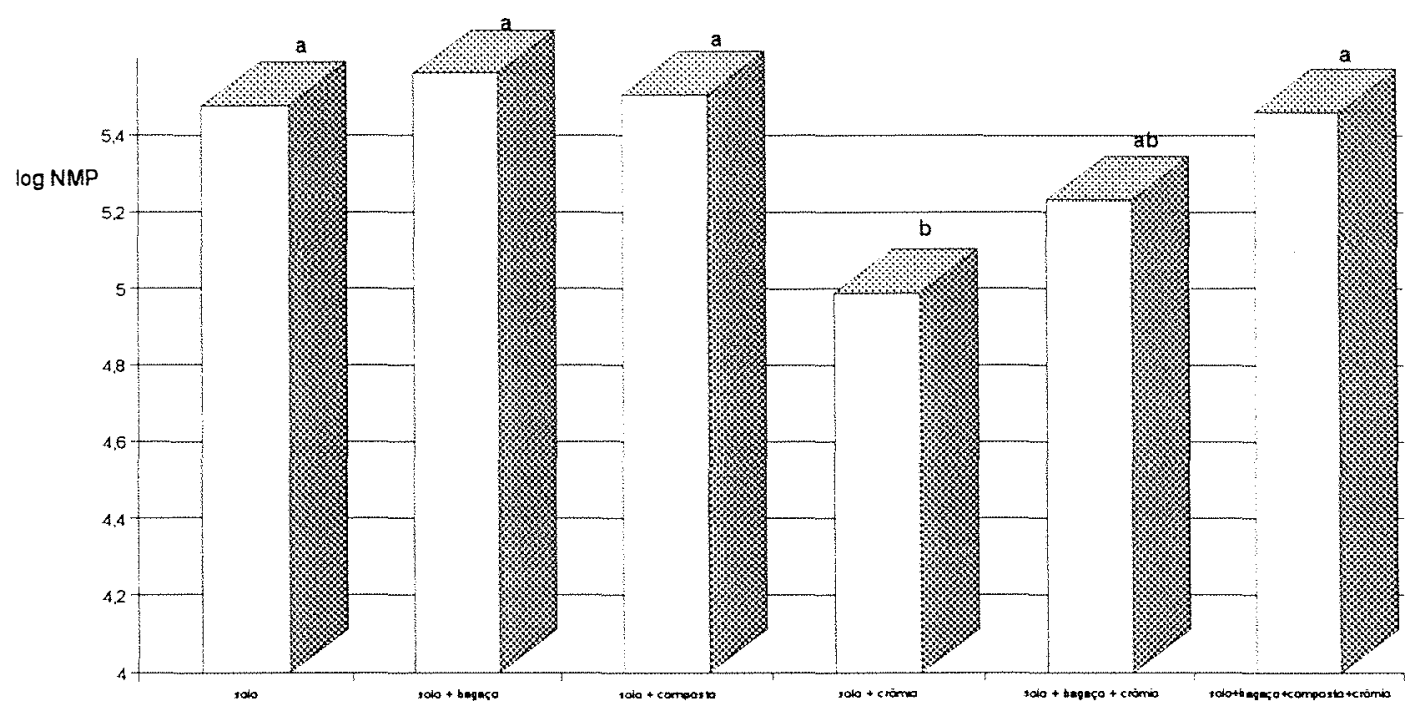

Médias seguidas por letras iguais não diferem significativamente entre si ao nível de 0,05 de probabilidade pelo teste de Student.

Figura 7. NMP de bactérias em amostras de solo que receberam resíduo orgânico e sal de crômio.

Estes resultados mostram que é possível avaliar os efeitos da adição de matéria orgânica, metais pesados e da sua interação sobre o ecossistema solo através da contagem de microrganismos. No entanto a resposta de microrganismos à adição de metais pesados na forma de sais inorgânicos aplicados diretamente ao solo ou ao lodo provavelmente não reflita o que ocorreria com a aplicação de lodo de esgoto, pois os metais no lodo estão na sua maior parte indisponíveis pela formação de complexos organo-metálicos insolúveis (Smith, 1991). 


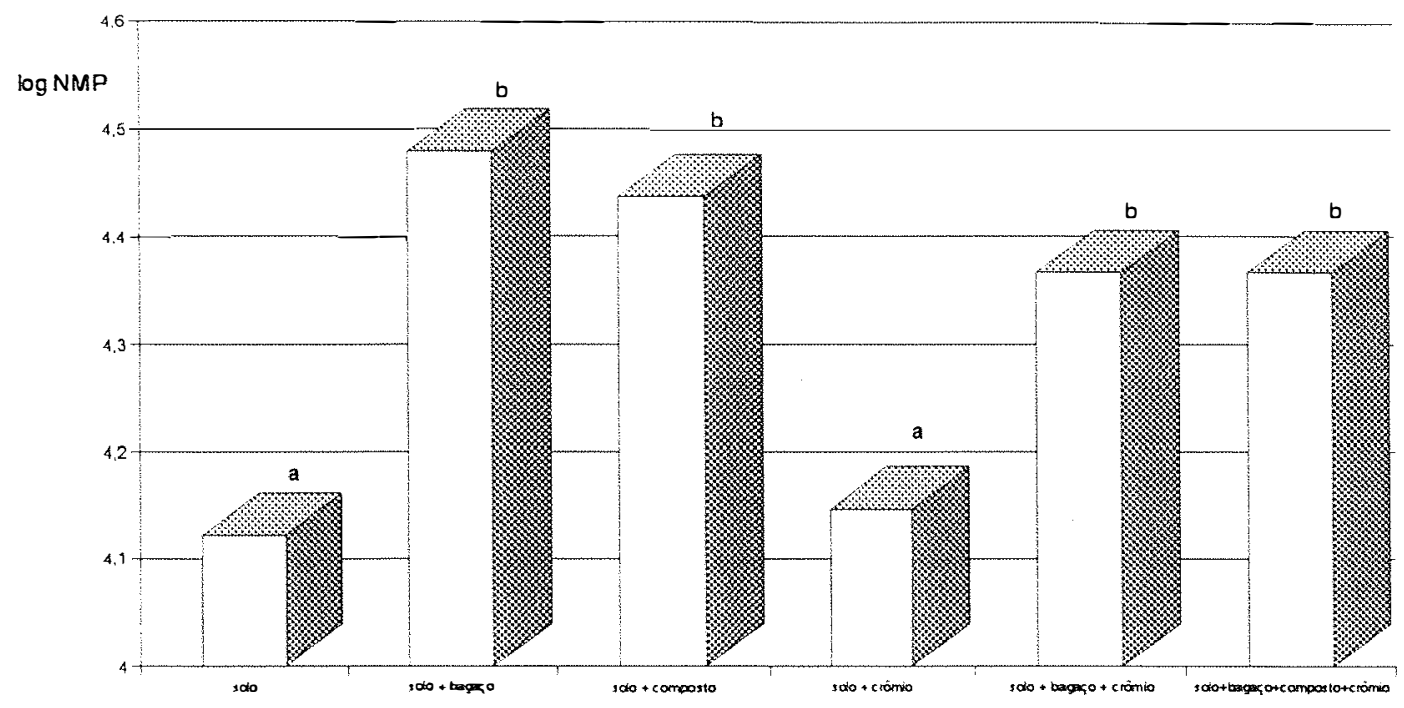

Médias seguidas por letras iguais não diferem significativamente entre si ao nível de 0,05 de probabilidade pelo teste de Student.

Figura 8. NMP de fungos em amostras de solo que receberam resíduo orgânico e sal de crômio.

\subsection{Estudo da degradação de lodo de curtume}

Neste experimento foi estudada, através de parâmetros microbiológicos, a degradação no solo de lodo de esgoto proveniente da indústria de processamento de couro, naturalmente rico em metais pesados, especialmente o crômio (quadro 6).

\subsection{1 pH em água}

As alterações no valor de $\mathrm{pH}$ nas amostras de solo arenoso e argiloso, em função da aplicação do resíduo orgânico, podem ser vistas nas figuras 9 e 10 , respectivamente. Pode ser verificado que a um aumento na dose aplicada corresponde a elevação do valor $\mathrm{pH}$ em ambos os solos. Esta elevação no valor de $\mathrm{pH}$ também foi 
observada por Korcak et al. (1979) após aplicar lodo de esgoto em amostras de solo, por Amaral Sobrinho et al. (1993) ao utilizar lodo ativado proveniente de usina siderúrgica, e por Castilhos et al. (1997) ao utilizar resíduo de curtume como fertilizante.

Deve se notar que foram necessários aproximadamente 20 dias para que se iniciassem as mudanças no valor do $\mathrm{pH}$, e que estas mudanças continuaram a ocorrer ao longo do período de incubação, mostrando que o equilíbrio ainda não havia sido atingido durante o período estudado.

A elevação do valor do $\mathrm{pH}$ com a utilização de lodo de curtume reduz a mobilidade de metais pesados e diminui, desta maneira, sua disponibilidade aos microrganismos. De forma geral, metais pesados são mais móveis em condições de acidez, e a elevação do $\mathrm{pH}$ através do uso de calcário reduz a sua biodisponibilidade (Alloway, 1990). Em solos extremamente ácidos, a atividade da micro e mesofauna do solo é limitada de tal forma que o processo de mineralização da matéria orgânica e da biomassa microbiana passa a ocorrer de forma lenta. Ou seja, o aumento do $\mathrm{pH}$ favorece o processo de mineralização (Scheffer \& Schachtschabel, 1992).

Para a mesma dose de lodo aplicado, o pH do solo arenoso, embora mais ácido, foi sempre superior àquele observado no solo argiloso, o que pode ser atribuído a menor poder tampão apresentado pelo solo arenoso. Com a mesma dose de lodo aplicada, existem diferenças no valor $\mathrm{pH}$ e, por conseguinte, diferenças na biodisponibilidade de metais pesados, fato este que pode ajudar a explicar o maior número de microrganismos nas amostras de solo arenoso.

A habilidade da fração sólida do solo em adsorver íons varia bastante em função da natureza do material, mas é também fortemente influenciada pelas condições de oxiredução e pelo valor $\mathrm{pH}$, além da concentração relativa dos íons presentes na solução do solo. As variações nos teores de umidade, $\mathrm{pH}$ e condições de oxiredução do solo resultam em alterações na biodisponibilidade de metais pesados para microrganismos e plantas. Nos tratamentos que não receberam lodo observou-se um processo de acidificação ao longo do período de incubação, possivelmente devido ao excesso de irrigação. 


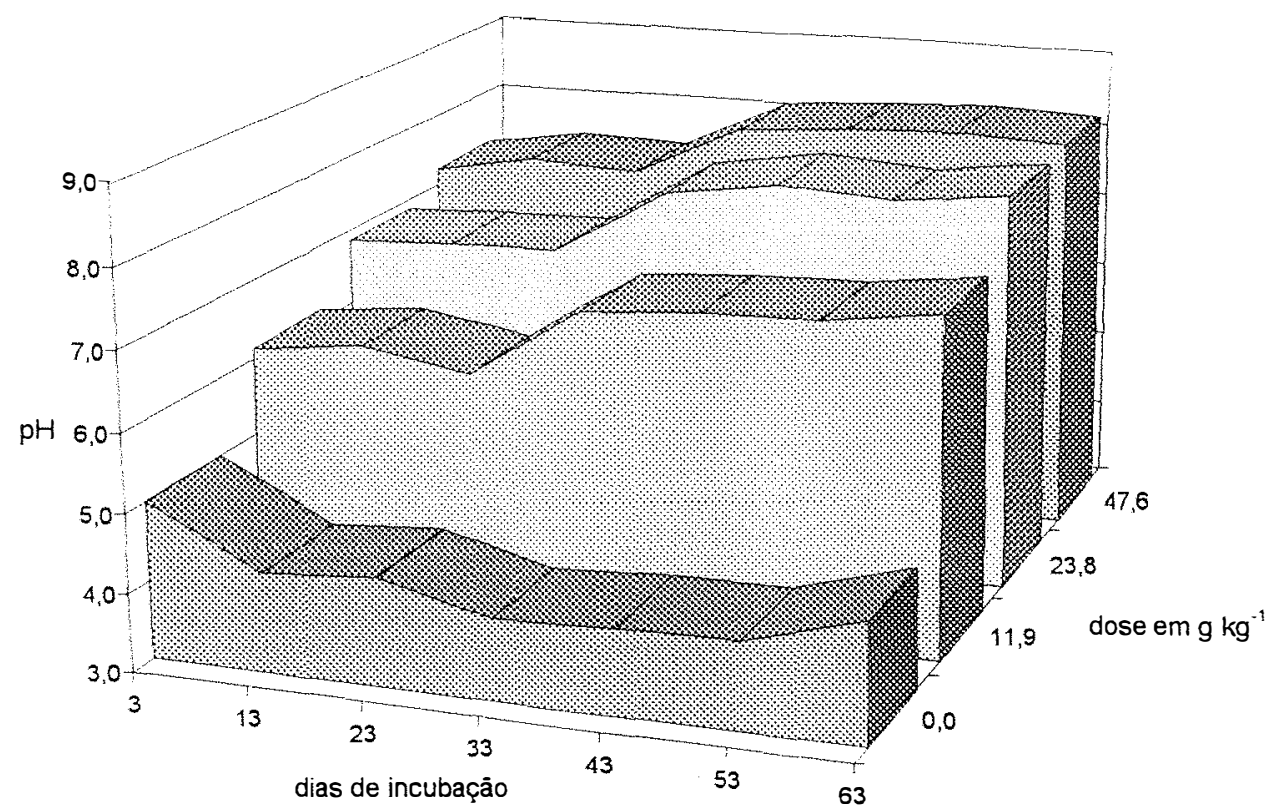

Figura 9. Variação do pH de um solo arenoso em função das doses de lodo de curtume e do período de incubação.

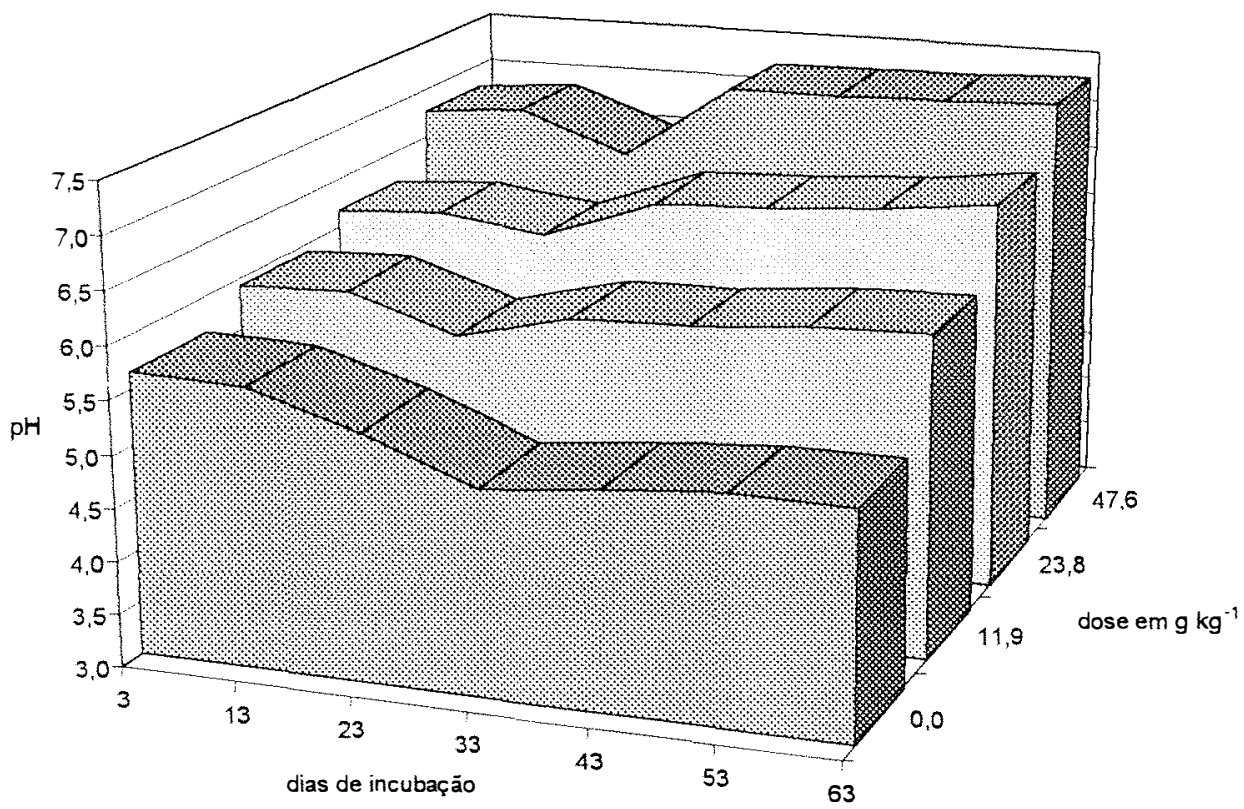

Figura 10. Variação do pH de um solo argiloso em função das doses de lodo de curtume e do período de incubação. 
Munier-Lamy et al. (1991) afirmam que a mobilidade de metais pesados no solo e sua transferência para plantas não depende somente das propriedades químicas do elemento e dos processos fisico-químicos tais como adsorção, complexação e troca iônica, mas também da atividade microbiana. Segundo estes autores, agentes quelantes, tais como ácidos orgânicos, exudados na rizosfera ou provenientes da atividade microbiana, são capazes de formar complexos químicos estáveis com os metais pesados. Os autores afirmam que esta habilidade está relacionada com a afinidade dos ligantes, com a natureza do metal e com o íon $\mathrm{H}^{+}$e, conseqüentemente, com o pH do solo. Por outro lado, os complexos orgânicos formados podem se desestabilizar quando o carbono dos agentes ligantes for consumido pelos microrganismos, fazendo com que o metal seja precipitado na forma de hidróxidos e/ou absorvido por microrganismos.

A ausência de efeitos decorrentes da presença do crômio no resíduo de curtume também pode ser explicada pela quase insolubilidade do $\mathrm{Cr}$ (VI) em valores de pH situados entre 6 e 8, quando da presença de Al na solução (Bartlett \& Kimble, 1976b).

\subsubsection{Condutividade elétrica}

Para que fossem atendidos os requisitos da análise de variância, os dados de condutividade elétrica foram transformados segundo a relação $(\mu \mathrm{S} / \mathrm{cm})^{\bullet, 3}$, conforme sugestão do programa estatístico SAS. Para condutividade foi observado efeito significativo de dosagem, época, solo e das interações dose x época x solo. 


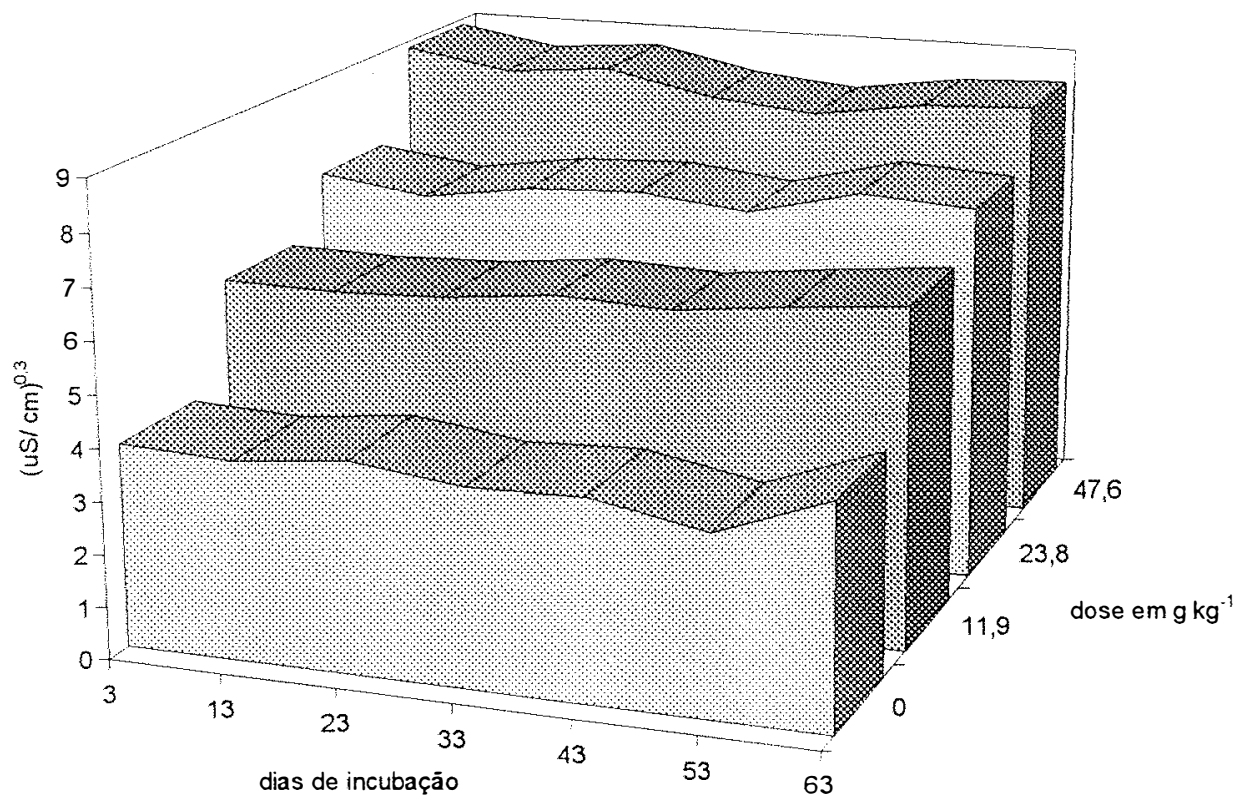

Figura 11. Condutividade elétrica de um solo arenoso em função das doses de lodo de curtume e do período de incubação.

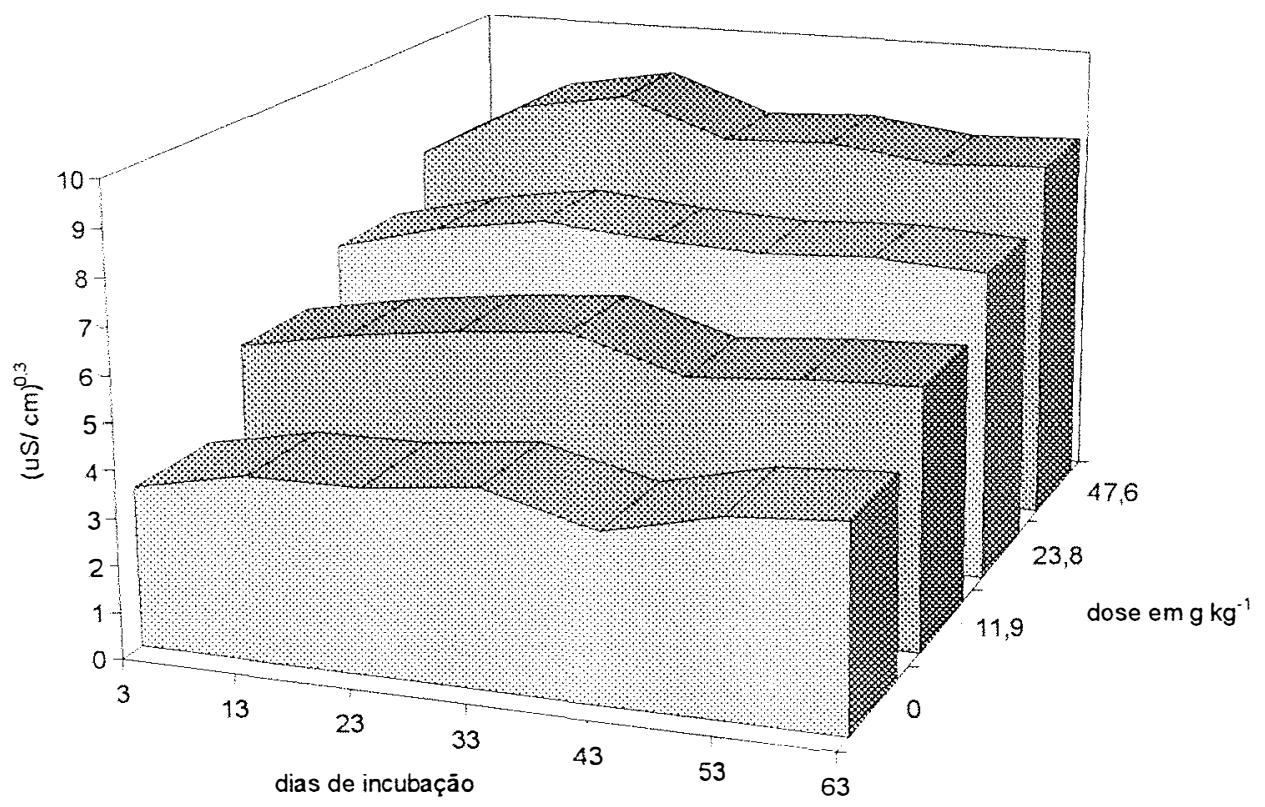

Figura 12. Condutividade elétrica de um solo argiloso em função das doses de lodo de curtume e do período de incubação. 
A observação das figuras 11 e 12 permite verificar que um aumento na dose de lodo adicionado corresponde a um aumento na condutividade elétrica. $\mathrm{O}$ resultado da análise estatística mostra que as diferenças entre as doses são significativas. $\mathrm{E}$ da mesma maneira como ocorreu com o valor $\mathrm{pH}$, foi necessário um período de tempo para que ocorressem as reações de equilíbrio. Os elevados teores de sais solúveis, principalmente a presença de sódio no lodo de curtume (quadro 6), foram os responsáveis pela elevação da condutividade elétrica das amostras de solo estudadas o que se constitui em sério problema para o cultivo de plantas.

\subsubsection{Matéria orgânica}

O elevado teor de matéria orgânica existente no lodo aplicado (quadro 6) possivelmente auxiliou na redução do efeito tóxico do crômio. No entanto, a adição contínua de lodo de curtume, associada com a oxidação da matéria orgânica, poderia acentuar os efeitos prejudiciais decorrentes da presença de metais pesados.

Através do quadro 4, pode-se verificar que a amostra de solo argiloso utilizada tem exatamente o dobro de matéria orgânica da amostra de solo arenoso. No entanto, ao longo do período de incubação houve tendência de aproximação destes valores. Isto ocorre pela oxidação da matéria orgânica em função das condições de elevada temperatura e umidade pela qual é conduzido o experimento, mostrando que não ocorreu nenhuma inibição ao processo de oxidação da matéria orgânica causado pela presença do crômio, fato este também observado por Benedetti et al. (1991), ao estudar a degradação de resíduos de curtume.

As tabelas 3 e 4 mostram os teores de matéria orgânica para os solos arenoso e argiloso, respectivamente, ao longo do período de incubação. 
Tabela 3. Teor de matéria orgânica em função de dose de lodo e do período de incubação em solo arenoso.

\begin{tabular}{llllllll}
\hline & \multicolumn{7}{c}{ Dias de incubação } \\
\hline Dose $\mathrm{g} \mathrm{kg}^{-1}$ & 3 & 13 & 23 & 33 & 43 & 53 & 63 \\
\hline 0 & $1,211 \mathrm{a}$ & $1,168 \mathrm{a}$ & $1,197 \mathrm{a}$ & $1,127 \mathrm{a}$ & $1,604 \mathrm{a}$ & $1,155 \mathrm{a}$ & $1,167 \mathrm{a}$ \\
11,9 & $1,341 \mathrm{~b}$ & $1,210 \mathrm{a}$ & $1,414 \mathrm{~b}$ & $1,221 \mathrm{a}$ & $1,699 \mathrm{a}$ & $1,220 \mathrm{a}$ & $1,233 \mathrm{a}$ \\
23,8 & $1,376 \mathrm{~b}$ & $1,409 \mathrm{~b}$ & $1,494 \mathrm{~b}$ & $1,329 \mathrm{~b}$ & $1,328 \mathrm{~b}$ & $1,351 \mathrm{~b}$ & $1,351 \mathrm{~b}$ \\
47,6 & $1,581 \mathrm{c}$ & $1,494 \mathrm{~b}$ & $1,751 \mathrm{c}$ & $1,649 \mathrm{c}$ & $1,463 \mathrm{c}$ & $1,463 \mathrm{c}$ & $1,515 \mathrm{c}$ \\
\hline
\end{tabular}

Comparar letras na vertical.

Médias seguidas de letras iguais não diferem entre si, ao nivel de 0,05 de probabilidade pelo teste de Student.

Tabela 4. Teor de matéria orgânica em função de dose de lodo e do período de incubação em solo argiloso.

\begin{tabular}{llllllll}
\hline & \multicolumn{7}{c}{ Dias de incubaçã } \\
\hline Dose $\mathrm{g} \mathrm{kg}^{-1}$ & 3 & 13 & 23 & 33 & 43 & 53 & 63 \\
\hline 0 & $1,653 \mathrm{a}$ & $1,527 \mathrm{a}$ & $1,897 \mathrm{a}$ & $1,804 \mathrm{a}$ & $1,546 \mathrm{a}$ & $1,505 \mathrm{a}$ & $1,544 \mathrm{a}$ \\
11,9 & $1,788 \mathrm{~b}$ & $1,652 \mathrm{a}$ & $1,966 \mathrm{a}$ & $1,154 \mathrm{~b}$ & $1,613 \mathrm{ab}$ & $1,594 \mathrm{a}$ & $1,623 \mathrm{a}$ \\
23,8 & $1,825 \mathrm{~b}$ & $1,580 \mathrm{a}$ & $2,159 \mathrm{~b}$ & $1,303 \mathrm{c}$ & $1,679 \mathrm{bc}$ & $1,679 \mathrm{~b}$ & $1,620 \mathrm{a}$ \\
47,6 & $1,889 \mathrm{~b}$ & $1,823 \mathrm{~b}$ & $2,265 \mathrm{~b}$ & $1,509 \mathrm{~d}$ & $1,735 \mathrm{c}$ & $1,715 \mathrm{~b}$ & $1,796 \mathrm{~b}$ \\
\hline
\end{tabular}

Comparar letras na vertical.

Médias seguidas de letras iguais não diferem entre si, ao nivel de 0,05 de probabilidade pelo teste de Student.

Diversos autores verificaram que a presença de matéria orgânica favorece o crescimento da comunidade e a atividade de microrganismos do solo (Chang \& Broadbent, 1981; Lindemann et al. 1984; Lopes et al., 1986; Hattori, 1987; Sutton et al., 1991; Eivazi \& Zakaria, 1992; Smith \& Hadley, 1992; Chander et al., 1995), proporcionando nutrientes e energia, além de reduzir os efeitos inibitórios de metais pesados sobre a microbiota do solo (Hattori, 1989; Eivazi \& Zakaria, 1993).

A disponibilidade de metais pesados no solo é afetada pela adsorção dos íons metálicos à superficie dos colóides e pela formação de quelatos com a matéria orgânica. Compostos orgânicos de baixo peso molecular, não necessariamente húmicos, podem formar complexos solúveis com metais pesados, evitando que sejam absorvidos ou precipitados. Os compostos húmicos com grupos reativos disponiveis, tais como, hidroxila, fenólico ou carboxílico, são capazes de formar complexos com íons metálicos (Alloway, 1993). A formação de quelatos com matéria orgânica é um dos mais 
importantes mecanismos no controle da disponibilidade de metais pesados para plantas e microrganismos (Munier-Lamy et al., 1991).

\subsubsection{Número mais provável de bactérias}

Para a realização da análise estatística do NMP dos grupos de microrganismos estudados, foi realizada a transformação dos dados obtidos para log NMP para que fossem atendidas as pressuposições da análise de variância conforme sugestão do sistema estatístico SAS.

As figuras 13 e 14 mostram graficamente os dados de contagem de bactérias encontrados nas amostras de solo arenoso e argiloso, em função do tempo de incubação e da dose de lodo. Através da comparação de médias realizada pelo teste $t$ de Student a 0,05 de probabilidade, verifica-se a existência de diferença estatisticamente significativa para contagem de bactérias entre os solos.

No entanto, na primeira data de coleta, não se observaram diferenças significativas entre as doses estudadas dentro do mesmo tipo de solo, possivelmente devido à existência de uma fase lag (lag-phase) quando os microrganismos se adaptam às novas condições ambientais impostas pelo experimento. Esta fase é caracterizada pela ocorrência de nenhum ou pequeno crescimento de microrganismos (Sistrom, 1973).

A partir da leitura realizada aos 13 dias de incubação, já se observam diferenças estatisticamente significativas entre as doses estudadas. Observa-se também que as parcelas que não receberam lodo de esgoto não apresentaram alterações significativas no NMP de bactérias ao longo do período de incubação.

Foi observado também que o solo arenoso apresentou um número de bactérias superior àquele observado em solo argiloso, com exceção da dose zero. Nesta dose, o NMP de bactérias do solo arenoso é menor do que o encontrado em solo argiloso, possivelmente em função do maior teor de matéria orgânica encontrada no solo argiloso (quadro 4).

A partir da segunda coleta, o solo arenoso apresentou um número significativamente maior de bactérias que o argiloso. Enquanto no solo argiloso a média 
do número de bactérias ficou em $10^{5,85}$, este valor subiu para $10^{6,22}$ em solo arenoso. Esta diferença pode ser talvez atribuída à melhor homogeneização da matéria orgânica em amostras de solos arenosos e a maior disponibilidade de oxigênio.

Apesar da presença de metais pesados, a adição de matéria orgânica através da aplicação de lodo favoreceu a multiplicação de bactérias no solo. Este fato também foi observado por Brendecke et al. (1993), que não encontraram efeitos adversos da presença de metais pesados, existente em lodo de esgoto, sobre o número de bactérias. Diferentemente do que foi observado esses autores, Fließbach et al. (1994) verificaram que a toxicidade exercida por metais pesados presentes em lodo de esgoto pode suprimir a parte sensível da comunidade microbiana do solo e, desta maneira, alterar a sua composição. Hiroki (1992) avaliando a adição de metais pesados ao solo constatou que, com o aumento na dose de metais pesados, diminuiu a contribuição das bactérias no $\mathrm{CO}_{2}$ formado.

Hattori (1992), citando Doelman ${ }^{1}$ (1984), afirmou que os eucariotos são, em geral, mais resistentes a metais pesados do que os procariotos e que, portanto, haveria efeito tóxico dos metais pesados sobre as bactérias do solo, o que não foi observado neste trabalho.

A adição do lodo de curtume, além de aumentar a disponibilidade de matéria orgânica aos microrganismos do solo, elevou sensivelmente o pH das amostras de solo estudadas (figuras 9 e 10), favorecendo o crescimento de bactérias que tendem a predominar em solos com $\mathrm{pH}$ próximos à neutralidade.

\footnotetext{
${ }^{1}$ DOELMAN, P.; HAANSTRA, L. Short-term and long-term effects of cadmium, chromium, copper, nickel, lead and zinc on soil microbial respiration in relation to abiotic factors. Plant Soil. v. 79, p. 317 327, 1984.
} 


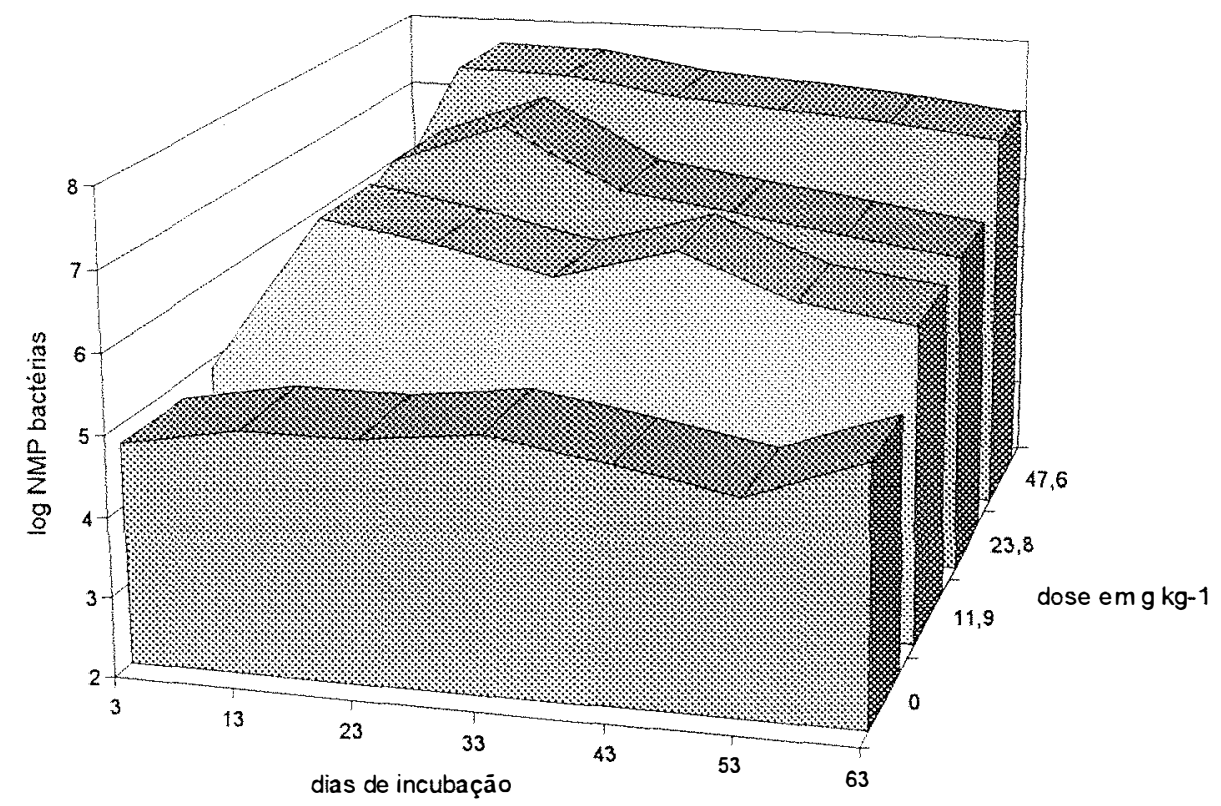

Figura 13. $\log$ NMP bactérias $\mathrm{g}^{-1}$ de solo em amostra de solo arenoso, em função da dose de lodo de curtume aplicado e do tempo de incubação.

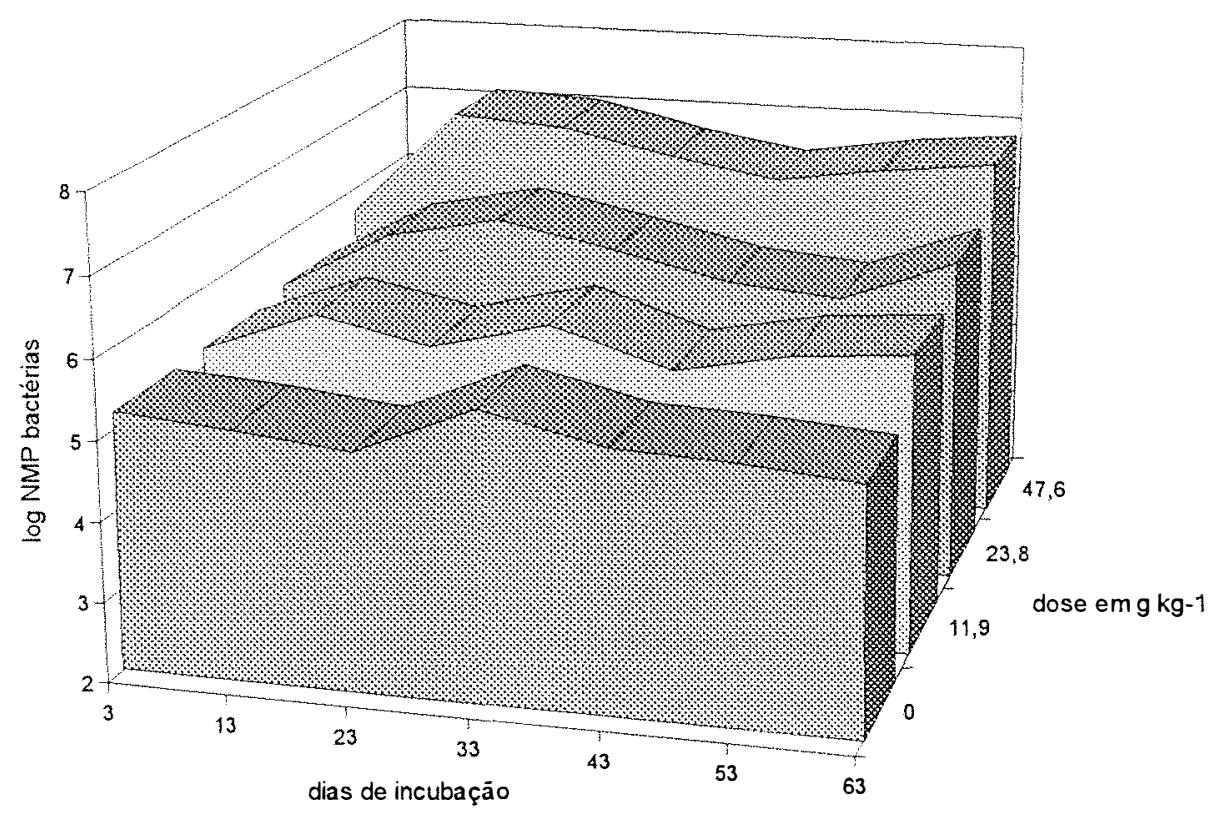

Figura 14. $\log$ NMP bactérias $\mathrm{g}^{-1}$ de solo em amostra de solo argiloso, em função da dose de lodo de curtume aplicado e do tempo de incubação. 


\subsubsection{Número mais provável de fungos}

Como pode ser visualizado nas figuras 15 e 16 , existe um aumento no número de fungos, nos dois solos estudados, com o acréscimo da dose aplicada. No entanto, nenhuma informação pode ser obtida quanto a alterações na diversidade de microrganismos existentes. Segundo alguns autores (Hattori, 1989; Hiroki, 1992; Fließbach et al. 1994) pode estar ocorrendo seleção de estirpes resistentes aos metais pesados durante o período de incubação. Outra explicação para a ausência de efeitos prejudiciais de metais pesados aos microrganismos é a presença da matéria orgânica e minerais de argila, que diminuem a toxicidade dos metais pela formação de quelatos (Lake et al., 1984; Hattori, 1989; Eivazi \& Zakaria, 1993).

O NMP de fungos nas amostras de solo estudadas foi sensivelmente afetado pela aplicação de lodo de curtume. Comparando-se os dados referentes aos periodos de incubação, não se observam diferenças estatisticamente significativas entre as doses de lodo na leitura realizada após 3 dias de incubação.

$\mathrm{Na}$ contagem de fungos, verificou-se o mesmo fato observado na contagem de bactérias, ou seja, o NMP de fungos é maior em solo arenoso em todas as parcelas, com exceção da dose zero, e é maior no solo argiloso, exatamente nas parcelas que não receberam lodo. Da mesma maneira que para bactérias, a adição do lodo favoreceu o aumento no número de fungos quantificados.

Apesar do elevado teor de crômio no lodo, não ocorreu diminuição no número de fungos. Este fato pode ser explicado pelo acréscimo no teor de matéria orgânica proporcionado pela adição de lodo e pela maior tolerância apresentada pelos fungos à presença de metais pesados (Hiroki, 1992).

A ausência de efeitos prejudiciais sobre microrganismos também foi observada por Hattori (1992), que estudou o efeito de metais pesados sobre a decomposição da matéria orgânica e sobre a microbiota do solo, observando aumento no número de fungos em amostra de solo tratado com diferentes metais pesados. 


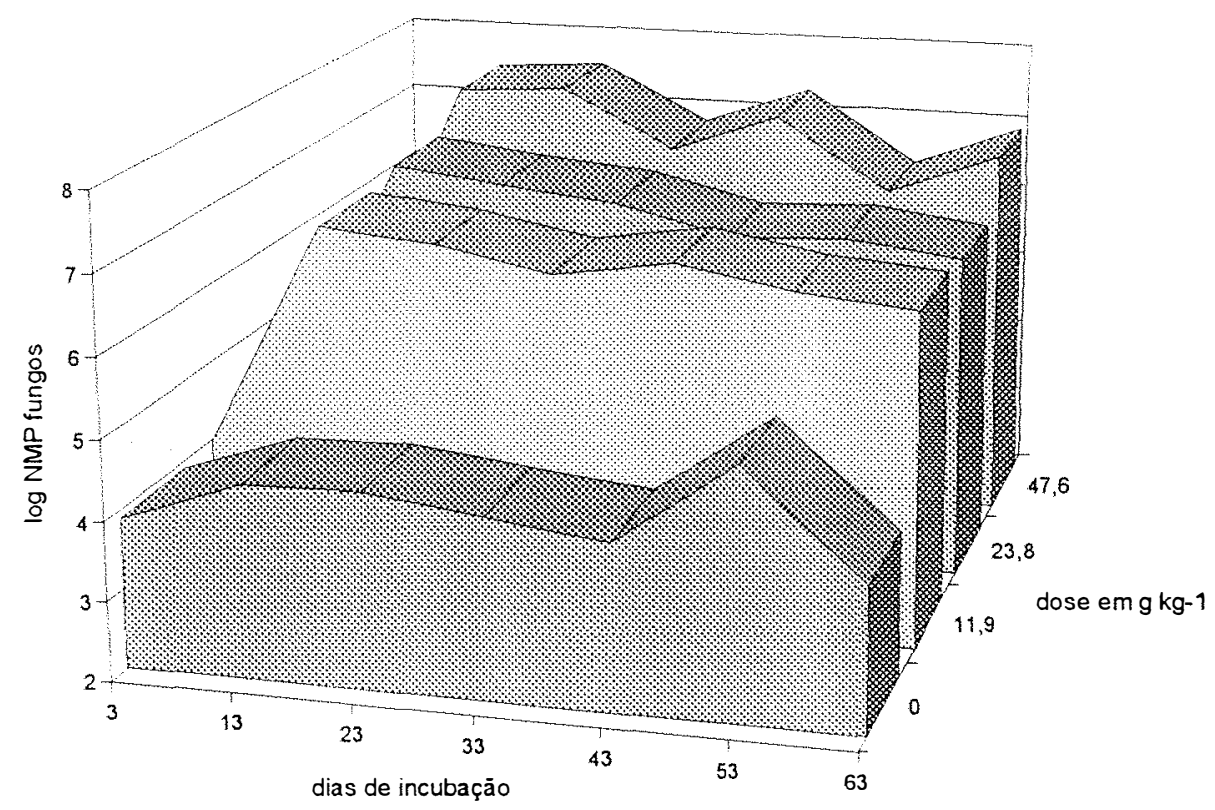

Figura 15. log NMP fungos $\mathrm{g}^{-1}$ de solo em amostra de solo arenoso, em função da dose de lodo de curtume aplicado e do tempo de incubação.

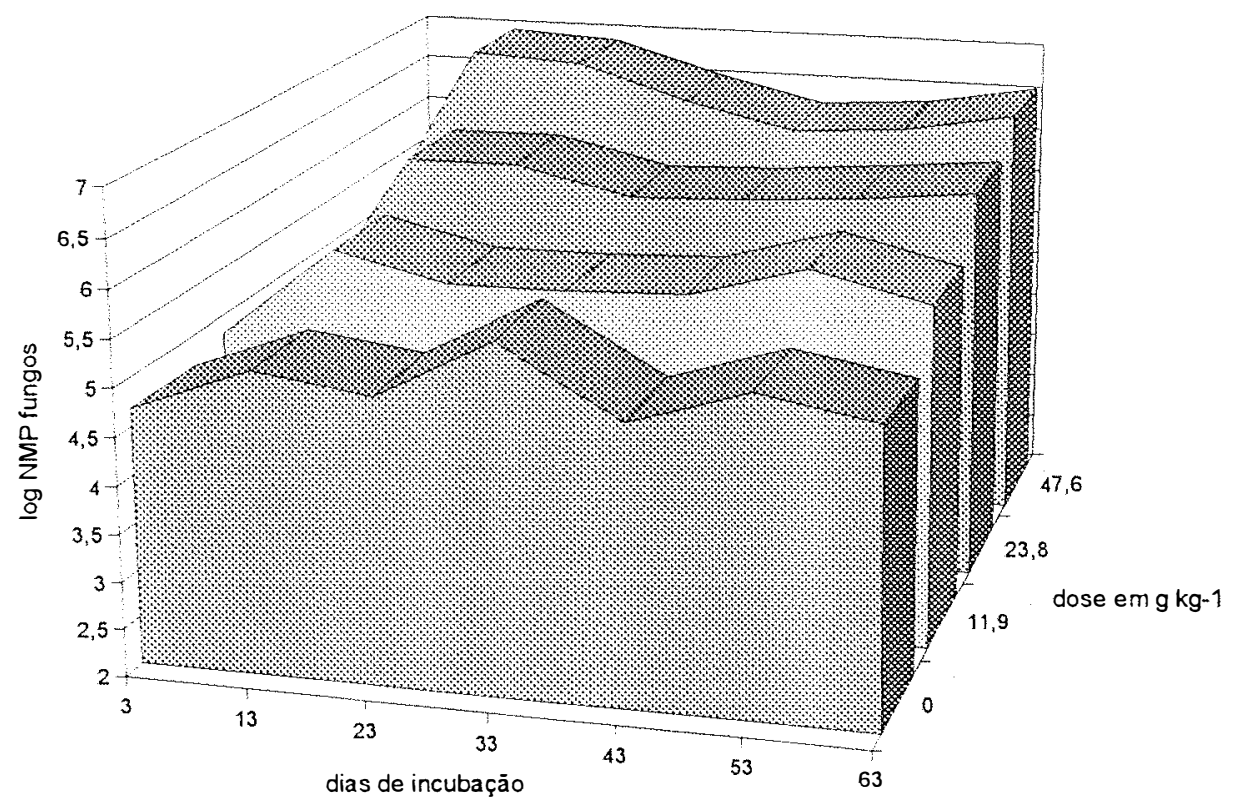

Figura 16. log NMP fungos $\mathrm{g}^{-1}$ de solo em amostra de solo argiloso, em função da dose de lodo de curtume aplicado e do tempo de incubação. 


\subsubsection{Número mais provável de microrganismos celulolíticos}

Os resultados da análise estatística mostram que ocorreu efeito significativo do período de incubação e da dose sobre o número de microrganismos celulolíticos, diferentemente do tipo de solo, cujo efeito não foi estatisticamente significativo.

A partir da análise dos dados, pode-se verificar que o NMP de microrganismos celulolíticos obtido na coleta realizada aos 3 dias de incubação é semelhante em todas as doses estudadas. Para as demais épocas de coleta não foram observadas diferenças significativas dentro da mesma dose de lodo de curtume ao longo do período de incubação, mostrando que o NMP de microrganismos celulolíticos atingiu rapidamente a fase estacionária da curva de crescimento da comunidade. Nesta fase, o número de células viáveis permanece relativamente constante por um longo período de tempo (figuras 17 e 18).

É interessante observar que o aumento no número de microrganismos celulolíticos é proporcional ao aumento da dose de lodo aplicada. Assim, observa-se que na dose de lodo de $0 \mathrm{~g} \mathrm{~kg}^{-1}$ de solo foram observados $10^{6,563}$ microrganismos por grama de solo seco, enquanto na dose de lodo de $47,6 \mathrm{~g} \mathrm{~kg}^{-1}$ de solo foram constatados $10^{8,262}$, não existindo, portanto, efeito inibitório da adição do lodo. Pode-se afirmar que a presença de matéria orgânica decomponível existente no lodo de curtume estimulou o desenvolvimento de microrganismos celulolíticos. No entanto, nada pode ser dito quanto às alterações na diversidade de microrganismos presentes na amostra de solo, uma vez que a técnica utilizada não foi qualitativa. 


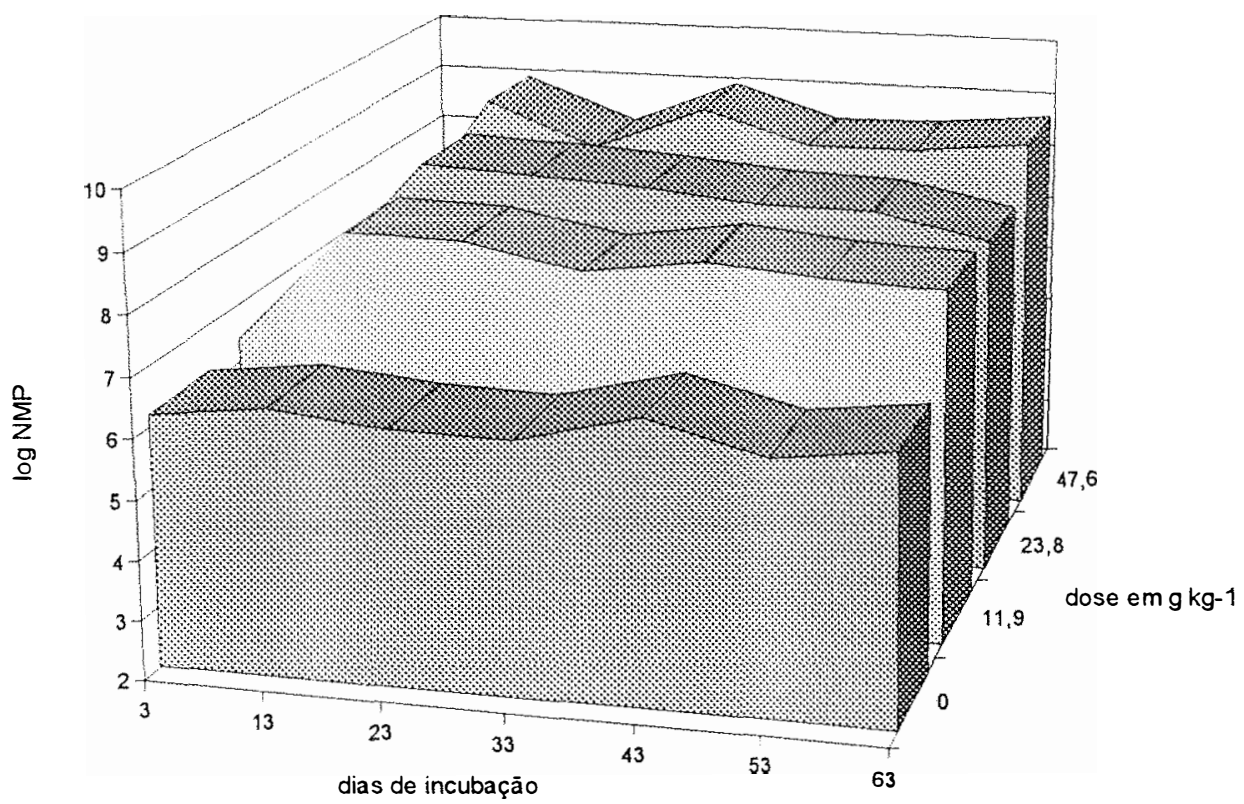

Figura 17. $\log$ NMP microrganismos celulolíticos $\mathrm{g}^{-1}$ de solo em amostra de solo arenoso, em função da dose de lodo de curtume aplicado e do tempo de incubação.

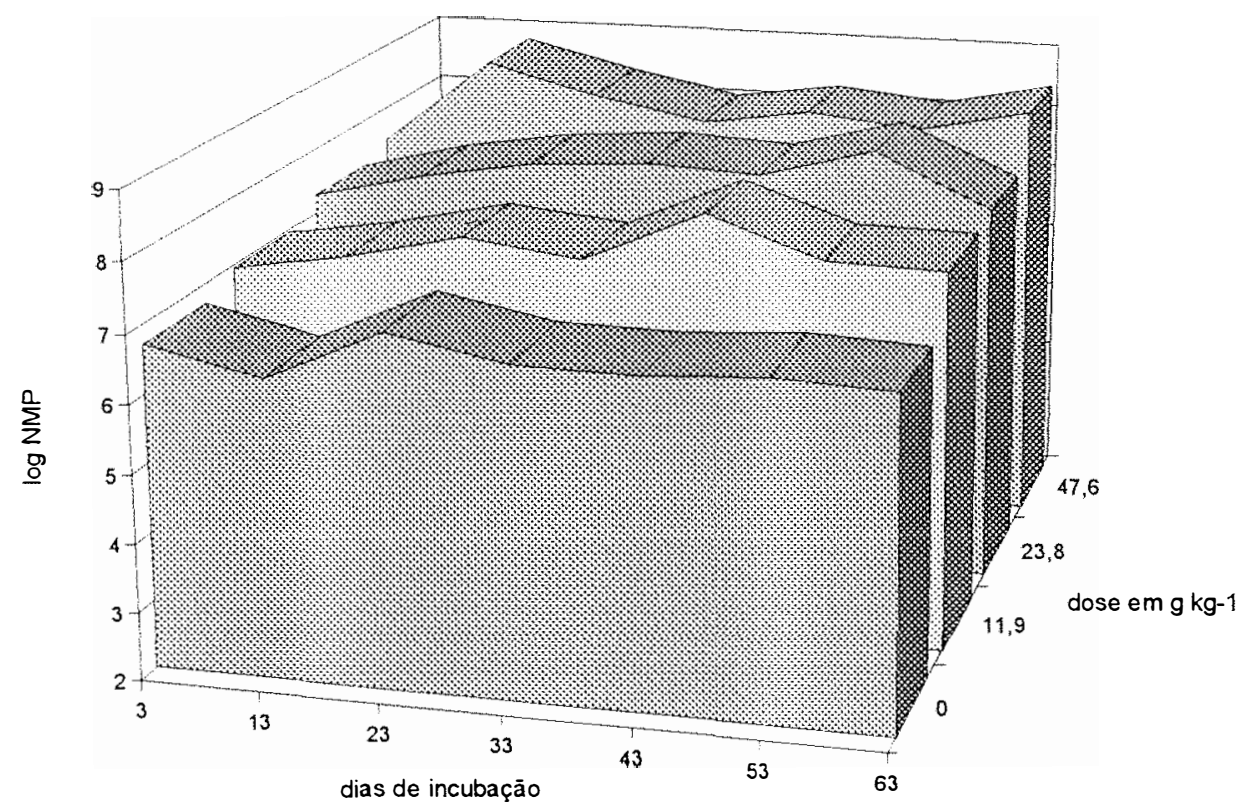

Figura 18. log NMP microrganismos celulolíticos $\mathrm{g}^{-1}$ de solo em amostra de solo argiloso, em função da dose de lodo de curtume aplicado e do tempo de incubação. 


\subsubsection{Número mais provável de microrganismos amonificantes}

Os resultados obtidos na contagem de microrganismos amonificantes estão mostrados nas figuras 19 e 20 para amostras de solo arenoso e argiloso, respectivamente. Observa-se que no solo arenoso a resposta à aplicação do lodo foi muito maior do que aquela observada no solo argiloso, provavelmente por possuir menores teores de matéria orgânica.

Observações realizadas por Smith (1991) mostram que não ocorrem efeitos prejudiciais em altas concentrações de metais pesados no solo sobre as transformações do nitrogênio. Segundo este autor, os processos de mineralização são geralmente menos sensiveis ao efeito de metais pesados do que o processo de nitrificação. Isto pode ser explicado pela grande diversidade de microrganismos capazes de mineralizar a matéria orgânica.

Da mesma maneira como foi observado por Smith (1991), a aplicação do lodo de curtume neste trabalho favoreceu a multiplicação de microrganismos amonificantes em ambas as amostras de solo (figuras 19 e 20). Com o aumento da dose aplicada, foi observado um aumento estatisticamente significativo no número de microrganismos amonificantes, sem que ocorresse aparente efeito inibitório em função da presença de compostos potencialmente tóxicos existentes no lodo. No entanto, eventuais alterações na diversidade de microrganismos amonificantes não foram avaliadas.

Rother et al. (1982) verificaram que os microrganismos responsáveis pelos processos de mineralização e nitrificação apresentaram capacidade de adaptação quando na presença de altos teores de metais pesados. Notaram, no entanto, que somente a aplicação de grandes quantidades de metais inibiu a atividade de microrganismos amonificantes, acreditando que isto se deva ao grande número de microrganismos capazes de mineralizar compostos nitrogenados. Segundo estes autores, o processo de adaptação aos metais pesados ou mesmo a seleção de estirpes mais resistentes podem ocorrer em prazos tão curtos quanto o período de incubação. 


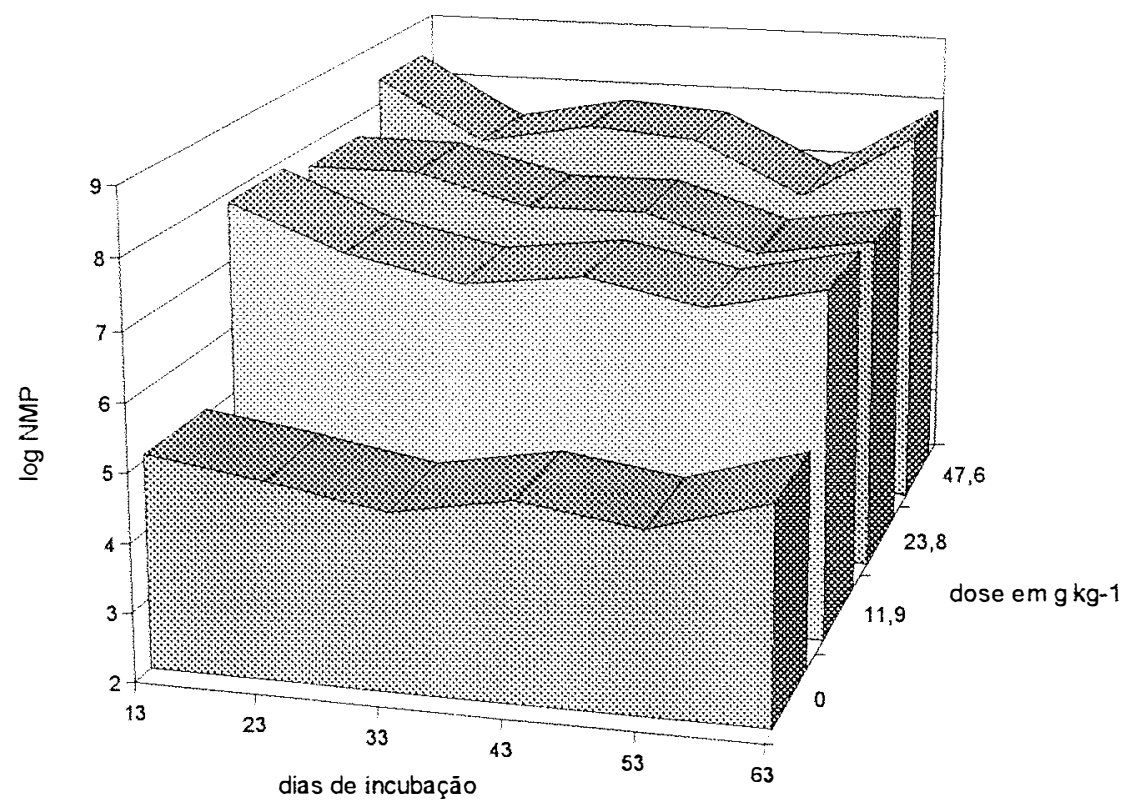

Figura 19. $\log$ NMP microrganismos amonificantes $\mathrm{g}^{-1}$ de solo em amostra de solo arenoso, em função da dose de lodo de curtume aplicado e do tempo de incubação.

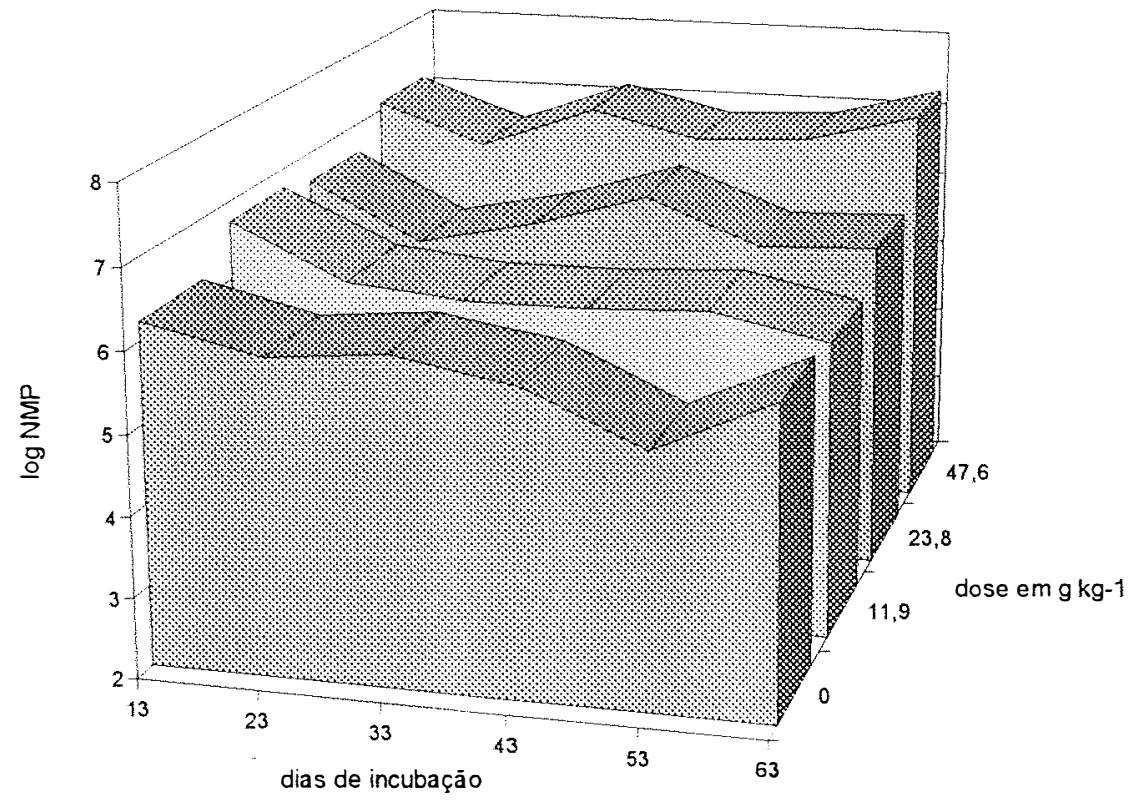

Figura 20. log NMP microrganismos amonificantes $\mathrm{g}^{-1}$ de solo em amostra de solo argiloso, em função da dose de lodo de curtume aplicado e do tempo de incubação. 


\subsubsection{Produção de $\mathrm{CO}_{2}$}

Os resultados obtidos relativos à produção de $\mathrm{CO}_{2}$ podem ser vistos nas figuras 21 e 22. Cada leitura corresponde ao somatório de 6 dias de incubação. Para que fossem atendidas as pressuposições da análise de variância, os dados foram transformados em $\left(\mathrm{mg} \mathrm{CO}_{2} \mathrm{~g} / \text { solo/6 dias) }\right)^{1 / 2}$, conforme sugestão do sistema estatístico SAS.

A um aumento na dose de lodo aplicada foi observado um acréscimo na produção de $\mathrm{CO}_{2}$, não ocorrendo em nenhuma das doses inibição do processo respiratório, mesmo na dose mais elevada de $1142,4 \mathrm{mg} \mathrm{kg}^{-1}$ de crômio ao solo. Este fato também foi observado por Benedetti et al. (1991), que avaliaram a taxa de mineralização de resíduo de curtume. No entanto, alguns autores (Chang \& Broadbent, 1981; Ueda et al., 1988b; Hattori, 1989) verificaram que a adição de sal de crômio reduzia a produção de $\mathrm{CO}_{2}$.

Segundo Leita et al. (1995), a atividade microbiana avaliada através da produção de $\mathrm{CO}_{2}$ é maior em solos contaminados como conseqüência do maior consumo de energia dos microrganismos para garantir a sobrevivência. Segundo estes autores, o estresse causado pela adição de metais pesados, tanto na forma orgânica como inorgânica, afeta o crescimento, a morfologia e o metabolismo de microrganismos do solo através de distúrbios funcionais, desnaturação de proteínas e destruição da integridade da membrana celular.

Neste trabalho, a adição de lodo rico em crômio, ao invés de diminuir, estimulou a produção de $\mathrm{CO}_{2}$, possivelmente devido à presença de matéria orgânica prontamente decomponível no lodo. Segundo Eivazi \& Zakaria (1993), este aumento da atividade enzimática pode ser atribuído ao aumento da atividade de microrganismos que são estimulados pelo alto teor de nutrientes e de matéria orgânica existente no lodo.

Observando-se os dados de contagem de microrganismos percebe-se também que a adição do lodo estimulou a multiplicação dos microrganismos, com conseqüente aumento na produção de $\mathrm{CO}_{2}$. Aqui, diferentemente do que ocorreu na contagem de microrganismos, observam-se diferenças significativas entre as doses, já na 
primeira leitura realizada após 3 dias do início do experimento, com tendência a cair ao longo do processo de incubação, possivelmente devido à redução na quantidade de compostos facilmente oxidáveis.

Interessante, no entanto, é comparar as curvas de produção de $\mathrm{CO}_{2}$ com as curvas de crescimento de microrganismos. Na primeira coleta, observa-se que, apesar de existir um número menor de microrganismos em relação às demais coletas, a produção de $\mathrm{CO}_{2}$ é proporcionalmente maior, possivelmente em função da alta atividade microbiana relacionada com a multiplicação celular.

Observando-se as figuras de 13 até 20 , juntamente com a de produção de $\mathrm{CO}_{2}$ (figuras 21 e 22), observa-se que as curvas de microrganismos são típicas curvas de crescimento, e que a de produção de $\mathrm{CO}_{2}$ mostra claramente o consumo dos compostos orgânicos existentes no solo.

A matéria orgânica presente no lodo de curtume fomeceu os compostos necessários para o desenvolvimento dos microrganismos, e as curvas de produção de $\mathrm{CO}_{2}$ simplesmente refletem o consumo de material energético adicionado, ao longo do período de incubação. O que se constata, no entanto, é que a presença de crômio no lodo proveniente do processamento de couro não afetou, pelo menos de forma visível, a oxidação da matéria orgânica. Esse fato, contudo, não significa que a utilização de lodo proveniente do processamento de couro seja inócua. A mineralização da matéria orgânica não significa o desaparecimento do crômio. Pelo contrário, a redução dos teores de matéria orgânica no solo acabam por tornar esse metal mais prontamente disponível, com conseqüente aumento na absorção por plantas e com efeitos sobre os processos microbiológicos que ocorrem no ambiente solo. 


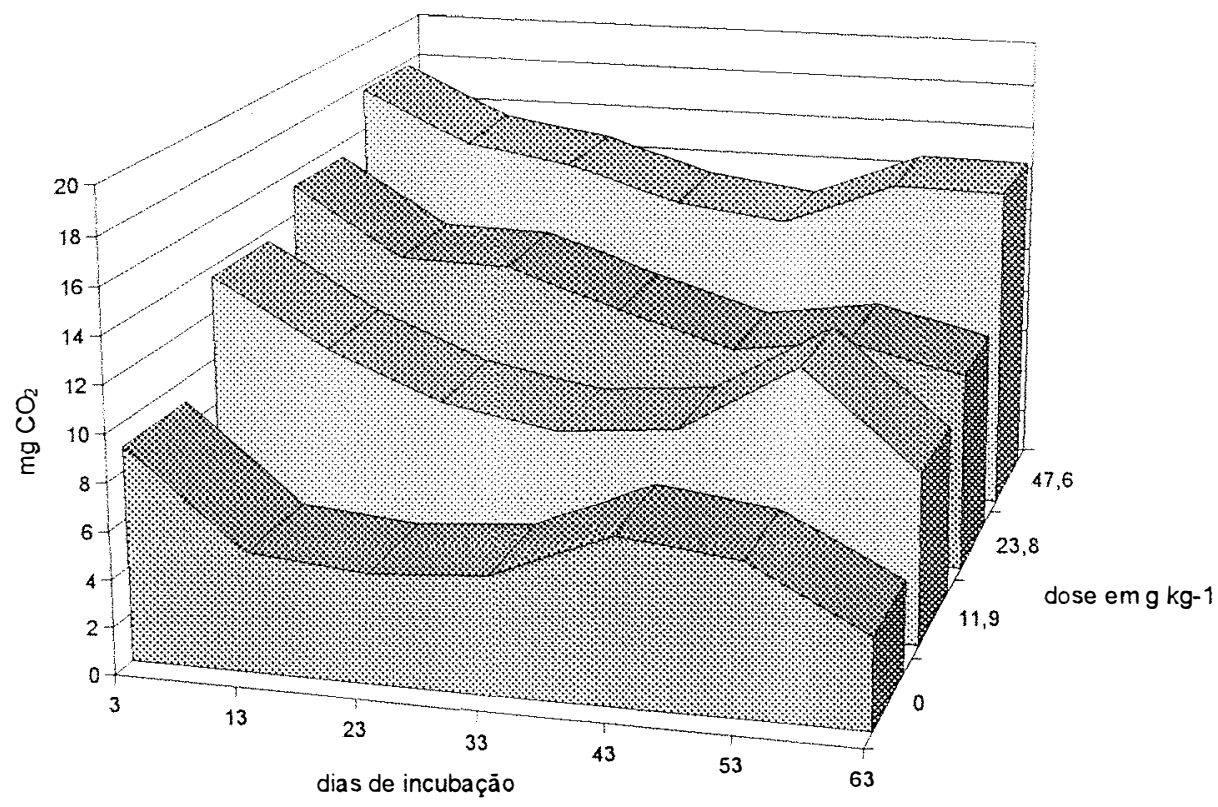

Figura 21. Produção de $\mathrm{CO}_{2}$ em amostra de $50 \mathrm{~g}$ de solo arenoso, expresso em $\mathrm{mg} \mathrm{CO}_{2} / 6$ dias, em função da dose de lodo de curtume aplicado e do tempo de incubação.

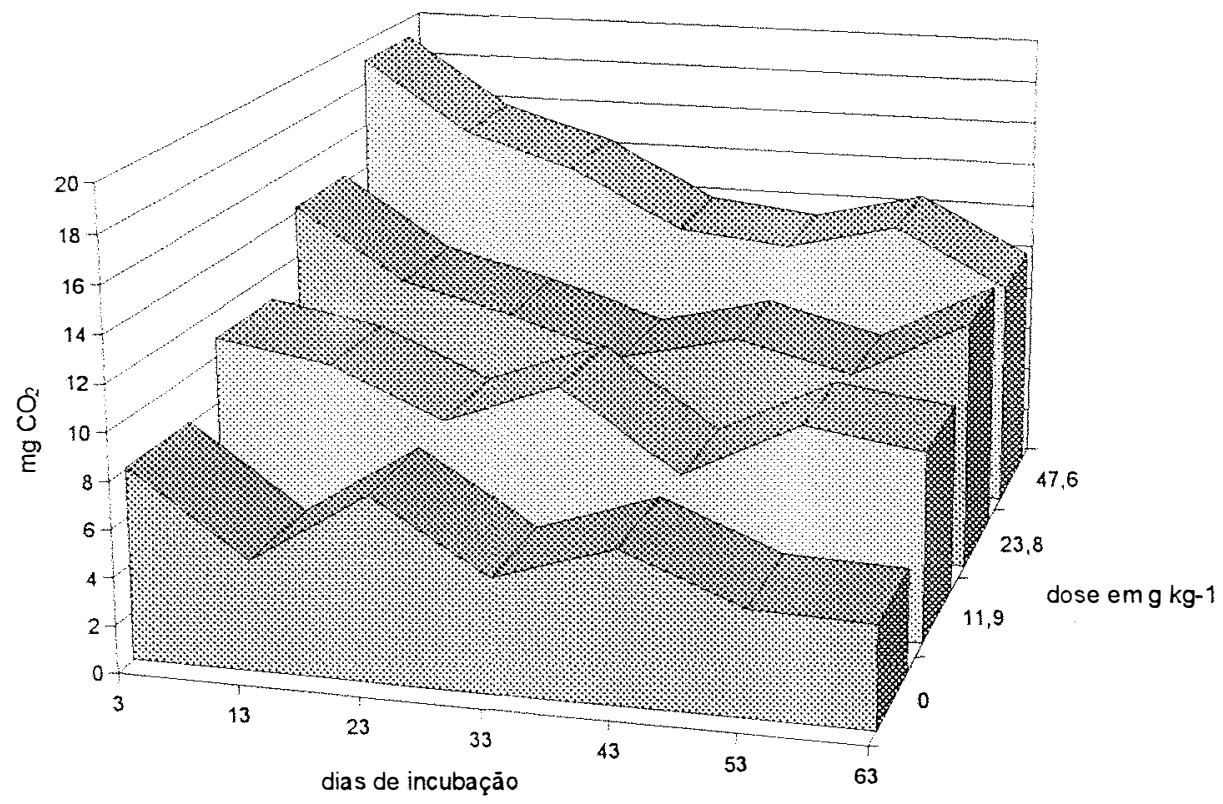

Figura 22. Produção de $\mathrm{CO}_{2}$ em amostra de $50 \mathrm{~g}$ de solo argiloso, expresso em $\mathrm{mg} \mathrm{CO}_{2} / 6$ dias, em função da dose de lodo de curtume aplicado e do tempo de incubação. 


\subsubsection{Biomassa microbiana}

Os valores de biomassa microbiana obtidos nas primeiras semanas de incubação, apresentavam variância extremamente elevada e, para que fossem atendidos os requisitos da análise de variância, foram desconsiderados.

A determinação da biomassa microbiana nas primeiras semanas de incubação foi prejudicada, pois a matéria orgânica recentemente adicionada se encontrava em processo de decomposição, conforme pode ser observado nas figuras de produção de $\mathrm{CO}_{2}$. Segundo Ocio \& Brookes (1990) o método de fumigação e incubação, proposto por Jenkinson \& Powlson (1976), não é aplicável quando a matéria orgânica adicionada se encontra em ativo processo de decomposição. Segundo estes autores, os demais métodos de quantificação de biomassa microbiana disponíveis ainda não foram rigorosamente testados nestas condições.

Os dados da tabela 5 mostram que os teores de biomassa microbiana aumentaram linearmente à adição de lodo, ou seja, até a dose estudada não ocorreu efeito inibitório, diferentemente do observado por Brookes \& McGrath (1984), que verificaram redução na biomassa microbiana do solo, sugerindo um efeito tóxico devido à presença de metais pesados. No entanto, estes resultados são semelhantes aos obtidos por Fließbach et al. (1994), que verificaram que a aplicação de lodo de esgoto com baixos teores de metais pesados favoreceu a produção de biomassa, bem como a atividade dos microrganismos do solo.

Verifica-se, através da tabela 6, que houve efeito do fator tempo de incubação sobre a quantidade de biomassa microbiana presente, ou seja, a quantidade de biomassa microbiana diminuiu ao longo do período estudado. Isto pode ser atribuído ao consumo da matéria orgânica, diminuindo a disponibilidade de carbono disponível para os microrganismos.

A avaliação conjunta de produção de $\mathrm{CO}_{2}$ e quantidade de biomassa microbiana permite dizer que não houve efeito inibitório dos compostos potencialmente tóxicos existentes no lodo de curtume sobre os microrganismos das amostras de solo estudadas. 
No entanto, estes resultados não permitem preconizar a utilização irrestrita de lodo de curtume no solo, pois as técnicas empregadas não conseguem avaliar mudanças qualitativas nas comunidade microbianas do solo. Como já foi dito, pode estar ocorrendo seleção de estirpes ou mesmo de espécies resistentes à presença de compostos potencialmente tóxicos e que, possivelmente possui comportamento distinto daquele da comunidade original do solo. O uso de técnicas de biologia molecular poderia auxiliar na identificação de alterações na composição genética da microbiota do solo.

Tabela 5. Quantidade de biomassa microbiana em função da dose de lodo aplicada.

\begin{tabular}{ll}
\hline Dose em $\mathrm{g} \mathrm{kg}^{-1}$ & Biomassa microbiana do solo $\mu \mathrm{g} \mathrm{C} / \mathrm{g} \mathrm{solo}^{-1}$ \\
\hline 0 & $44,15 \mathrm{a}$ \\
11,9 & $38,92 \mathrm{a}$ \\
23,8 & $58,10 \mathrm{~b}$ \\
47,6 & $71,14 \mathrm{~b}$ \\
\hline
\end{tabular}

Médias seguidas de letras iguais não diferem entre si ao nível de 0,05 de probabilidade pelo teste de Student.

Tabela 6. Quantidade de biomassa microbiana em função do tempo de incubação.

\begin{tabular}{ll}
\hline Dias de incubação & Biomassa microbiana do solo $\mu \mathrm{g} \mathrm{C} / \mathrm{g} \mathrm{solo}^{-1}$ \\
\hline 23 & $86,27 \mathrm{a}$ \\
33 & $35,62 \mathrm{bd}$ \\
43 & $63,33 \mathrm{c}$ \\
53 & $42,98 \mathrm{~d}$ \\
63 & $44,68 \mathrm{~d}$ \\
\hline
\end{tabular}

Médias seguidas de letras iguais não diferem entre si ao nível de 0,05 de probabilidade pelo teste de Student. 


\subsubsection{Degradação de celulose}

Para a realização da análise estatística desta variável, as perdas percentuais de celulose foram transformadas em $\log \mathrm{x}$, conforme sugestão do programa estatístico SAS, para que fossem atendidas as condições da análise de variância.

Não ocorreu diferença estatisticamente significativa para os solos estudados para a variável degradação da celulose. O mesmo ocorreu com o NMP de microrganismos celulolíticos, ou seja, não houve diferenças entre os solos também.

Também aqui não se observou efeito inibitório da dose de lodo de esgoto adicionada não existindo diferenças entre as doses aplicadas para solo arenoso (figura23).

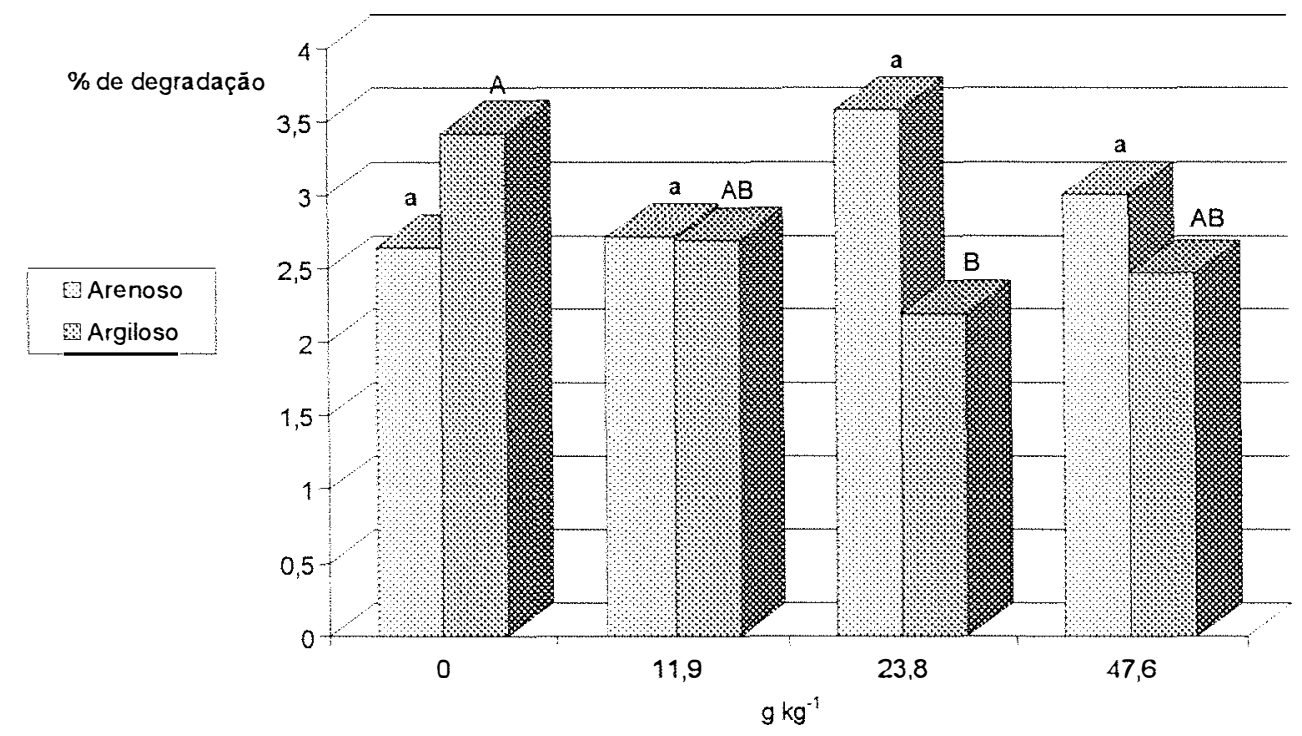

Médias seguidas de letras iguais não diferem entre si, ao nível de 0,05 de probabilidade pelo teste $t$ de Student. Letras minúsculas correspondem à amostra de solo arenoso e maiúscula à amostra de solo argiloso

Figura 23. Perda de celulose de papel de filtro, em amostras de dois solos tratadas com doses de lodo de curtume e incubadas por 4 semanas. 
Os métodos de avaliação da atividade e do número de microrganismos em amostras de solo utilizados neste trabalho não são capazes de determinar alterações na variabilidade de microrganismos da amostra. A verificação do surgimento de estirpes resistentes através de utilização de meio de cultura enriquecido específico ou de técnicas moleculares poderia fornecer indicadores mais precisos da alteração que estas substâncias proporcionam aos microrganismos do solo.

A ausência de efeito não é garantia de que o uso de lodo industrial seja inócuo aos microrganismos do solo. Efeitos de longo prazo da aplicação de compostos tóxicos poderiam resultar no desenvolvimento de uma comunidade microbiana menos eficiente e mais resistente a estes compostos.

O potencial poluidor associado com a aplicação ao solo de lodo de esgoto, tal como a lixiviação de nitrato, adição e acumulação de metais pesados e inibição do crescimento de plantas, permanece como problema ecológico sério e merece ser melhor estudado. 


\section{CONCLUSÕES}

1. A metodologia de quantificação de bactérias e de fungos em amostras de solo por plaqueamento de gotas proporcionou a obtenção de resultados semelhantes àqueles obtidos pelo procedimento tradicional, com a vantagem de economia de reagentes e trabalho. A metodologia mostrou-se sensível a alterações na amostra resultantes da adição de matéria orgânica e sal de crômio.

2. A quantificação de $\mathrm{CO}_{2}$ pelo procedimento FIA forneceu resultados mais precisos e em menor período de incubação das amostras.

3. A aplicação, às amostras de solo, de lodo proveniente da indústria de processamento de couro, rico em crômio, não impediu o crescimento e a atividade de microrganismos, pelo contrário, favoreceu a sua multiplicação e atividade.

4. A aplicação de lodo de curtume provocou enorme aumento na condutividade elétrica do solo. 


\section{REFERÊNCIAS BIBLIOGRÁFICAS}

ALlOWAY, B.J. Heavy Metals in soils 1.ed. Nova York: Halsted Press, 1990. 339p.

AMARAL SOBRINHO, N.M.B.; COSTA, L.M.; DIAS, L.E.; BARROS, N.F. Aplicação de resíduo siderúrgico em um latossolo: Efeitos na correção do solo e na disponibilidade de nutrientes e metais pesados. Revista Brasileira de Ciência do Solo, v. 17, p. 299-304, 1993.

ANDRADE, D.S.; HAMAKAWA, P.J. Estimativa do número de células viáveis de rizóbio no solo e em inoculantes por infecção em plantas. In: Hungria, M.; Araujo, R. Manual de métodos empregados em estudos de microbiologia agrícola. l.ed. Brasília: Embrapa-SPI, 1994. cap. 3, p. 63-94.

ANDRADE, D.S.; MIYAZAWA, M.; HAMAKAWA, P.J. Microrganismos amonificadores e nitrificadores. In: Hungria, M.; Araujo, R., Manual de métodos empregados em estudos de microbiologia agrícola. 1.ed. Brasília: Embrapa-SPI, 1994. cap. 17 , p. 355-367.

ASSOCIAÇÃO BRASILEIRA DE NORMAS TÉCNICAS (ABNT). NBR 10004 Resíduos Sólidos. Forum Nacional de Normalização, 1987. 63p.

BARDGETT, R.D.; SPEIR T.W.; ROSS D.J.; YEATES G.W.; KETTLES H.A. Impact of pasture contamination by copper, chromium and arsenic timber preservatives on soil microbial properties and nematodes [in New Zealand]. Biology and Fertility of Soils, v. 18, n.1, p. 71-79, 1994. 
BARTLETT, R.J.; KIMBLE, J.M. Behavior of Chromium in Soils: I. Trivalent forms. Journal of Environmental Quality, v. 5, n. 4, p. 379-383, 1976 a.

BARTLETT, R.J.; KIMBLE, J.M. Behavior of Chromium in Soils: II. Hexavalent forms. Journal of Environmental Quality, v. 5, n. 4, p. 383-386, 1976 b.

BECK, T. Untersuchungen über die toxische Wirkung der in Siedlungsabfällen häufigen Schwermetalle auf die Bodenmikroflora. Zeitschrift für Pflanzen-ernährung und Bodenkunde, v. 144, p. 613-627, 1981.

BENEDETTI, A.; CECCANTI, B.; CALCINAI, M.; TARSITANO, R. Decomposition of chromium-containing leather residues in a sandy soil, Suelo y Planta, v. 1, n. 1, p. $15-24,1991$.

BOLLAG, J.M.; BARABASZ, W. Effect of heavy metals on the denitrification process in soil. Journal of Environmental Quality, v. 8, n.2, p. 196-201, 1979.

BRANDÃO, E. M.; Os componentes da comunidade microbiana do solo. In: CARDoso, J. B. N.; TSAI, S. M.; NEVES, M. C. P. Microbiologia do Solo. Campinas: Sociedade Brasileira de Ciência do Solo, 1992. cap. 1, p. 1-15.

BRASIL. Ministério da Agricultura. Laboratório Nacional de Referência Vegetal. Análise de Corretivos, Fertilizantes e Inoculantes: Métodos Oficiais, 1983.

BRENDECKE, J.W.; AXELSON, R.D.; PEPPER, I.L. Soil microbial activity as an indicator of soil fertility: long-term effects of municipal sewage sludge on an arid soil. Soil Biology and Biochemistry, v. 25, n.6, p. 751-758, 1993.

BROOKES, P.C. The use of microbial parameters in monitoring soil pollution by heavy metals. Biology and Fertility of Soils, v. 19, n.4, p. 269-279, 1995.

BROOKES, P.C.; HEIJNEN, C.E.; MCGRATH, S.P.; VANCE, E.D. Soil microbial biomass estimates in soils contaminated with metals. Soil Biology and Biochemistry, v. 18, n.4, p. 383-388, 1986. 
BROOKES, P.C.; MCGRATH, S.P. Effects of metal toxicity on the size of the soil microbial biomass. Journal of Soil Science, v. 35, p. 341-346, 1984.

BROWN, G.; BRINKMANN, K. Heavy metal tolerance in Festuca ovina L. from contaminated sites in the Eifel Mountains, Germany. Plant and Soil, v. 143, p. 239$247,1992$.

BRUEMMER, G.W.; GERTH, J.; TILLER, K.G. Reaction kinetics of the adsorption and desorption of nickel, zinc and cadmium by goethite. I. Adsorption and difusion of metals. Journal of Soil Science, v. 39, p. 37-52, 1988.

BRÜNE, H. Bodenschutz und moderne Landwirtschaft, Kassel-Harleshausen: Auswertungs-und Informationsdienst für Emährung, Landwirtschaft und Forsten (AID) 1987. 32p.

BURKHARDT, C.; INSAM, H.; HUTCHINSON, T.C.; REBER, H.H. Impact of heavy metals on the degradative capabilities of soil bacterial communities. Biology and Fertility of Soils, v. 16, p. 154-156, 1993.

BURNETT, G.W.; PELCZAR JUNIOR, M.J.; CONN, H.J. Preparation of media. In: Society of American Bacteriologists Manual of Microbiological Methods. New York, Toronto, London: McGraw-Hill Book Company, 1957. 315p.

CASTILHOS, D.D.;VIDOR, C.; TEDESCO, M.J. Alterações químicas do solo pela adição de resíduos de curtume e de cromo hexavalente. In: Congresso Brasileiro de Ciência do Solo, 26., Rio de Janeiro, 1997. SBCS, 1997.

CHANDER, K.; BROOKES, P.C. Is the dehydrogenase assay invalid as a method to estimate microbial activity in copper-contaminated soils? Soil Biology and Biochemistry, v. 23, n. 10, p. 909-915, 1991. 
CHANDER, K.; BROOKES, P.C.; HARDING, S.A. Microbial biomass dynamics following addition of metal-enriched sewage sludges to a sandy loam. Soil Biology and Biochemistry, v. 27, n.11, p. 1409-1421, 1995.

CHANG, A.C.; PAGE, A.L.; WARNEKE, J.E.; GRGUREVIC, E. Sequential extraction of soil heavy metals following a sludge application. Journal of Environmental Quality, v. 13, n.1, p. 33-38, 1984.

CHANG, F.H.; BROADBENT, F.E. Influence of trace metals on carbon dioxide evolution from a yolo soil. Soil Science, v. 132, p. 416-421, 1981.

CRUCIANI, D.E. A drenagem na agricultura. 2.ed. São Paulo: Nobel, 1983. 337p.

DOELMAN, P.; HAANSTRA, L. Effects of lead on the soil bacterial microflora. Soil Biology and Biochemistry, v. 11, p. 487-491, 1979.

EIVAZI, F.; ZAKARIA, A. Beta-Glucosidase activity in soil amended with sewage sludge. Agriculture, Ecosystems and Environment, v. 43, n.2, p. 155-161, 1993.

EL-SHINNAWI, M.M.; EL-SHIMI, S.A.; BADAWI, M.A. Enzyme activities in manured soils. Biological Wastes, v. 24, p. 283-295, 1988.

ELTROP, L.; BROWN, G.; JOACHIM, O.; BRINKMANN, K. Lead tolerance of Betula and Salix in the mining area of Mechernich/Germany. Plant and Soil, v. 131, p. 275-285, 1991.

FLIEßBACH, A.; MARTENS, R.; REBER, H.H. Soil microbial biomass and microbial activity in soils treated with heavy metal contaminated sewage sludge. Soil Biology and Biochemistry, v. 26, n.9, p. 1201-1205, 1994.

HATTORI, H. Influence of cadmium on decomposition of sewage sludge and microbial activities in soils. Soil Science and Plant Nutrition, v. 35 n.2, p. 289-299, 1989. 
HATTORI, H. Influence of heavy metals on soil microbial activities. Soil Science and Plant Nutrition, v. 38, n. 1, p. 93-100, 1992.

HECKMAN, J.R.; ANGLE, J.S.; CHANEY, R.L. Residual effects of sewage sludge on soybean: I. Acummulation of heavy metals. Journal of Environmental Quality, v. 16, n. 2, p. 113-11 7, 1987.

HIROKI, M. Effects of heavy metal contamination on soil microbial population. Soil Science and Plant Nutrition, v. 38 n. 1, p. 141-147, 1992.

HOLMES, B. Life Unlimited. New Scientist, v. 149, n. 2016, p. 26-29, 1996.

HUNGRIA, M; ARAUJO, R. Manual de métodos empregados em estudos de microbiologia agrícola. Brasília: Embrapa, 1994. 542p.

INSTITUT FÜR BODENKUNDE DER UNIVERSITÄT BONN. Script zum Praktikum zur Bodenmikrobiologie. Bonn: IBUB, julho, 1992. 26p.

JARDIM, W.F.; PASQUINI, C.; GUIMARÃES, J.R.; FARIA, L.C. Short-term toxicity test using Escherichia coli: Monitoring $\mathrm{CO}_{2}$ production by flow injection analysis. Water Resource, v. 24, n.3, p. 351-354, 1990.

JENKINSON, D. S.; POWLSON, L. The effect of biocidal treatments on metabolism in soil -V: A method for measuring soil biomass. Soil Biology and Biochemistry, v. 8, p. 209-213, 1976.

KABATA-PENDIAS, A.; PENDIAS, H. Trace elements in soils and plants. Boca Raton: CRC Press, Inc., 1986. 315p.

KORCAK, R.F.; GOUIN, F.R.; FANNING, D.S. Metal content of plants in a tree nursery treated with composted sludge. Journal of Environmental Quality, v. 8, n.1, p. 63-69, 1979.

KRETZSCHMAR, R. Klärschlammausbringung. In: BLUME H.-P. Handbuch des Bodenschutzes. Landsberg: Ecomed Verlagsgesellschaft, 1992. cap. 1.4, p.58-71. 
LAKE, D.L.; KIRK, P.W.W.; LESTER, J.N. Fractionation, characterization and speciation of heavy metals in sewage sludge and sludge-amended soils: A Review. Journal of Environmental Quality, v. 13, n.2, p. 175-183, 1984.

LEITA, L.; NOBILI, M. DE; MUHLBACHOVA, G.; MONDINI, C.; MARCHIOL, L.; ZERBI, G. Bioavailability and effects of heavy metals on soil microbial biomass during laboratory incubation. Biology and Fertility of Soils, v. 19, n.2-3, p. 103108, 1995.

LESCHBER, R.; DAVIS, R.D.; L'HERMITE, P. Chemical Methods for Assessing Bio-Available Metals in Sludges and Soils. Elsevier Applied Science Publishers, 1984.

LINDEMANN, W.C.; LINDSEY, D.L.; FRESQUEZ, P.R. Amendment of mine spoil to increase the number and activity of microorganisms. Soil Science Society American Journal, v. 48, p. 574-578, 1984.

LOPES, E.S.; PERON, S.C.; PORTUGAL, E.P.; CAMARGO, O.A.; FREITAS, S.S. Atividade respiratória de solo tratado com vinhaça e herbicida. Bragantia. v. 45, n. 1, p. 205-210, 1986.

LORENZ, S.E.; MCGRATH, S.P.; GILLER, K.E. Assessment of free-living nitrogen fixation activity as a biological indicator of heavy metal toxicity in soil. Soil Biology and Biochemistry, v. 24, n.6, p. 601-606, 1992.

LYNCH, J.M. Biotecnologia do Solo: Fatores microbiológicos na produtividade agrícola. São Paulo: Ed. Manole, 1986. 209p.

MALISZEWSKA, W.; DEC, S.; WIERZBICKU, H.; WOZNIAKOWSKU, A. The influence of various heavy metal compounds on the development and activity of soil microorganisms. Environmental Pollution, v. 37, n. 195-215, 1985. 
MARTIN, J.P. Use of acid, rose bengal and streptomycin in the plate method for estimating soil fungy. Soil Science, n. 134, p. 1528-1529, 1950.

MIYAZAWA, M.; ANDRADE, D. S.; MORAES, S. R. Determinação do $\mathrm{CO}_{2}$ do solo por condutivimetria em sistema de injeção em fluxo (compact disc). In: CONGRESSO LATINO AMERICANO DE CIÊNCIA DO SOLO, 13., Águas de Lindóia, 1996. Solo-suelo 96: trabalhos. Piracicaba: SBCS/SLCS, 1996.

MUNIER-LAMY, C.; ADRIAN, PH.; BERTHELIN, J. Fate of organo-heavy metal complexes of sludges from domestic wastes in soils: A simplified modelization. Toxicological and Environmental Chemistry, v. 31-32, p. 527-538, 1991.

OCIO, J.A.; BROOKES, P.C. An evaluation of methods for measuring the microbial biomass in soils following recent additions of wheat straw and the caracterization of the biomass that develops. Soil Biology and Biochemistry, v. 22, p. 685-694, 1990.

ÖHLINGER, R. Bestimmung der Bodenatmung im Laborversuch. In: SCHINNER, F.; ÖHLINGER, R.; KANDELER, E.; MARGESIN, R. Bodenbiologische Arbeitsmethoden. Berlin, Springer-Verlag, 1993, p. 86-90.

OLSON, B.H.; THORNTON, I. The resistance pattems to metals of bacterial populations in contaminated land. Journal of Soil Science, v. 33, p. 27 1-277, 1982.

PEPPER, I.L.; BRENDECKE, J.W.; AXELSON, R.D. Metal contamination on soil microorganisms. Soil Biology and Biochemistry, v. 26, n.8, p. 1099, 1994.

PROKISCH, J.; KOVÁCS, B.; GYÕRI, Z.; LOCH, J. A simple and inexpensive method for chromium speciation in soil extracts. Commun. Soil Sci. Plan. Anal., v. 26, n. 13-14, p. 2051-2065, 1995.

RAIJ,B.; QUAGgIO, J.A.; CANTARELlA, H. FERREIRA, M. E.; LOPES, A.S.; BATAGLIA, O.C. Análise química do solo para fins de fertilidade. Campinas: Fundação Cargill, 1987. 170 p. 
REBER, H.; FLIEßBACH, A. Auswirkungen einer langjährigen Zufuhr von Klärschlamm auf Bodenmikroorganismen und ihre Leistungen. In: SAUERBECK, D.; LÜBBEN, S. Auswirkung von Siedlungsabfällen auf Böden, Bodenorganismen und Pflanzen. Jülich: Forschungszentrum Jülich GmbH, 1991. cap. 9 , p. 327-358.

REIS, B. F. Análise química por injeção em fluxo: vinte anos de desenvolvimento. Química Nova, v. 19, n. 1, p. 51-58, 1996.

REIS, B. F.; GINÉ, M. F.; KRONKA, A. M. A análise química por injeção em fluxo contínuo. Química Nova, v. 12, n. 1, p. 82-91, 1989.

ROSS, D.S.; SJOGREN, R.E.; BARTLETT, R.J. Behavior of Chromium in Soils: IV. Toxicity to Microorganisms. Journal of Environmental Quality. v. 10 n. 02 p. 145-148, 1981.

ROTHER, J.A.; MILLBANK, J.W.; THORNTON, I. Effects of heavy-metal additions on ammonification and nitrification in soils contaminated with cadmium, lead and zinc. Plant and Soil, v. 69, p. 239-258, 1982.

SCHEFFER, F.; SCHACHTSCHABEL, P. Lehrbuch der Bodenkunde. Stuttgart: Verlag Enke, 1992. 491p.

SCHIMMING, C. -G. Belastung mit Metallen In: BLUME, H.-P. Handbuch des Bodenschutzes. Landsberg: Ecomed Verlagsgesellschaft, 1992. cap. 1.4, p.58-71.

SCHINNER, F.; ÖHLINGER, R.; KANDELER, E. MARGESIN, R. Bodenbiologische Arbeitsmethoden. 2.ed. Berlin: Springer-Verlag, 1993. 389p.

SIQUEIRA, J. O.; FRANCO, A. A. Biotecnologia do Solo. Brasília: MEC Ministério da Educação, ABEAS; Lavras: ESAL, FAEPE, 1988. 236p.

SISTROM, W.R. A vida dos micróbios. Trad. de K. G. Hell. São Paulo: Pioneira, 1973. 149p. 
SMITH, S.R. Effects of sewage sludge application on soil microbial processes and soil fertility. Advances in Soil Science, v. 16, p. 191-212, 1991.

SMITH, S.R.; HADLEY, P. Nitrogen fertilizer value of activated sewage derived protein: effect of environment and nitrification inhibitor on $\mathrm{NO}_{3}$ - release, soil microbial activity and yield of summer cabbage. Fertilizer Research, v. 33, n.1, p. 47-57, 1992.

SPOSITO, G.; LUND, L. J.; CHANG, A.C. Trace Metal Chemistry in Arid-Zone Field Soil Amended with Sewage Sludge: I. Fractionation of $\mathrm{Ni}, \mathrm{Cu}, \mathrm{Zn}, \mathrm{Cd}$, and $\mathrm{Pb}$ in Solid Phases. Soil Science American Journal, v. 46, p. 260-270, 1982.

SUTTON, S.D.; BARRETT, G.W.; TAYLOR, D.H. Microbial metabolic activities in soils of old-field communities following eleven years of nutrient enrichment. Environmental Pollution, v. 73, n.1, p. 1-10, 1991.

TEDESCO, J.M.; GIANELLO, C. Descarte em solos de resíduos de curtume. In: Congresso Brasileiro de Ciência do Solo, 26., Rio de Janeiro, 1997. SBCS, 1997.

TRAUTZ, D.; Böden als Lebensraum von Organismen. In: BLUME H.-P. Handbuch des Bodenschutzes. Landsberg: Ecomed Verlagsgesellschaft, 1992. cap. 1.4, p.5871.

TSAI, S.M.; BARAIBAR, A.V.L.; ROMANI, V.L.M. Efeito de fatores do solo. In: CARDOSO, E.J.B.N., TSAI, S.M.; NEVES, M.C.P., ed. Microbiologia do solo. Campinas: Sociedade Brasileira de Ciência do Solo, 1992. cap. 5, p. 59-72.

UEDA, K.; KOBAYASHI, M.; TAKAHASHI, E. Effect of anionic heavy metals on ammonification and nitrification in soil. Soil Science and Plant Nutrition, v. 34, n.1, p. 139-146, 1988a. 
UEDA, K.; KOBAYASHI, M.; TAKAHASHI, E. Effect of chromate and organic amendments on the composition and activity of the microorganism flora in soil. Soil Science and Plant Nutrition, v. 34, n.2, p. 233-240, 1988 b.

VALSECCHI, G.; GIGLIOTI, C.; FARINI, A. Microbial biomass, activity, and organic matter accumulation in soils contaminated with heavy metals. Biology and Fertility of Soils, v. 20, p. 253-259, 1995.

VANCE, E.D.; BROOKES, P.C.; JENKINSON, D.S. An extraction method for measurement soil microbial biomass C. Soil Biology and Biochemistry, v. 19, p. 703-707, 1987.

WITTER, E.; GLLER, K.E.; MCGRATH, S.P. Long-term effects of metal contamination on soil microorganisms. Soil Biology and Biochemistry, v. 26, n.3, p. 421-422, 1994. 